\title{
Passifloraceae sensu stricto de Minas Gerais, Brasil
}

\author{
Passifloraceae sensu stricto from Minas Gerais, Brazil
}

Daniela Cristina Imig ${ }^{1,3}$, Michaele Alvim Milward-de-Azevedo ${ }^{2} \&$ Armando Carlos Cervi $^{\dagger}$

\begin{abstract}
Resumo
Neste trabalho são apresentadas as espécies de Passifloraceae stricto sensu do estado de Minas Gerais, Brasil. A família encontra-se representada por dois gêneros, Mitostemma, apenas com M. glaziovii e Passiflora com 52 espécies representantes dos quatro subgêneros: três espécies pertencentes a $P$. subg. Astrophea, 12 a $P$. subg. Decaloba, duas a $P$. subg. Deidamioides e 35 a $P$. subg. Passiflora, totalizando 53 espécies, das quais, quatro novas citações para o estado. São apresentadas descrições, fotos, dados de distribuição geográfica e comentários taxonômicos das espécies de Passifloraceae ocorrentes em Minas Gerais.

Palavras-chave: Passiflora subg. Astrophea, P. subg. Decaloba, P. subg. Deidamioides, P. subg. Mitostemma, P. subg. Passiflora, conservação, diversidade.
\end{abstract}

\begin{abstract}
In this work, we presented the species of Passifloraceae stricto sensu from the state of Minas Gerais, Brazil. The family is represented by two genera: Mitostemma, only with M. glaziovii, and Passiflora with 52 species in four subgenera: three species belonging to $P$. subg. Astrophea, 12 to $P$. subg. Decaloba, two to $P$. subg. Deidamioides, and 35 to $P$. subg. Passiflora, with a total of the 53 species, with four new citations for the state. Descriptions, photos, geographic distribution data, and taxonomic comments of Passifloraceae species occurring in Minas Gerais are presented.

Key words: Passiflora subg. Astrophea, P. subg. Decaloba, P. subg. Deidamioides, P. subg. Mitostemma, $P$. subg. Passiflora, conservation, diversity.
\end{abstract}

\section{Introdução}

Passifloraceae pertence à ordem Malpighiales e inclui três famílias antes tradicionalmente reconhecidas: Passifloraceae sensu stricto, contendo duas tribos, 17 gêneros e cerca de 700-750 espécies (Feuillet \& MacDougal 2007), Malesherbiaceae com um único gênero, Malesherbia Ruiz \& Pav. e 24 espécies (Gengler-Nowak 2003) e Turneraceae com 10 gêneros e cerca de 200 espécies (Arbo \& Espert 2009) tornando assim a delimitação de Passifloraceae sensu lato com 28 gêneros e cerca de 900 espécies (Tokuoka 2012; APG III 2009; Stevens 2001).

Passifloraceae sensu stricto forma um grupo monofilético (Tokuoka 2012), morfologicamente caracterizado por serem trepadeiras, providas de gavinhas, ocasionalmente arbustos ou árvores; folhas alternas, inteiras ou lobadas, raramente compostas, em geral com nectários extraflorais; flores pentâmeras com corona de filamentos e androginóforo; frutos baga ou cápsula, com sementes reticuladas, foveoladas, alveoladas ou sulcadas, envolvidas por arilo mucilaginoso (Mezzonato-Pires 2017; Milward-de-Azevedo et al. 2012; Milward-de-Azevedo 2007b; Milwardde-Azevedo \& Baumgratz 2004; Bernacci et al. 2003; Cervi 1997; Killip 1938; Imig \& Cervi 2013).

A família é predominantemente de clima tropical e subtropical ocorrendo com maior diversidade nas Américas, particularmente América Central e Sul, com menor diversidade na América do Norte, África, Ásia e Austrália e uma espécie

\footnotetext{
${ }^{1}$ Universidade Estadual Paulista “Julio de Mesquita Filho", Prog. Pós-graduação em Ciências Biológicas (Biologia Vegetal), Av. 24-A 1515, Bela Vista, Rio Claro, SP, Brazil. ${ }^{2}$ Universidade Federal Rural do Rio de Janeiro, Inst. Três Rios, Depto. Ciências do Meio Ambiente, Av. Prefeito Alberto da Silva Lavinas 1847, Centro, 25802-100, Três Rios, RJ, Brasil. michaelemilward@gmail.com

${ }^{3}$ Autor para correspondência: daniela.imig@gmail.com

$\dagger$ In memorian ao Dr. Armando Carlos Cervi, orientador de Mestrado da primeira autora e precursor deste trabalho.
} 
em Madagascar (Ulmer \& MacDougal 2004). No Brasil, ocorrem quatro gêneros: Ancistrothyrsus Harms., com apenas duas espécies (MT, AM e AC), Dilkea Mast., com quatro espécies (AC, AM, AP, PA, RO, RR e MT), Mitostemma Mast. com duas espécies (TO, BA, PI, GO, MS, MT, ES, MG e RJ) e Passiflora L. com 142 espécies, dessas 83 endêmicas e mais três variedades, distribuídas por todos os estados brasileiros (BFG 2015; Flora do Brasil 2020).

Passiflora é numericamente o maior gênero da família, com aproximadamente 525 espécies, a maioria delas encontradas nas Américas, especialmente América do Sul, onde Colômbia e Brasil formam os maiores centros de diversidade, com cerca de 240 espécies nativas (Ulmer \& MacDougal 2004; Bernacci et al. 2003). A maioria das espécies desse gênero é conhecida popularmente como maracujá e algumas possuem interesse comercial e farmacológico, sendo cultivadas em grande escala para consumo ou como ornamentais. Taxonomicamente, o gênero é subdividido em cinco subgêneros: $P$. subg. Astrophea (DC.) Mast., P. subg. Decaloba (DC.) Rchb., P. subg. Deidamioides (Harms) Killip., $P$. subg. Passiflora (Feuillet \& MacDougal 2004) e P. subg. Tetrapathea (DC.) P.S. Green, adicionado por Krosnick et al. (2009).

No estado de Minas Gerais, podem ser destacados os estudos de Passifloraceae sobre a família de Cervi (1996) para a flora de Carangola, Vitta (2006) para a flora de Grão-Mogol, Farinazzo \& Salimena (2007) para a Reserva Biológica da Represa do Grama, Milward-de-Azevedo (2007a) para o Parque Estadual de Ibitipoca, Fontes et al. (2013) para Reserva Florestal Mata do Paraíso, Mezzonato-Pires et al. (2013) para região da Serra Negra, Vitta \& Pirani (2015) para a Serra do Cipó e Moraes (2016) para o Parque Estadual da Serra do Brigadeiro.

O presente trabalho teve como objetivo contribuir para o conhecimento taxonômico e geográfico da família no estado de Minas Gerais, além de ampliar o domínio sobre a diversidade no Brasil e do atual estado de conservação das espécies, esclarecendo sua taxonomia dentro dos conceitos da moderna sistemática.

\section{Material e Métodos}

Utilizaram-se os procedimentos usuais para trabalhos taxonômicos, partindo-se do levantamento de publicações que tratam da família Passifloraceae sensu stricto. Foram feitas consultas às coleções de Passifloraceae nos herbários BHCB, BM, CESJ, G, HRB, HUFU, K, L, MBM, NY, RB, RFA, S, UB, UEC, UPCB e VIC, siglas de acordo com Holmgren et al. 1990.

As descrições foram elaboradas tomando por base as informações obtidas no exame de material de herbário, complementado, quando possível, com dados obtidos em campo. As decisões taxonômicas foram tomadas a partir da análise de tipos nomenclaturais, imagens digitalizadas e ilustrações, exemplares não-tipo, descrições originais e literatura especializada. A análise morfológica das lâminas foliares bilobadas e/ou trilobadas está de acordo com Milward-de-Azevedo \& Baumgratz (2004). As medidas de comprimento foram obtidas das nervuras medianas, já as de largura foram obtidas na porção mais larga da folha, no caso das folhas inteiras, e entre as distâncias dos ápices dos lobos laterais, no caso das folhas lobadas. As medidas de partes vegetativas e florais foram obtidas de material herborizado e/ou reidratado em água fervente. As mensurações de comprimento e largura foram obtidas pelo maior eixo apresentado por cada amostra, tendose citado nas descrições os intervalos de variação entre os menores e maiores valores encontrados. A análise de detalhes de estruturas vegetativas e reprodutivas foi realizada em estereomicroscópio.

Para o tratamento taxonômico seguiu-se a ordenação alfabética dos gêneros, subgêneros e nomes específicos.

\section{Resultados e Discussões}

Foram encontradas para família Passifloraceae sensu stricto em Minas Gerais, 53 espécies distribuídas em dois gêneros, Mitostemma Mast., com uma única espécie Mitostemma glaziovii e Passiflora com 52 espécies, sendo quatro novas citações para o estado. O gênero Passiflora encontrase representado por quatro subgêneros, sendo: $P$. subg. Astrophea com três espécies, $P$. subg. Debaloba com 12, P. subg. Deidamioides com duas e P. subg. Passiflora com 35.

\section{Chave de identificação das Passifloraceae sensu stricto ocorrentes em Minas Gerais, Brasil}

1. Flores tetrâmeras 1. Mitostemma glaziovii

1'. Flores pentâmeras 


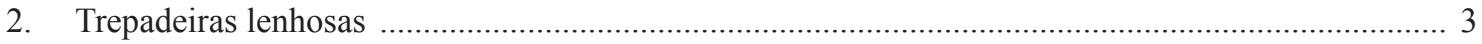

2'. Trepadeiras ou subarbustos, herbáceos ou subherbáceos ……................................................... 7

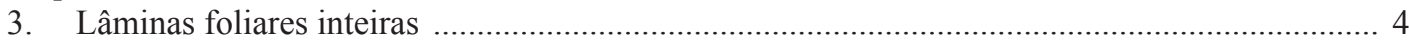

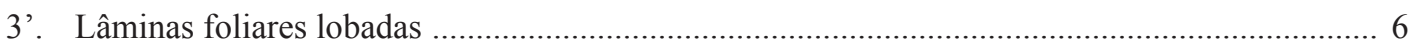

4. Flores com 7 séries de filamentos da corona .................................2. Passiflora cerradensis

4'. Flores com 2 séries de filamentos da corona

5. Flores com tubo do cálice curto-campanulado

4. Passiflora rhaminifolia

5'. Flores com tubo do cálice cilíndrico-campanulado

3. Passiflora haematostigma

6. Lâminas foliares 3-lobadas 27. Passiflora edulis

6'. Lâminas foliares 5-lobadas 29. Passiflora filamentosa

7. Subarbustos 25. Passiflora clatharata

7'. Trepadeiras 8

8. Lâminas foliares compostas .....................17. Passiflora deidamioides

8'. Lâminas foliares simples

9. Caule quadrangular

19. Passiflora alata

9'. Caule cilíndrico, subangulares ou complanados 10

10. Flores organizadas em inflorescências racemosas

18. Passiflora ovalis

10'. Flores solitárias ou aos pares

11. Pecíolos desprovidos de glândulas ........................... 12

11'. Pecíolos com glândulas ………………………......... 20

12. Lâminas foliares com oceolos ........................... 13

12'. Lâminas foliares sem oceolos ............................. 17

13. Lâminas foliares abruptamente trilobadas

15. Passiflora tricuspis

13'. Lâminas foliares trilobadas para o ápice ou 2-3 lobadas

14. Lâminas foliares trilobadas para o ápice

10. Passiflora pohlii

14'. Lâminas 2-3 lobadas 15

15. Flores com uma série de filamentos dolabriformes

11. Passiflora porophylla

15'. Flores com 2 séries de filamentos, série externa filamentos filiformes ..

16

16. Flores com ovário glabro

8. Passiflora misera

16'. Flores com ovário pubescente .

.....14. Passiflora transversalis

17. Brácteas presentes, frutos bagas 18

17’. Brácteas ausentes, frutos capsulares 19

18. Lâminas foliares inteiras 37.

Passiflora marginata

18'. Lâminas foliares

lobadas 12.

Passiflora rupestris 
19. Lâminas foliares com lobos oval-lanceolados, flores com filamentos da corona filiformes 6. Passiflora capsularis

19’. Lâminas foliares com lobos deltóides, flores com filamentos da corona liguliformes

7. Passiflora cervii

20. Flores com pétalas ausentes 13. Passiflora suberosa subsp. litoralis

20'. Flores com pétalas presentes 21

21. Estípulas lineares, linear-subuladas, falcadas ou falciformes ......................................... 22

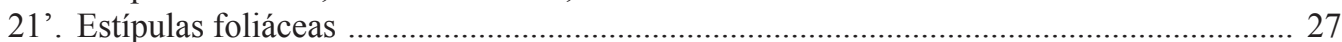

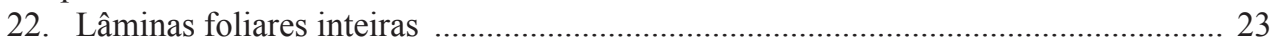

22'. Laminas foliares lobadas ou palmatipartidas .......................................................... 25

23. Flores com corona de filamentos multisseriada ....... 36. Passiflora malacophylla

23'. Flores com corona de filamentos bisseriada ...................................................... 24

24. Pecíolos com glândulas estipitadas auriculadas, lâminas foliares ovaladas a raramente oblongas ................................................5. Passiflora auriculata

24'. Pecíolos com glândulas sésseis côncavas, lâminas foliares truncadas ou curtamente trilobadas no ápice

16. Passiflora truncata

25. Lâminas foliares palmatipartidas, flores com corona de filamentos com 13 a 17 séries 24. Passiflora cincinnata

25'. Lâminas foliares 3-lobadas, flores com corona de filamentos com 2-3 séries 26

26. Pecíolos com 2 glândulas, flores com corona de filamentos com 2 séries 42. Passiflora recurva

26'. Pecíolos com 4 glândulas, flores com corona de filamentos com 3 séries 50. Passiflora trintae

27. Estípulas e/ou brácteas pinatissectas ou bipinatissectas......28

27 '. Estípulas e/ou brácteas não pinatissectas ou não bipinatissectas

28. Flores com ovário piloso.

30. Passiflora foetida var. foetida

28'. Flores com ovário glabro

29. Flores com corona de filamentos com 2 séries

21. Passiflora boticarioana

29'. Flores com corona de filamentos com 5 séries

35. Passiflora loefgrenii

30. Flores com corona de filamentos unisseriado..

31

30'. Flores com corona de filamentos com 2 séries a multisseriado

31. Estípulas oval-lanceoladas, pecíolos com 2 glândulas, sépalas das flores sem aristas ........................... 9. Passiflora morifolia

31'. Estípulas setáceas, pecíolos com 4 glândulas, sépalas das flores com aristas.

32. Lâminas inteiras 44. Passiflora setacea

32'. Lâminas lobadas .............................. 37

33. Trepadeiras velutinas 33. Passiflora hypoglauca

33'. Trepadeiras glabras ou parcialmente pilosas.............. 34

34. Estípulas reniformes a subreniformes, flores com 3-4,5 cm diâmetro ........35 
34'. Estípulas setáceas, ovaladas ou oval-lanceoladas, flores com 4,8-8,5 cm diâmetro 36

35. Brácteas ovaladas ou oblongas, flores aos pares, filamentos da corona com 3 séries

38. Passiflora mediterranea

35'. Brácteas lineares, flores solitárias, filamentos da corona com 4 séries 40. Passiflora miersii

36. Estípulas setáceas, flores com filamentos da corona multisseriados

41. Passiflora odontophylla

36'. Estípulas ovaladas a oval-lanceoladas, flores com filamentos da corona com 2 séries 46. Passiflora silvestris

37. Trepadeiras glabras 38

37'. Trepadeiras pilosas a esparsamente pilosas 47

38. Lâminas foliares palmatilobadas 22. Passiflora caerulea

38'. Lâminas 3-lobadas 39

39. Brácteas lineares

34. Passiflora kermesina

39'. Brácteas ovaladas, oval-lanceoladas, elípticas, oblongas ou setáceas 40

40. Flores com filamentos da corona com 2 a 3 séries 41

40'. Flores com filamentos da corona com 4 a 6 séries 43 41. Flores com 4-4,5 cm de diâmetro 43. Passiflora saccoi 41'. Flores com 5-15 cm de diâmetro 42. Pecíolos com 3-7 glândulas 42

42'. Pecíolos com 2 glândulas 26. Passiflora edmundoi

43. Flores com ovário densamente piloso 20. Passiflora amethystina

43'. Flores com ovário glabro 44 44. Brácteas setáceas 53. Passiflora watsoniana 44'. Brácteas ovaladas ou oblongas 45 45. Flores com 4-5 cm diâmetro 48. Passiflora tenuifila

45'. Flores com 6-9 cm diâmetro 46

46. Pecíolos com 6-8 glândulas, flores com corona de filamentos com 6 séries

28. Passiflora eichleriana

46’. Pecíolos com 2-4 glândulas, flores com corona de filamentos com 5 séries

49. Passiflora tetraden

47. Flores com corona de filamentos com 5 séries 31. Passiflora gardneri

47'. Flores com corona de filamentos com 2-3 séries 48

48. Flores com ovário glabro 52. Passiflora villosa

48'. Flores com ovário hirsuto, piloso ou tomentoso 49

49. Flores com corona de filamentos com 2 séries ... 50

49'. Flores com corona de filamentos com 3 séries ... 51

50. Flores com ovário densamente piloso.... 32. Passiflora hatschbachii 
50’. Flores com ovário tomentoso 47. Passiflora speciosa

51. Brácteas bipinatipartidas, flores com ovário hirsuto 51. Passiflora vellozii

51. Brácteas inteiras, flores com ovário densamente piloso 52 52. Estípulas reniformes, flores com 3,5-5,2 cm diâmetro 52'. Estípulas ovadas a oval-lanceoladas, flores com 2,3-3 cm diâmetro 23. Passiflora campanulata 45. Passiflora setulosa

1. Mitostemma glaziovii Mast., Journ. Bot. Brit. \& For. 21: 34, 1883.

Arbusto pouco escandente, velutino. Estípulas lineares, $0,2-0,3 \times 0,1-0,2 \mathrm{~cm}$. Folhas com pecíolos 1-1,8 cm compr., glândulas ausentes; lâminas foliares simples, oblongas, $6-9,5 \times 2,8-3,7 \mathrm{~cm}$, ápice agudo a acuminado, base aguda a atenuada, margens inteiras. Brácteas setáceas, $0,2-0,3 \times$ ca. $0,1 \mathrm{~cm}$. Pedúnculos solitários, $2-4,8 \mathrm{~cm}$ compr., articulados na porção mediana. Flores $2,5-4 \mathrm{~cm}$ diâm.; tubo do cálice curto-campanulado, 0,3-0,6 $\times 0,5-0,6 \mathrm{~cm}$; tetrâmeras; 4 sépalas oblongas, $1-1,7 \times 0,4-0,5 \mathrm{~cm} ; 4$ pétalas oblongas, $1-1,5 \times$ 0,4-0,5 cm; corona de filamentos 2 séries, série externa filiformes, $0,5-1,2 \mathrm{~cm}$ compr., série interna dolabriformes, $0,5-0,7 \mathrm{~cm}$ compr.; androginóforo 0,3-0,5cm compr.; ovário elíptico a oblongo, glabro, sulcado. Frutos bagas, elípticas a ovaladas, ca. 2 cm diâm.; sementes não vitas.

Material examinado: Caratinga, 21.IX.1984, fl. e fr., P.M. Andrade \& M.A. Lopes et al. 332 (UPCB, BHCB); 23.XI.1984, fr, P.M. Andrade et al. 560 (BHCB).

Mitostemma glaziovii é endêmica do Brasil e ocorre na Bahia e Região Sudeste, em domínio de Mata Atlântica (BFG 2015), em Minas Gerais, foi encontrada até o momento, no município de Caratinga. É facilmente distinguida das outras espécies de Passifloraceae sensu stricto ocorrentes em Minas Gerais por apresentar flores tetrâmeras, enquanto as demais espécies do gênero Passiflora são pentâmeras.

\section{Passiflora L.}

Trepadeiras, herbáceas ou lenhosas, gavinhas geralmente presentes e axilares, mais raramente árvores ou arbustos. Caules cilíndricos, angulosos ou sub-angulosos, raramente quadrangulares. Estípulas setáceas, lineares ou foliáceas persistentes ou caducas de margens inteiras, denteadas, serrilhadas ou partidas. Pecíolos normalmente providos de glândulas, nectaríferas em número, forma e posição variáveis, às vezes sem glândulas. Folhas alternas, pecioladas, simples, inteiras ou lobadas, raramente compostas, margens foliares inteiras, denteadas, serrilhadas ou glandular- serrilhadas; limbos às vezes com glândulas ocelares presentes na face abaxial. Brácteas setáceas, elípticas, ovaladas ou oblongas, pequenas ou foliáceas, persistentes ou caducas, dispersas ou verticiladas, margens inteiras, serrilhadas ou laciniadas, às vezes ausentes. Flores actinomorfas, pentâmeras, andróginas, geralmente isoladas ou aos pares, axilares, raramente em inflorescências, geralmente muito vistosas. Tubo do cálice pateliforme, campanulado, infundibuliforme ou cilíndrico. Sépalas em número de cinco, carnosas, subcoriáceas ou membranáceas, lineares, oblongas, espatuladas ou ovaladas, às vezes corniculadas ou aristadas dorsalmente, pouco abaixo do ápice. Pétalas em número de cinco, membranáceas, alternas às sépalas ou às vezes ausentes, nascendo na margem do tubo do cálice, cor branca, esverdeada, púrpuras, roxas, róseas. Corona de filamentos com uma a varias séries, constituídas de filamentos de tamanhos, formas e comprimentos distintos, podendo diferenciar-se entre as séries, cores variadas, lisas ou bandeadas. Opérculo interior e inferior à corona, membranoso, liso ou plicado, inteiro, lacerado ou filamentoso na margem, ereto ou pendente, raramente ausente. Límen geralmente presente, envolto à base do androginóforo. Anel nectarífero constituído por uma proeminência anular interior, inferior ao opérculo, às vezes ausente. Androginóforo ereto. Androceu isostêmone, cinco estames livres no extremo superior, às vezes unido na base, filetes unidos nas anteras dorsalmente (dorsifixos), anteras lineares, ovaladas ou oblongas, biloculares. Gineceu com ovário súpero, unilocular, multiovulados, rudimentos seminais anátropos, com três placentas parietais, globosos ou ovóides, raramente trígonos ou hexagonais, situado sobre o androginóforo. Estiletes três, livres ou unidos na base, cilíndricos ou clavados, estigmas captados, orbiculares ou reniformes. Fruto indeiscente tipo baga, raramente deiscente (cápsula), globosos ou ovóides, raramente fusiformes, contendo em seu interior uma polpa mucilaginosa. Sementes envolvidas por um arilo mucilaginoso, alveoladas, foveoladas, reticuladas ou sulcadas transversalmente. 
Passiflora subgênero Astrophea (DC.) Mast.

Fig. 1

Lianas lenhosas ou pequenas árvores. Caules cilíndricos, gavinhas robustas. Folhas inteiras, peninérveas, com 2 glândulas próximos a base da lâmina foliar, sésseis ou cicatriciais. Estípulas e brácteas inconspícuas. Flores campanulados a tubulares, filamentos da corona com 2 a 7 séries de filamentos. Frutos bagas com sementes reticuladas.

2. Passiflora cerradensis Sacco, III Simpósio sobre Cerrado, Edgard Blucher Ltda., São Paulo, p. 212214, 1971.

Fig. 1a,b

Trepadeiras lenhosas, glabras. Estípulas linear-subuladas, $0,1-0,2 \mathrm{~cm}$ compr. Folhas com pecíolos 1,5-3 cm compr., 1 par de glândulas opostas, sésseis e côncavas; lâminas foliares simples, ovaladas ou oval-lanceoladas, 11-16 $\times$ 3-9 cm, ápice agudo ou obtuso, base cordada ou subcordada, margens inteiras. Brácteas triangulares, $0,1-0,3 \times$ ca. $0,1 \mathrm{~cm}$, margem glandular, $3-4$ glândulas diminutas. Pedúnculos aos pares ou dispostas em ramos, 0,6-2 cm compr., ou formando pseudo-racemos, 8-45,5 cm compr., pedicelos 0,3-0,6 cm compr. Flores 3-5 cm diâm.; tubo do cálice tubular, $0,1-0,3 \times 0,2-0,4 \mathrm{~cm}$; sépalas oblongas, $1,5-2 \times 0,4-0,6 \mathrm{~cm}$; pétalas oblongas, $1,3-2 \times 0,3-0,6 \mathrm{~cm}$; corona de filamentos 7 séries, série externa dolabriformes, $1-1,8 \mathrm{~cm}$ compr., série subsequente capitados, $0,3-0,5 \mathrm{~cm}$ compr., duas séries seguintes filiformes, $0,2-0,3 \mathrm{~cm}$ compr., três últimas séries capilares, $0,1-0,2 \mathrm{~cm}$ compr.; androginóforo 2-3,5 cm compr.; ovário ovalado ou elipsoide, sulcado longitudinalmente, velutino. Frutos bagas, elípticas ou ovaladas, 4-5 ×3-3,8 cm, sulcado longitudinalmente; sementes obovadas, levemente assimétricas, $0,4-0,6 \times 0,2-0,3 \mathrm{~cm}$, testas reticuladas.

Material examinado: Formoso, 18.X.1994, M.A. da Silva et al. 3474 (IBGE, RB, UPCB).

Passiflora cerradensis é endêmica do Brasil, e possui distribuição citada para Tocantins e Região Centro-Oeste, ocorrendo em domínios de Cerrado (BFG 2015; Flora do Brasil 2020). Foi citada pela primeira vez para o estado de Minas Gerais, de acordo com Mezzonato-Pires (2017). Esta espécie diferencia-se das demais de P. subg, Astrophea por apresentar inflorescência do tipo pseudo-racemo e flores com 7 séries de filamentos da corona, além de ser considerada uma planta glabra. As ilustrações da espécie podem ser encontradas em Sacco (1971, p. 213) e MezzonatoPires (2017, p. 106, fig. 2h-m).
3. Passiflora haematostigma Mart. ex Mast., Fl. bras. 13(1): 574, tab. 108, f. 1. $1872 . \quad$ Fig. 1c-e Trepadeiras lenhosas, pilosas. Estípulas lineares, $0,2-0,3 \times 0,1-0,2 \mathrm{~cm}$. Folhas com pecíolos 1,2-3 cm compr., 2 glândulas oblongas; lâminas foliares simples, oval-lanceoladas ou oblonga-lanceoladas, 5-9 × 2,5-5 cm, ápice obtuso, raramente agudo, acuminado, base arredondada, margens inteiras a levemente onduladas. Brácteas triangulares ou setáceas, $0,3-0,6 \times$ ca. $0,1 \mathrm{~cm}$. Pedúnculos solitários, raramente aos pares, $1-1,8$ $\mathrm{cm}$ compr., pedicelos $1-1,6 \mathrm{~cm}$ compr. Flores 2,5-4,5 cm diâm.; tubo do cálice cilíndricocampanulado, $0,7-1,8 \times 0,3-0,5 \mathrm{~cm}$; sépalas oblongas $1,8-2,7 \times 0,5-0,8 \mathrm{~cm}$; pétalas oblongas a oblongo-lanceoladas $1,7-2,5 \times 0,4-0,7 \mathrm{~cm}$; corona de filamentos 2 séries, série externa dolabriformes, $1,2-1,5 \mathrm{~cm}$ compr., série interna filiformes, $0,2-0,3$ cm compr.; androginóforo 1,2-1,8 cm compr.; ovário elíptico, densamente piloso. Frutos bagas, elípticas ou ovaladas, 4-6,2 × 2-3,4 cm; sementes ovaladas, $0,3-0,5 \times 0,2-0,4 \mathrm{~cm}$, testas reticuladas. Material examinado: Barbacena, XII.2002, A. Salino \& V.A.O. Diettrich 8228 (UPCB); Barão de Cocais, 28.I.1971, H.S. Irwin et al. 29312 (NY). Belo Horizonte, 22.II.2001, F.C. Campos Neto (BHCB 57250). Betim, 5.III.1940, M. Barreto 10693 (MBM). Brumadinho, VIII.2002, P.L. Viana 772 (BHCB). Carandaí, 15.II.1946, A.P. Duarte 481 (M, S). Conceição de Ibitipoca, 1.XII.2003, Menini Neto 53 (BHCB); 3.I.2013, D.C. Imig 115 (UPCB, MBM); 9.III.2004, R.C. Forzza et al. 3055 (MBM); 2.XI.2004, E.V.S.S. Medeiros et al. 398 (MBM); 2.I.2013, D.C. Imig 117 (UPCB, MBM). Descoberto, 23.I.2001, R.C. Forzza et al. 1735 (BHCB, CESJ, MBM); 16.XI.2001, F.R.G. Salimena \& P.H. Nobre 963 (UEC, CESJ). José Brandão, 1.XII.1942, M. Magalhães 2425 (BHCB). Juiz de Fora, III.2002, D.S. Pifano \& R.M. Castro 311 (BHCB, MBM). Ouro Branco, 2.XI.2002, C.C. de Paula et al. 392 (VIC). Ouro Preto, 13.I.1972, A. Macedo 5176 (MBM, HB); 23.XII.1950, L.B. Smith 2727 (S). Pau Doce, 14.I.1942, M. Magalhães 1104 (BHCB). Santa Barbara, 12.XII.1978, H.F. Leitão et al. 9557 (BM); 15.IX.1980, R.R. Ferreira et al. 59 (VIC). Santa Maria do Salto, 25.VIII.2003, J.A. Lombardi et al. 5554 (BHCB); 21.02.2005, J.A. Lombardi et al. 4047 (BHCB). Santana do Riacho, 3.XI.1981, J.R. Pirani et al. 7687 (MBM, SPF). Serro, 25.X.1999, A.C. Cervi 6906 (MBM). Sem município, 1818, Martius 1136 (M Holotypus!).

Passiflora haematostigma é endêmica do Brasil, e distribui-se pelos estados do Amazonas, Bahia, Goiás, Mato Grosso, Minas Gerais, Pará, Paraná, Rio de Janeiro, Santa Catarina e São Paulo, ocorrendo em domínios de Floresta Amazônica, Cerrado e Mata Atlântica (BFG 2015). As ilustrações da espécie podem ser encontradas em 

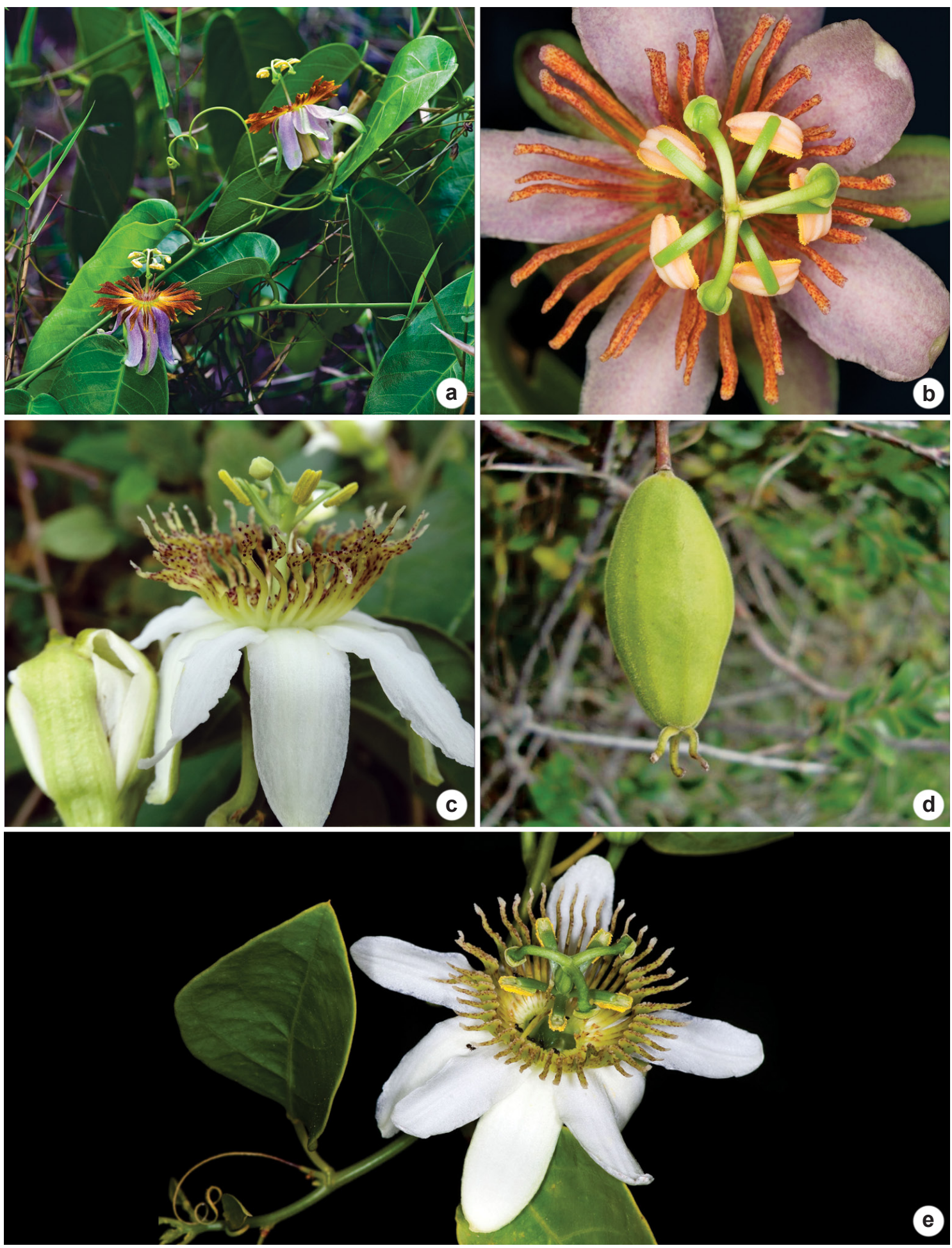

Figura 1 - Passiflora subgênero Astrophea - a,b. Passiflora cerradensis. c-e. Passiflora haematostigma. Figure 1 - Passiflora subgenus Astrophea - a,b. Passiflora cerradensis. c-e. Passiflora haematostigma. 
Masters (1872, fig. 108 I), Sacco (1980, p. 114, fig. 28), Cervi (1986, p. 25, fig. 3), Nunes \& Queiroz (2006, p. 208, fig. 10c-d), Vitta (2006, p. 10, fig. 1j), Farinazzo \& Salimena (2007, p. 829, fig. 2ac), Milward-de-Azevedo (2007a, p. 76, fig. 2i-o), Mezzonato-Pires et al. (2013, p. 126, fig. 1h-j), Vitta \& Pirani (2015, p. 31, fig. 1f-g) e MezzonatoPires (2017, p. 170, fig. 20a-g).

4. Passiflora rhamnifolia Mast., Fl. bras. 13(1): 575,1872 .

Trepadeiras lenhosas, velutinas. Estípulas lineares a setáceas, $0,2-0,3 \times 0,1-0,2 \mathrm{~cm}$. Folhas com pecíolos 1,2-3 cm compr., 2 glândulas oblongas; lâminas foliares simples, ovaladas a oval lanceoladas, 4,5-7,8 × 4,5-10,5 cm, ápice agudo mucronado, base arredondada, margens inteiras. Brácteas setáceas, $0,2-0,3 \times$ ca. $0,1 \mathrm{~cm}$, glandulares na base. Pedúnculos solitários, 1,5-2,3 cm compr., pedicelos $0,4-0,6 \mathrm{~cm}$ compr. Flores $3,5-4,2 \mathrm{~cm}$ diâm.; tubo do cálice curto-campanulado, $0,7-0,8$ $\times 0,3-0,6 \mathrm{~cm}$; sépalas oblongo-lanceoladas, $1,5-2,1$ $\times 0,4-0,6 \mathrm{~cm}$; pétalas oblongo-lanceoladas, $1,5-2$ $\times 0,4-0,5 \mathrm{~cm}$; corona de filamentos 2 séries, série externa subdolabriformes, 1-1,2 cm compr., série interna filiformes, $0,2-0,3 \mathrm{~cm}$ compr.; androginóforo 1,3-1,8 cm compr.; ovário ovóide, tomentoso. Frutos bagas, arredondadas, 3-4,2 $\times$ $3-3,8 \mathrm{~cm}$; sementes obovadas, $0,2-3,5 \times 0,2-0,3$ $\mathrm{cm}$, testas reticuladas.

Material examinado: Descoberto, 23.I.2001, R.C. Forzza et al. 1735 (CESJ, UEC, MBM, CTES, BHCB). Juiz de fora, 25.VIII.2008, A.C. Mezzonato \& L. Minini Neto 03 (CESJ); 17.III.2005, N.M. Farinazzo \& F.M. Ferreira 02 (CESJ); 21.VII.2006, V. Belchior et al. 47 (CESJ). Novo Cruzeiro, 2.XII.2004, J.R. Stehmann et al. 3702 (BHCB). Santa Maria do Salto, 21.II.2005, J.R. Stehmann et al. 4047 (BHCB, UPCB). Viçosa, 22.IX.1930, Y. Mexia 5082 ${ }^{a}(\mathrm{BM})$.

Passiflora rhamnifolia é endêmica do Brasil, ocorrendo na Bahia e Região Sudeste, em domínio de Mata Atlântica (BFG 2015; Flora do Brasil 2020). Esta espécie diferencia-se das demais espécies de $P$. subg. Astrophea por suas flores apresentarem o tubo do cálice curto-campanulado. As ilustrações da espécie podem ser encontradas em Nunes \& Queiroz (2006, p. 2015, fig. 12h-j), Moraes (2016, pág. 81, fig. 31e-i) e MezzonatoPires (2017, p. 200, fig. 29p-w).

\section{Passiflora subgênero Decaloba (DC.) Rchb.}

Fig. 2

Trepadeiras herbáceas, glabras a pilosas. Caules cilíndricos, estriados, sulcados, às vezes angulosos com 3-5 ângulos, ou complanados. Folhas com pecíolos com ou sem glândulas, lâminas foliares inteiras, bilobadas ou trilobadas, geralmente variegadas, glândulas ocelares presentes ou não. Estípulas pequenas. Brácteas 3, pequenas. Flores pateliformes, às vezes pétalas ausentes; corona de filamentos com 1-2 séries; opérculo plicado. Frutos bagas ou cápsulas; sementes reticuladas ou transversalmente sulcadas.

5. Passiflora auriculata Kunth, Nov. Gen. Sp. 2: 131. 1817.

Fig. 2a

Trepadeiras herbáceas, pubescentes. Estípulas lineares a falcadas, $0,1-0,2 \mathrm{~cm}$ compr. Folhas com pecíolos $0,5-2,5 \mathrm{~cm}$ compr., 2 glândulas estipitadas, auriculadas; lâminas foliares simples, ovaladas a raramente oblongas, $1,2-10 \times 1-5,5 \mathrm{~cm}$, ápice agudo, mucronado, base arredondada a obtusa, margens inteiras, raramente glandular denteada. Brácteas ovadas, 0,3-0,6 6 ca. $0,1 \mathrm{~cm}$. Pedúnculos solitários $0,4-1,5 \mathrm{~cm}$ compr., pedicelos $0,1-0,25 \mathrm{~cm}$ compr. Flores $2-2,5 \mathrm{~cm}$ diâm.; tubo curto-campanulado, $1-3 \times 0,6-0,7 \mathrm{~cm}$; sépalas lanceoladas, $0,8-1,3 \times 0,2-0,3 \mathrm{~cm}$; pétalas lanceoladas $0,4-0,8 \times 0,2-0,3 \mathrm{~cm}$; corona de filamentos 2 séries, série externa filiformes, $0,6-1$ $\mathrm{cm}$ compr., série interna filiformes, $0,1-0,6 \mathrm{~cm}$ compr.; androginóforo $0,3-0,5 \mathrm{~cm}$ compr.; ovário globoso a ovóide, glabro. Frutos bagas, globosas, $0,7-2 \times 0,7-1,9 \mathrm{~cm}$; sementes obovadas, $0,1-0,2$ $\times$ ca. $0,1 \mathrm{~cm}$, testas sulcadas.

Material examinado: Bandeira, 2.III.2004, J.A. Lombardi et al. 5780 (UPCB, BHCB).

Passiflora auriculata não é endêmica do Brasil. No Brasil, pode ser encontrada no Acre, Amazonas, Roraima, Rondônia, Pará, Amapá, Mato Grosso, Minas Gerais e Espírito Santo, nos domínios de Floresta Amazônica, Cerrado e Mata Atlântica (BFG 2015; Flora do Brasil 2020). É facilmente diferenciavel das outras espécies de $P$. subg. Decaloba por apresentar um par de glândulas auriculadas no pecíolo e lâminas foliares ovaladas a oblongas. As ilustrações da espécie podem ser encontradam em Milward-de-Azevedo et al. (2012, p. 10, fig. 3) e Silva et al. (2013, fig. 3d-h).

\section{Passiflora capsularis L., Sp. Pl.: 957. 1753.}

Fig. $2 b$

Trepadeiras herbáceas, moderada a densamente vilosa. Estípulas linear-subuladas a falciformes, $0,2-0,7(-1) \times$ ca. $0,1 \mathrm{~cm}$. Folhas com pecíolos 0,5-4 cm compr., glândulas ausentes; lâminas foliares simples, 2(-3)-lobadas, 0,5-6 × 

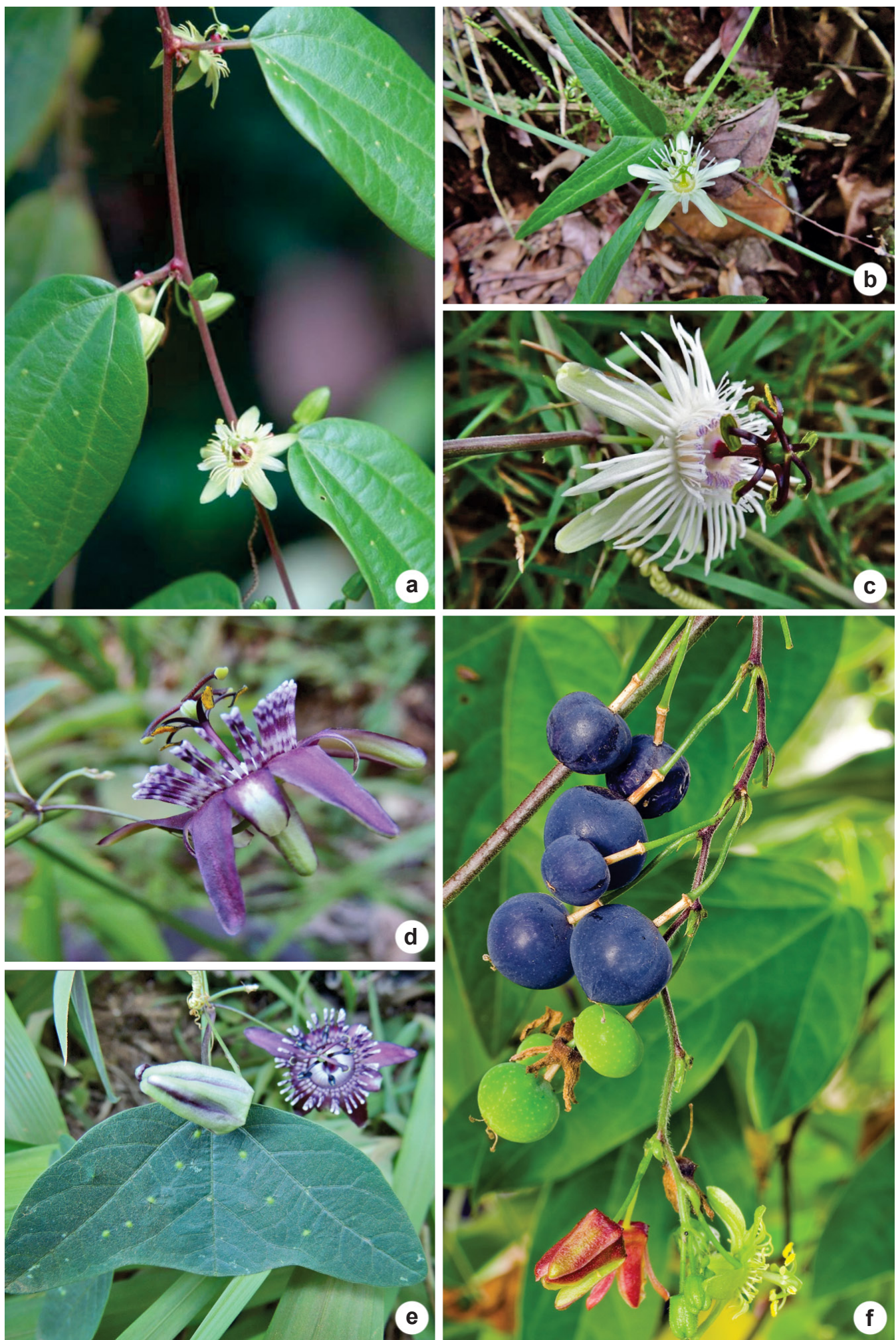

Figura 2 - Passiflora subgênero Decaloba - a. Passiflora auriculata. b. P. capsularis. c. P. polhii. d,e. P. porophylla. f. P. suberosa L. subsp. litoralis.

Figure 2 - Passiflora subgenus Decaloba - a. Passiflora auriculata. b. P. capsularis. c. P. polhii. d,e. P. porophylla. f. P. suberosa L. subsp. litoralis. 
2,7-9 cm, lobos oval-lanceolados, ápice agudo, base cordada, margem inteira, ocelos ausentes. Brácteas ausentes. Pedúnculos solitários ou raramente aos pares, 2,6-7 cm compr., pedicelos 0,2-0,5 cm compr. Flores $3-3,8 \mathrm{~cm}$ diâm.; tubo do cálice campanulado a pateliforme, $0,2-4 \times$ $0,3-0,5 \mathrm{~cm}$; sépalas oblongas, $2-3,2 \times 0,3-0,5$ $\mathrm{cm}$; pétalas oblongas $1,7-2,8 \times 0,3-0,5 \mathrm{~cm}$; corona de filamentos 1-2 séries, série externa filiformes, $0,5-1,5 \mathrm{~cm}$ compr., série interna (quando presente) capilares, $0,3-0,4 \mathrm{~cm}$ compr.; androginóforo $0,8-1$ cm compr.; ovário ovalado ou oblongo, pubérulo a glabro. Frutos cápsulas, elípticas ou fusiformes, $3-5 \times 2-3,7 \mathrm{~cm}$; sementes ovaladas $0,2-0,3 \times$ $0,1-0,3 \mathrm{~cm}$, testas sulcadas transversalmente.

Material examinado: Arantina, 3.I.2013, D.C. Imig \& D.M. Bressan 119 (MBM, UPCB). Araponga, M.F. Vieira 796 (VIC). Barroso, Y. Mexia 5402 (G). Caldas, 10.II.2009, T.M. Machado et al. 126 (CESJ); 1870, Regnell III 639 (P). Camanducaia, 1.VI.2001, J.A. Lombardi 4392 (BHCB). Catas Altas, 18.IV.05, R.C. Mota et al. 2891 (BHCB). Coimbra, 21.XI.1987, M.F. Vieira 595 (VIC). Conceição de Ibitipoca, 2.I.2013, D.C. Imig \& D.M. Bressan 108 (UPCB, MBM). Diamantina, 15.III.1970, H.S. Irwin et al. 27581 (NY); 5.II.1991, E.M. Bacariça 111 (BHCB); 19.II.1991. E. Tameirão Neto 392 (BHCB); 11.XII.1930, Y. Mexia 5402 (P, BM). Lima Duarte, 4.I.2013, D.C. Imig \& D.M. Bressan 121 (UPCB, MBM). Perdizes, 17.XII.1994, E. Tameirão Neto 1606 (BHCB). Pouso Alegre, 4.II.1973, G. Hatschbach 31190 (MBM). São Tomé das Letras, 1.I.2013, D.C. Imig \& D.M. Bressan 85 (UPCB, MBM, CTBA); 28.II.1975, G. Hatschbach 36528 (MBM). Olaria, 2.I.2013, D.C. Imig \& D.M. Bressan 109 (UPCB, MBM). Viçosa, 16.XI.1935, J.G. Kuhlmann (VIC 241); 18.XII.1958, H.S. Irwing 2276 (VIC).

Passiflora capsularis não é endêmica do Brasil. No Brasil, ocorre nos estados do Pará, Goiás, Mato Grosso do Sul, Piauí, Bahia e regiões Sudeste e Sul, em domínios de Mata Atlântica, Cerrado, Caatinga e Amazônico (BFG 2015; Flora do Brasil 2020). É relacionada com $P$. cervii, porém esta apresenta, laminas foliares com lobos mais curtos e filamentos da corona com ápice dilatado (liguliformes) (Milward-de-Azevedo et al. 2012). Os lobos das lâminas foliares em $P$. cervii são deltoides, enquanto em $P$. capsularis são ovallanceolados. As ilustrações da espécie podem ser encontradam em Standley \& Williams (1961, p. 123, fig. 14), Sacco (1980, p. 2, fig. 4), Cervi (1986, p. 29, fig. 4), Cervi (1992, p. 19, fig. 1), Cervi (1996, p. 28, fig. 3), Deginani (2001, p. 67, fig. 12), Milward-de-Azevedo \& Baumgratz (2004, p. 48, fig. 18), Milward-de-Azevedo \& Valente (2004, p. 370, fig. 1f-j), Nunes \& Queiroz (2006, p. 203, fig. 3i-k), Milward-de-Azevedo et al. (2012, p. 15, fig. 7), Mezzonato-Pires et al. (2013, p. 126, fig. 1e-f), Costa et al. (2015, p. 279, fig. 3a-d) e Moraes (2016, pág. 53, fig. 15k-n).

7. Passiflora cervii Milward-de-Azevedo, Phytotaxa 53: 1-68, 2012.

Trepadeiras herbáceas, moderada a densamente vilosa. Estípulas linear-subuladas a falciformes, $0,3-0,6 \times$ ca. $0,1 \mathrm{~cm}$. Folhas com pecíolos $0,5-3,5(-5,4) \mathrm{cm}$ compr., glândulas ausentes; lâminas foliares simples, $2-3$ lobadas, 2-6 × 3-6(-9) cm, lobos deltoides, ápice agudoapiculado, base cordada, margem inteira, ocelos ausentes. Brácteas ausentes. Pedúnculos solitários ou raramente aos pares, $1,6-7,8 \mathrm{~cm}$ compr., pedicelos $0,2-0,3 \mathrm{~cm}$ compr. Flores $3-4 \mathrm{~cm}$ diâm.; tubo do cálice campanulado a pateliforme, $0,2-4$ $\times 0,3-0,5 \mathrm{~cm}$; sépalas, oblongas, $1,5-2,5 \times 0,3-0,4$ $\mathrm{cm}$; pétalas oblongo-lanceoladas, $1-2,2 \times 0,3-0,4$ $\mathrm{cm}$; corona de filamentos uniseriada, liguliformes, 0,5-1 cm compr.; androginóforo $0,8-1 \mathrm{~cm}$ compr.; ovário elíptico a oblongo, pubescente e hispido. Frutos cápsulas, elipsoides ou ovaladas, 3-5 × 2-4 $\mathrm{cm}$; sementes elípticas $0,3-0,4 \times 0,1-0,2 \mathrm{~cm}$, testas sulcadas transversalmente.

Material examinado: Aiuruoca, 31.XII.2012, D.C. Imig 92 (MBM). Andrelandia, 31.XII.2012, D.C. Imig 103 (MBM, UPCB). Bandeira, 2.III.2004, J.A. Lombardi et al. 5772 (BHCB). Caraça, 22.II.1980, J.M. Ferrari 300 (BHCB). Mindurí, 31.XII.2012, D.C. Imig 94 (MBM). São Tomé das Letras, 1.I.2013, D.C. Imig 83 (MBM, UPCB); 1.I.2013, D.C. Imig 86 (MBM, UPCB).

Passiflora cervii é endêmica do Brasil, sendo citada para Minas Gerais e Região Sul, em domínio de Mata Atlântica (BFG 2015; Flora do Brasil 2020). Está relacionada com $P$. capsularis, que difere de $P$. cervii por apresentar os filamentos da corona filiformes e folhas com lóbulos laterais ascendentes (Milward-de-Azevedo et al. 2012). As ilustrações das espécies podem ser encontradas em Milward-de-Azevedo (2008, p. 311, fig. 1) e Milward-de-Azevedo et al. (2012, p. 20, fig. 9).

8. Passiflora misera Kunth, Nov. gen. sp. 2: 136.1817.

Trepadeiras herbáceas, pubérulas ou pilosas. Estípulas falciformes, $0,3-0,6 \mathrm{~cm}$. Folhas com pecíolos 0,5-2 cm compr., glândulas ausentes; lâminas foliares simples, 2(-3)-lobadas, 0,4-6,6× $5,1-15,1 \mathrm{~cm}$, lobos lanceolados, ápice arredondado, obtuso, ou agudo-acuminado, base cordada, margens inteiras, ocelos presentes. Brácteas linear subuladas, $0,3-0,4 \times$ ca. $1 \mathrm{~cm}$. Pedúnculos 
aos pares, $2-2,5 \mathrm{~cm}$ compr.; pedicelos $0,2-0,3$ cm compr. Flores 1,5-2,3 cm diâm.; tubo do cálice pateliforme, $0,2-0,3 \times 0,6-0,8 \mathrm{~cm}$; sépalas oblongo-lanceoladas, $0,7-1 \times 0,3-0,4 \mathrm{~cm}$; pétalas oblongo-lanceoladas $0,6-1 \times 0,2-0,3 \mathrm{~cm}$; corona de filamentos 2 séries, série externa filiformes, 0,7-1 cm compr., série interna filiformes capitados ou bilobados, $0,1-0,3 \mathrm{~cm}$ compr.; androginóforo 0,5-1 cm compr.; ovário elíptico, glabro. Frutos bagas, globosas a subglobosas, $1-1,5 \times 0,7-2 \mathrm{~cm}$; sementes obovadas ou elípticas, $0,3-0,4 \times$ ca. 0,2 $\mathrm{cm}$, testas sulcadas tranversalmente.

Material examinado: Catas Altas, 22.II.1994, $M$. Brandão 29110 (PAMG). Inconfidentes, 4.XII.1991, P. Verissimo 718 (PAMG). Paracatu, 7.I.1986, H. Saturnino 1004 (PAMG).

Passiflora misera não é endêmica do Brasil. No Brasil, ocorre no Acre, Tocantins, Alagoas, Bahia, Ceará, Maranhão, Paraíba, Pernambuco, Sergipe e regiões Centro-Oeste, Sudeste e Sul, em domínio de Mata Atlântica, Cerrado, Caatinga e Amazônico (BFG 2015; Flora do Brasil 2020). Apresenta grandes semelhanças com P. porophylla e $P$. transversalis, tornando difícil a identificação do material estéril, especialmente pela semelhança na forma da lâmina foliar. Passiflora poroplylla apresenta corona de filamentos unisseriada, com filamentos dolabriformes e ovário tomentoso e $P$. tranversalis apresenta ovário e frutos pubescentes (Milward-de-Azevedo et al. 2012). As ilustrações da espécie podem ser encontradam em Sacco (1980, p. 36, fig. 7), Cervi (1996, p. 29, fig. 4), Deginani (2001, p. 91, fig. 26), Milward-de-Azevedo \& Baumgratz (2004, p. 30, fig. 7), Nunes \& Queiroz (2006, p. 212, fig. 13a-b), Milward-de-Azevedo et al. (2012, p. 24, fig. 12a-p) e Vitta \& Pirani (2015, p. 35, fig. 2c).

9. Passiflora morifolia Mast., Fl. bras. 13(1): 555. 1872.

Trepadeiras herbáceas, pubérula. Estípulas ovaladas a oval-lanceoladas, $0,3-0,5 \times 0,2-0,4$ $\mathrm{cm}$. Folhas com pecíolos 2,5-5,3 cm compr., 2 glândulas oblongas e pedunculadas; lâminas foliares simples, 3-lobadas, 3,5-6,5 × 4,5-11 cm, lobos deltoides a ovados, ápice agudo-acuminado, base cordada a subcordada, margem denteada a denticulada. Brácteas setáceas, 0,1-0,2 cm compr. Pedúnculos ausentes; pedicelos $0,7-3 \mathrm{~cm}$ compr. Flores 3,3-5 cm diâm.; tubo do cálice pateliforme, $0,2-0,4 \times 0,7-0,9 \mathrm{~cm}$; sépalas oblongas $1-2,2 \times$ $0,3-0,5 \mathrm{~cm}$; pétalas oblongo-lanceoladas $1-2 \times$ $0,3-0,4 \mathrm{~cm}$; corona de filamentos unisseriada, filiformes $0,8-1,2 \mathrm{~cm}$ compr.; androginóforo 0,5-0,8 cm compr.; ovário ovóide a subgloboso, piloso. Frutos bagas, globosas a subglobosas, raramente ovoide, 2,5-3,8 × 1,1-4 cm; sementes obovaladas, $1,5-2 \times 0,3-0,5 \mathrm{~cm}$, testas reticuladas. Material examinado: Caldas-Alfenas, IV.1869, Regnell III 1701 (S). Juiz de Fora, I.1970, L. Krieger 7991 (MBM, CESJ). Marliéria, Parque Estadual do Rio Doce, 30.III.1996, J.A. Lombardi et al. 1193 (BHCB). Patrimônio, 18.V.1941, J.E. Oliveira 464 (BHCB).

Passiflora morifolia não é endêmica do Brasil. No Brasil, pode ser encontrada no Mato Grosso, Minas Gerais, São Paulo e nos estados da Região Sul, nos domínios de Cerrado e Mata Atlântica (BFG 2015; Flora do Brasil 2020). É facilmente diferenciavel das outras espécies de $P$. subg. Decaloba por apresentar duas glândulas oblongas opostas e pedunculadas no pecíolo e lâminas foliares com margem denteada ou denticulada. As ilustrações da espécie podem ser encontradas em Masters (1872, fig. 112), Sacco (1980, p. 16, fig. 2), Deginani (2001, p. 99, fig. 30), Milwardde-Azevedo \& Baumgratz (2004, p. 45, fig. 16) e Milward-de-Azevedo et al. (2012, p. 30, fig. 15).

10. Passiflora pohlii Mast., Fl. bras. 13(1): 586. 1872. Fig. 2c

Trepadeiras herbáceas, moderada a densamente velutinas. Estípulas linear subuladas a falciformes, $0,3-0,5 \times$ ca. $0,1 \mathrm{~cm}$. Folhas com pecíolos $0,5-3,5 \mathrm{~cm}$ compr., glândulas ausentes; lâminas foliares simples, obovadas, trilobadas no ápice, 2-3,5 × 2,7-10 cm, ápice arredondadomucronado, base subcuneada ou arredondada, margens inteiras, oceolos presentes. Brácteas linear-subuladas, $0,3-0,6 \times$ ca. $0,1 \mathrm{~cm}$. Pedúnculos solitários ou aos pares, raramente formando pseudo-racemos, $1-2,5 \mathrm{~cm}$ compr., articuladas na porção mediana; pedicelo $0,1-0,2 \mathrm{~cm}$ compr. Flores 1,5-3 cm diâm.; tubo do cálice pateliforme $0,2-0,3$ cm compr.; sépalas oblongas, $0,9-1,2 \times 0,4-0,5$ $\mathrm{cm}$; pétalas oblongas a oblongo-lanceoladas $0,7-1$ $\times 0,3-0,4 \mathrm{~cm}$; corona de filamentos 2 séries, série externa filiformes, $0,5-1 \mathrm{~cm}$ compr., série interna filiformes, 0,2-0,4 cm compr.; androginóforo 0,6-1 $\mathrm{cm}$ compr.; ovário elíptico, glabro ou pubérulo. Frutos bagas, globosas a subglobosas, $0,8-1,2 \times$ $0,8-1,2 \mathrm{~cm}$; sementes elípticas, $0,25-0,4 \times 0,1-0,3$ $\mathrm{cm}$, testas transversalmente sulcadas.

Material examinado: M. Claussen 376 (S); 16.I.1971, H.S. Irwin et al. 30450 (NY). Belo Horizonte, Lagoa da Pampulha, 19.IX.1945, O. Willian \& V. Assis 7577 (S); 13.IX.1995, J.A. Lombardi et al. 923 (BHCB); 23.II.1990, E. Tameirão Neto 01 (UPCB, BHCB). Bocaíuva, 
4.X.1978, M.R. Coons 78-1078 (VIC). Congonhas do Campo, 11.X.1962, G. Pabst 7068 (MBM, RFA). Joaquim Felício, 14.IV.1996, G. Hatschbach et al. 64695 (MBM). Lagoa Santa, 12.IX.1932, M. Barreto 878 (BHCB). Lossance, 20.X.1999, A.C. Cervi et al. 6902 (MBM). Montes Claros, 6.X.1978, M.R. Coons 78-1131 (VIC). Pirapora, 13.IV.1996, G. Hatschbach et al. 64604 (MBM). São Gonçalo do Abaeté, 11.III.1982, G. Hatschbach et al. 44642 (MBM). São João Del Rei, 16.XI.1985, L. Krieger 20969 (UFJF, UPCB). Sete Lagoas, 26.IX.1996, J.A. Lombardi et al. 1384 (BHCB). Uberlândia, 13.IV.1981, G. Hatschbach et al. 43864 (MBM). Várzea da Palma, 25.X.1999, A.C. Cervi et al. 6900 (MBM).

Passiflora pohlii não é endêmica do Brasil. No Brasil, ocorre na Bahia, Minas Gerais, Espírito Santo, São Paulo e na Região Centro-Oeste, em domínio de Cerrado e Mata Atlântica (BFG 2015; Flora do Brasil 2020). É uma espécie afim de $P$. porophylla, porém esta difere-se por apresentar lâminas foliares 2-3 lobadas e corona de filamentos unisseriada e filamentos dolabriformes. Também demonstra afinidade com $P$. rupestris, diferindo-se por não apresentar oceolos nas laminas foliares. As ilustrações da espécie podem ser encontradas em Cervi (1986, p. 44, fig. 9), Imig \& Cervi (2013), Milward-de-Azevedo \& Baumgratz (2004, p. 41, fig. 14), Nunes \& Queiroz (2006, p. 215, fig. 16f-g), Milward-de-Azevedo et al. (2012, p. 18, fig. 36) e Vitta \& Pirani (2015, p. 35, fig. 2f-g).

11. Passiflora porophylla Vell., Fl. Flum. 9, tab. 82,1831 .

Fig. 2d,e

Trepadeiras herbáceas, inteiramente glabra ou levemente pubérula. Estípulas linear-subuladas 0,15-0,25 cm compr. Folhas com pecíolos 2-4,5 cm compr., glândulas ausentes; lâminas foliares simples, 2-3-lobadas, 1,5-2,5(-4,5) × 1,3-3,4(-9) $\mathrm{cm}$, lobos laterais oblongos a oblongo-lanceolados, ápice obtuso a arredondado, base subpeltada, margens inteiras, oceolos presentes. Brácteas setáceas, $0,2-0,3 \times 0,1-0,2 \mathrm{~cm}$. Pedúnculos aos pares, 3-4,5 cm compr.; pedicelo 0,3-0,4 cm compr. Flores 3,5-4,5 cm diâm.; tubo do cálice pateliforme, $0,5-0,8 \times 0,3-0,5 \mathrm{~cm}$; sépalas oblongo-lanceoladas, $1,5-1,7 \times 0,4-0,5 \mathrm{~cm}$; pétalas oblongo-lanceoladas, 1,3-1,6 × 0,4-0,5 $\mathrm{cm}$; corona de filamentos em uma única série, dolabriformes, 0,5-0,7 cm compr.; androginóforo 0,7-1 cm compr.; ovário elipsoide a oblongo, piloso. Frutos bagas, globosas, 1,5-2,3 × 1,5-2,3 $\mathrm{cm}$; sementes obovadas, $0,3-0,4 \times 0,1-0,2 \mathrm{~cm}$, testas transversalmente sulcadas.

Material examinado: Saint Hilaire B1 661 (L). Arantina, 3.I.2013, D.C. Imig 113 (UPCB). Araponga, 4.IV.1986,
M.F. Vieira et al. 355 (UPCB, VIC). Bandeira, 1.III.2004, J.A. Lombardi et al. 5746 (UPCB, BHCB). Caeté, Serra da Piedade, 13.I.1971, H.S. Irwin et al. 30290 (NY); 10.IV.1996, J.A. Lombardi 1253 (BHCB); 6.III.2002, J.A. Lombardi 4629 (BHCB, UPCB). Catas Altas, Serra do Caraça, 18.IV.2005, R.C. Mota at al. 2890 (BHCB). Cristália, 10.II.1991, G. Hatschbach et al. 55028 (MBM). Grão Mogol, 21.III.1980, G. Hatschbach 42848 (MBM). Juiz Fora, Morro do Imperador, 11.I.2002, Pifano et al. 251 (CESJ, UEC, UPCB, MBM). Novo Cruzeiro, 2.X.2004, Stehmann at al. 3531 (ICB, BHCB); 2.XII.2004, Stehmann at al. 3666 (BHCB, UPCB). Pedralva, Serra da Pedra Branca, 28.IV.2004, J.P. Braga 180 (CESJ, UPCB). Pocinhos de Rio Verde, 23.I.2009, T.M. Machado et al. 111 (CASJ). São João da Chapada, 28.III.1970, H.S. Irwin et al. 28473 (NY). Teófilo OtoniPadre Paraiso, 8.III.1977, G.J. Shepherd et al. 4376 (MBM). Viçosa, 7.VI.1935, J.G. Kuhlmann (VIC 242)

Passiflora porophylla é endêmica do Brasil, sendo citada para a Bahia e regiões Sudeste e Sul, em domínio de Mata Atlântica (BFG 2015; Flora do Brasil 2020). É semelhante a $P$. pohlii, porém esta difere-se por apresentar corona de filamentos bisseriada, com filamentos filiformes. As ilustrações da espécie podem ser encontradas em Vellozo (1831, fig. 82), Masters (1872, fig. 111), Sacco (1980, p. 30, fig. 5), Milward-de-Azevedo \& Baumgratz (2004, p. 37, fig. 12), Nunes \& Queiroz (2006, p. 215, fig. 16c-e), Vitta (2006, p. 10, fig. 1hi), Milward-de-Azevedo et al. (2012, p. 38, fig. 20), Mezzonato-Pires et al. (2013, p. 131, fig. 2d), Vitta \& Pirani (2015, p. 35, fig. 2d-e) e Moraes (2016, pág. 81, fig. 31a-d). Foi avaliada pelo CNCFlora (2016) como LC (menos preocupante), de acordo com os critérios da IUCN.

12. Passiflora rupestris Bernacci, Mezzonato \& Salimena, Systematic Botany 39(2): 517. 2014.

Trepadeiras herbáceas, pubérulas. Estípulas falciformes $0,15-0,2 \times$ ca. $0,5 \mathrm{~cm}$. Folhas com pecíolos 1-1,2 cm compr., glândulas ausentes; lâminas foliares simples, obtriangulares, 3-lobadas para o ápice, 1,5-2,9 × 1,3-2,2 cm, ápice agudoapiculado, base aguda, margens inteiras, oceolos ausentes. Brácteas setáceas, 0,2-0,25 × ca. 0,05 $\mathrm{cm}$. Pedúnculos solitários ou aos pares, ca. $4 \mathrm{~cm}$ compr.; pedicelo 1,5-1,7 cm compr. Flores ca. 2,5 cm diâm.; tubo do cálice pateliforme; sépalas oblongo-lanceoladas, ca. 1,2 × 0,4 cm; pétalas oblongo-lanceoladas, 0,9-1 × ca. 0,4 cm; corona de filamentos 2 séries, série externa filiformes, ca. $1,2 \mathrm{~cm}$ compr., série interna linear-capitados, ca. 0,7 cm compr.; androginóforo ca. 0,7 cm compr.; ovário globoso, glabro. Frutos bagas, globosas, 
1,5-1,7 × 1,5-1,7 cm; sementes obovadas, ca. 0,4 $\times 0,3 \mathrm{~cm}$, testas sulcadas transversalmente.

Material examinado: Rio Preto, Serra Negra, trilha para o Ninho da Égua, 27.I.2007, L. Menini Neto et al. 284 (holótipo: CESJ).

Passiflora rupestris é endêmica do Brasil, ocorrendo até o momento somente em Minas Gerais, em vegetação de campo rupestre. É semelhante a $P$. pohlii, porém esta difere-se por apresentar lâminas foliares sem oceolos. A ilustração da espécie pode ser encontrada em Bernacci et al. (2014, fig. 1).

13. Passiflora suberosa L. subsp. litoralis (Kunth) Port.-Utl. ex M.A.Milward-de-Azevedo, Baumgratz \& Gonçalves-Esteves, Phytotaxa 53: 47. 2012.

Fig. $2 f$

Trepadeiras herbáceas, esparso a densamente velutinas. Estípulas 0,4-0,9 × 0,1-0,3 cm, linear subuladas. Folhas com pecíolos $1-3 \mathrm{~cm}$ compr., 2 glândulas curto-estipitadas, ca. 0,1 cm compr.; lâminas foliares simples, ovalados, oval-lanceoladas, ou (2-)3-lobadas, 4-11 × 3-11 cm, ápice agudo a agudo-apiculado, base truncada a levemente arredondada, subpeltada, margens inteiras. Brácteas triangulares, $0,2-0,3 \times 0,1-0,2 \mathrm{~cm}$. Pedúnculos aos pares $0,5-2 \mathrm{~cm}$ compr., pedicelos $0,2-0,5 \mathrm{~cm}$ compr. Flores 1-2,3 cm diâm.; tubo de cálice pateliforme, $0,2-0,3 \times 0,4-0,5 \mathrm{~cm}$; sépalas oblongas, $0,6-1,3 \times$ $0,2-0,6 \mathrm{~cm}$; pétalas ausentes; corona de filamentos 2 séries, série externa filiformes a levemente subulados, 0,3-0,5 cm compr., série interna filiformes, capitados no ápice, $0,2-0,3 \mathrm{~cm}$ compr.; androginóforo $0,4-0,7 \mathrm{~cm}$ compr.; ovário ovoide a subgloboso, glabro ou pubescente. Frutos bagas, globosas a subglobosas, $0,6-1,2 \times 0,6-1,2 \mathrm{~cm}$; sementes obovadas assimétricas $0,2-0,3 \times 0,1-0,2$ $\mathrm{cm}$, testas foveoladas.

Material examinado: Aiuruoca, 29.XII.2012, D.C. Imig \& D.M. Bressan 98 (UPCB, MBM); 30.XII.2012, D.C. Imig \& D.M. Bressan 99 (UPCB). Baependi, Toca dos Urubus, 10.X.2004, F.M. Ferreira \& C. Matozinhos 753 (CESJ). Barroso, Mata do Baú, 20.X.2001, R.C. Forzza et al. 1914 (CESJ). Caldas, Pocinhos do Rio Verde, Pedreira Granito Marrom Imperial, 10.II.2009, T.M. Machado et al. 134 (BHCB). Lima Duarte, 1.I.2013, D.C. Imig \& D.M. Bressan 107 (UPCB, CTBA). Pains, Fazendo Amargoso, 8.V.2004, P.H.A. Melo et al. 1191 (BHCB). Santa Rita do Sapacaí, 19.II.1996, O.S. Ribas 1304 (MBM). Santana do Garambeu, Trecho do Alto Rio Grande, 6.VI.2001, A. Salino \& R.C. Mota 6953 (BHCB). São Tomé das Letras, 1.I.2013, D.C. Imig \& D.M. Bressan 98 (UPCB). Teixeiras, 24.IV.1999, G.E. Valente 425 (VIC). Viçosa, Campus da UFV, margem da lagoa, 27.VII.2004, P.H.A. Melo 1365 (BHCB).
Passiflora suberosa não é endêmica do Brasil. Ocorre em Roraima, Alagoas, Bahia, Ceará, Maranhão, Paraíba, Pernambuco, Rio Grande do Norte, Sergipe e regiões Centro-Oeste, Sudeste e Sul, em domínios de Mata Atlântica, Amazônia, Cerrado e Caatinga (BFG 2015; Flora do Brasil 2020). Apresenta grande variação na forma da lâmina foliar (inteiras a 3-lobadas), com lóbulos superficiais ou profundos. Distingue-se das demais espécies de $P$. subg. Decaloba, por não apresentar pétalas nas flores. As ilustrações da espécie podem ser encontradam em Sacco (1980, p. 21, fig. 3), Cervi (1996, p. 26, fig. 1), Deginani (2001, p. 105, fig. 34), Imig \& Cervi (2014 p.89), Milward-deAzevedo \& Baumgratz (2004, p. 23, fig. 3), Nunes \& Queiroz (2006, p. 220, fig. 19c-d) e Milward-deAzevedo et al. (2012, p. 48, fig. 26).

14. Passiflora transversalis Milward-de-Azevedo, Brittonia 60(4): 314, 2008.

Trepadeiras herbáceas, pubérulas. Estípulas linear subuladas a falciformes, $0,1-0,3 \mathrm{~cm}$ compr. Folhas com pecíolos $0,5-2,8 \mathrm{~cm}$ compr., glândulas ausentes; lâminas foliares simples 2-3-lobadas, 0,5-4,3 × 3,6-15 cm, lobos oblongos-lanceolados, ápice agudo-apiculado, base arredondada a subcordada, margens inteiras, ocelos presentes. Brácteas linear-subuladas, $0,3-0,4 \times$ ca. $0,1 \mathrm{~cm}$. Pedúnculos solitários ou aos pares, $1,8-2 \mathrm{~cm}$ compr.; pedicelos $0,1-0,2 \mathrm{~cm}$ compr. Flores 2-2,5 cm diâm.; tubo do cálice pateliforme, $0,2-0,3 \times 0,4-0,5 \mathrm{~cm}$; sépalas oblongas a oblongolanceoladas, $1-1,5 \times 0,3-0,5 \mathrm{~cm}$; pétalas oblongas a oblongo-lanceoladas, $0,6-1 \times 0,2-0,3 \mathrm{~cm}$; corona de filamentos 2 séries, série externa filiformes, $0,5-1,4 \mathrm{~cm}$ compr., série interna capilares, $0,1-0,3$ cm compr.; androginóforo $0,5-1,2 \mathrm{~cm}$ compr.; ovário eliptico, pubescente. Frutos bagas, globosas a subglobosas, $0,8-1,5 \times 0,6-1,4 \mathrm{~cm}$; sementes elípticas a obovadas, $0,1-0,2 \times$ ca. $0,2 \mathrm{~cm}$, testas sulcadas transversalmente.

Material examinado: Itajuba, 27.I.1968, A. Castellanos 26911 (HB); 27.I.1982, A. Castellanos 26908 (HB). Juiz de Fora, 14.III.1945, E. Pires 1840 (SP). Pouso Alegre, 28.IV.1927, F.C. Hoehne 19242 (SP, SPF).

Passiflora transversalis é endêmica do Brasil, ocorrendo no Ceará, Minas Gerais, São Paulo, Paraná, Santa Catarina e Rio Grande do Sul, em domínios de Mata Atlântica e Cerrado (BFG 2015; Flora do Brasil 2020). É uma espécie relacionada com $P$. misera, mas difere-se principalmente pela pilosidade de ovário, $P$. tranversalis apresenta ovário e frutos pubescentes e em $P$. misera tais 
estruturas são glabras. As ilustrações da espécie podem ser encontradas em Milward-de-Azevedo (2008, p. 315, fig. 3) e Milward-de-Azevedo et al. (2012, p. 54, fig. 28).

15. Passiflora tricuspis Mast., Fl. bras. 13(1): 587. 1872 .

Trepadeiras herbáceas, glabra a parcialmente pubérulas. Estípulas lineares a falciformes, 0,2-0,3 cm compr. Folhas com pecíolos 1-2,5 cm compr., glândulas ausentes; lâminas foliares simples, abruptamente trilobadas, 4,4-11,6 $\times$ 4,6-12 cm, ápice agudo-acuminado, base cuneada a subcuneada, margens inteiras, ocelos presentes. Brácteas linear-subuladas, 0,3-0,4 × ca. $0,1 \mathrm{~cm}$. Pedúnculos aos pares, 1,8-2,3(-3) cm compr.; pedicelos 0,2-0,3 cm compr. Flores 2,3-3,5 cm diâm.; tubo do cálice pateliforme, 0,2-0,3 × 0,6$0,8 \mathrm{~cm}$; sépalas oblongas a oblongo-lanceoladas 0,8-1,3 $\times 0,3-0,4 \mathrm{~cm}$; pétalas oblongas a oblongolanceoladas, $0,6-1,2 \times 0,3-0,4 \mathrm{~cm}$; corona de filamentos 2 séries, série externa filiformes, 0,7-1,4 cm compr., série interna filiformes, com ápice capitado ou bilobado, 0,1-0,4 cm compr.; androginóforo 0,5-1 cm compr.; ovário subgloboso, glabro. Frutos bagas, globosas a subglobosas, 1,3-1,8 × 1,3-1,8 cm; sementes elípticas, $0,3-0,4 \times$ ca. $0,2 \mathrm{~cm}$, testas sulcadas transversalmente.

Material examinado: Pitangui, estrada para Pintangui, 1.V.2001, F. Campos Neto (BHCB 62256); 9.X.2001, F. Campos Neto (BHCB 64897).

Passiflora tricuspis não é endêmica do Brasil. No Brasil, ocorre no Acre, Amazonas, Pará, Bahia, Ceará, Piauí, Minas Gerais, São Paulo, Paraná e na Região Centro-Oeste, em domínios de Mata Atlântica, Amazônia e Cerrado (BFG 2015; Flora do Brasil 2020). Esta espécie difere das demais por apresentar as lâminas foliares visivelmente trilobadas. As ilustrações da espécie podem ser encontradam em Sacco (1980, p. 40, fig. 8), Cervi (1986, p. 41, fig. 8), Milward-deAzevedo \& Baumgratz (2004, p. 34, fig. 10) e Milward-de-Azevedo et al. (2012, p. 57, fig. 30). Foi avaliada pelo CNCFlora (2016) como LC (menos preocupante), de acordo com os critérios da IUCN.

16. Passiflora truncata Regel, Ann. Sci. Nat. IV. Bot. 12: 378. 1859.

Trepadeiras herbáceas, pubérulas. Estípulas linear-setáceas, ca. 0,1 cm compr. Folhas com pecíolos 1-2,5 cm compr., 2 glândulas côncavas, sésseis; lâminas foliares simples, truncadas ou curtamente trilobadas no ápice, 3-5,5 × 3,3-8 $\mathrm{cm}$, ápice agudo ou truncado, base arredondada, subpeltada, margens inteiras, oceolos presentes. Brácteas setáceas, $0,1-0,2 \times$ ca. $0,1 \mathrm{~cm}$. Pedúnculos aos pares, 1,3-1,7 cm compr.; pedicelo 0,1-0,2 cm compr. Flores 1,5-2,2 cm diâm.; tubo do cálice pateliforme, $0,3-0,6 \times 0,2-0,4 \mathrm{~cm}$; sépalas oblongolanceoladas, $0,8-1 \times 0,2-0,3 \mathrm{~cm}$; pétalas oblongolanceoladas, $0,5-0,8 \times 0,2-0,3 \mathrm{~cm}$; corona de filamentos 2 séries, série externa liguliformes, 0,3 $0,4 \mathrm{~cm}$ compr., série interna filiformes, capitados no ápice, 0,1-0,2 cm compr.; androginóforo 0,2-0,4 cm compr.; ovário elipsóide a oblongo, densamente pubérulo. Frutos bagas, globosas, 1,5-3 × 1,5-3 cm; sementes ovaladas, $0,3-0,4 \times 0,2-0,3 \mathrm{~cm}$, testas transversalmente sulcadas.

Material examinado: Congonhas do Campo, 11.X.1962, G. Pabst $7068 b$ (MBM).

Passiflora truncata é endêmica do Brasil, ocorrendo no Rio de Janeiro, São Paulo, Paraná e Santa Catarina, em domínio de Mata Atlântica (BFG 2015; Flora do Brasil 2020), sendo a primeira vez citada para Minas Gerais. É caracterizada por apresentar laminas foliares truncadas no ápice ou então superficialmente trilobadas, coriáceas. As ilustrações da espécie podem ser encontradas em Sacco (1980, p. 13, fig. 1), Milward-de-Azevedo \& Valente (2004, p. 373, fig. 3), Milward-deAzevedo \& Baumgratz (2004, p. 27, fig. 5) e Milward-de-Azevedo et al. (2012, p. 60, fig. 32).

\section{Passiflora subgênero Deidamioides (Harms) Killip}

Trepadeiras lenhosas, raramente herbáceas, glabras. Caules cilíndricos, gavinhas às vezes bifurcadas ou com discos adesivos apicais; folhas inteiras ou compostas (3-9 folíolos em duas espécies), nunca variegadas, glândulas ocelares ausentes ou nectários inconspícuos próximo a margem; frequentemente com 2 nervuras laterais próximo a base da lâmina; estípulas diminutas; 2 nectários peciolares, sésseis, cicatricionais ou ligeiramente estipitados. Pedúnculos 1-2 flores ou suportadas pela gavinha; brácteas muito pequenas; flores alvas, branco esverdeadas com corona de filamentos branco a amarelo ou amarelo com alaranjado, não bandeados de vermelho e púrpura, exceto em P. ovalis Vell.; tubo do cálice pateliforme ou campanuado; opérculo mais ou menos plicado; frutos esverdeados amarelos ou alaranjados; sementes reticuladas. Passiflora ovalis apresenta em suas flores 4 estiletes e 4 carpelos. 
17. Passiflora deidamioides Harms, Repert. Sp. Nov. 19:57, 1923.

Trepadeiras sublenhosas, glabras. Estípulas lineares, $0,3-0,5 \times$ ca. $0,1 \mathrm{~cm}$. Folhas com pecíolos 1,5-3,7 cm compr., 4 glândulas orbiculares sésseis, peciólulos $0,3-0,8 \mathrm{~cm}$ compr.; lâminas foliares tricompostas, folíolos oblongo-lanceoladas ou elípticos, folíolos medianos 5-10 × 1,8-3 cm, folíolos laterais 4,5-9 × 1,8-3 cm, ápice agudo a obtuso, mucronado, base aguda a oblíqua, margens inteiras. Brácteas linear-subuladas, 0,1-0,2 $\mathrm{cm}$ compr. Pedúnculos originários da gavinha, trifurcados no ápice, sendo dois pedúnculos laterais terminados em flores e o central terminado em gavinha, porção $2-3 \mathrm{~cm}$ compr., robustos; pedicelo $0,5-0,9 \mathrm{~cm}$ compr. Flores $3,8-5,5 \mathrm{~cm}$ diâm.; tubo do cálice curto-campanulado, $0,4-0,7$ $\times 0,5-1 \mathrm{~cm}$; sépalas oblongo-lanceoladas $1,5-2,4$ $\times 0,5-0,8 \mathrm{~cm}$; pétalas oblongo-lanceoladas, $1,5-2,2$ $\times 0,4-0,6 \mathrm{~cm}$; corona de filamentos em múltiplas séries justapostas, séries externas filiformes, 1-2 cm compr., séries intermediárias, filiformes, 0,4-0,6 cm compr., séries internas capilares, $0,1-0,2 \mathrm{~cm}$ compr.; androginóforo $0,8-1,5 \mathrm{~cm}$ compr.; ovário oblongo a elíptico, glabro, sulcado longitudinalmente. Frutos bagas, oblongos a elípticas, 2,8-3,5 × 1,8-2,5 cm; sementes oblongas a ovaladas, 4-5 × 2-2,2 $\mathrm{mm}$, testas reticuladas.

Material examinado: Conceição de Ibitipoca, 13.V.1970, L. Krieger 8661 (UPCB, CESJ); 2.I.2013, D.C. Imig 124 (MBM, UPCB).

Passiflora deidamioides é endêmica do Brasil, ocorrendo em Minas Gerais, Rio de Janeiro e São Paulo, em domínio de Mata Atlântica e Cerrado (BFG 2015; Flora do Brasil 2020). É uma espécie facilmente diferenciavel das outras espécies ocorrentes em Minas Gerais, pois é a única com folhas compostas e a única com gavinhas trifurcadas, cujas flores se desenvolvem sobre gavinha. As ilustrações da espécie podem ser encontradam em Bernacci et al. (2003, p. 263, fig. 1d-g) e Milwardde-Azevedo (2007a, p. 76, fig. 2a-h).

18. Passiflora ovalis Vell., Fl. Flum. 9: tab. 75. 1831.

Trepadeiras lenhosas, glabras. Estípulas setáceas $0,4-0,7 \mathrm{~cm}$ compr. Folhas com pecíolos 1,2-2 cm compr., 2 glândulas oblongas, sésseis; lâminas foliares simples, elípticas a oblongaslanceoladas, 7-12 × 2,5-3,5 cm, ápice agudo a atenuado, apiculado, às vezes assimétricas, base aguda a cuneada, margens inteiras. Brácteas setáceas, $0,1-0,2 \mathrm{~cm}$ compr. Inflorescências racemosas; pedúnculos solitários ou aos pares, 1,5-2,3 cm compr.; pedicelos $0,4-0,5 \mathrm{~cm}$ compr. Flores 5,5-8,5 cm diâm.; tubo do cálice curtocampanulado, $1-1,5 \times 0,5-0,7 \mathrm{~cm}$; sépalas oblongo-lanceoladas 2,7-4 × 0,4-0,8 cm; pétalas oblongas a oblongo-lanceoladas $2,4-3,6 \times 0,3-0,7$ $\mathrm{cm}$; corona de filamentos 2 séries, filiformes, às vezes bifurcados no ápice, série externa $0,8-1,2$ cm compr., série interna $0,4-0,6 \mathrm{~cm}$ compr.; androginóforo 2,2-2,8 cm compr.; ovário oblongo a elíptico, glabro. Frutos bagas, elípticas ou ovaladas, 6-10 × 3-6 cm; sementes obovaladas, $0,6-0,8 \times$ $0,2-0,4 \mathrm{~cm}$, testas foveoladas.

Material examinado: Bandeira, 1.III.2004, J.A. Lombardi et al. 5726 (BHCB, UPCB). Santa Maria do Salto, 24.VIII.2003, J.A. Lombardi et al. 5496 (BHCB); 10.X.2003, A. Salino et al. 9221 (BHCB); 8.III.2004, J.A. Lombardi et al. 5928 (BHCB).

Passiflora ovalis é endêmica do Brasil, ocorrendo no Rio de Janeiro e São Paulo, em domínio de Mata Atlântica (BFG 2015; Flora do Brasil 2020). É citada pela primeira vez para o estado de Minas Gerais. Esta espécie difere das demais por apresentar inflorescências racemosas e flores com 4 estiletes e 4 carpelos. A ilustração da espécie pode ser encontrada em Vellozo (1831, fig. 75).

Passiflora subgênero Passiflora L.

Fig. 3

Trepadeiras a lianas. Caules cilíndricos à quadrangulares. Estípulas foliáceas, Folhas inteiras à 3-7-lobadas, pecíolos com ou sem glândulas, lâminas foliares com ou sem glândulas, entre os lobos foliares ou nas margens. Flores grandes e geralmente vistosas com corona de filamentos com 1-20 séries de filamentos, opérculo nunca plicado. Frutos grandes com sementes reticuladas.

19. Passiflora alata Curtis, Bot. Mag. 2: tab. 66, 1788.

Trepadeiras lenhosas, glabras. Caules quadrangulares, ângulos alados. Estípulas elípticas ou oval-lanceoladas $0,8-1,7(-2) \times 0,2-0,4(-0,5)$ $\mathrm{cm}$. Folhas com pecíolos 1,8-4 cm, 2-4 glândulas orbiculares, $0,1-0,2 \mathrm{~cm}$; lâminas foliares simples, ovaladas a oblongas, 7-13 × 6-10 cm, ápice agudo ou acuminado, base cordada, subcordada ou subcuneada, margens inteiras ou espaçadamente denticuladas. Brácteas ovaladas a oblongas, 2-3,5$(-4,5) \times 1,5-2(-3,2) \mathrm{cm}$. Pedúnculos solitários, 3-6 cm; pedicelo $0,4-0,6 \mathrm{~cm}$. Flores $8,5-10 \mathrm{~cm}$ diâm.; tubo do cálice campanulado, 1-1,8 × 1,2-1,5 $\mathrm{cm}$; sépalas oblongas, 3,3-4 × 1-1,5 cm; pétalas 

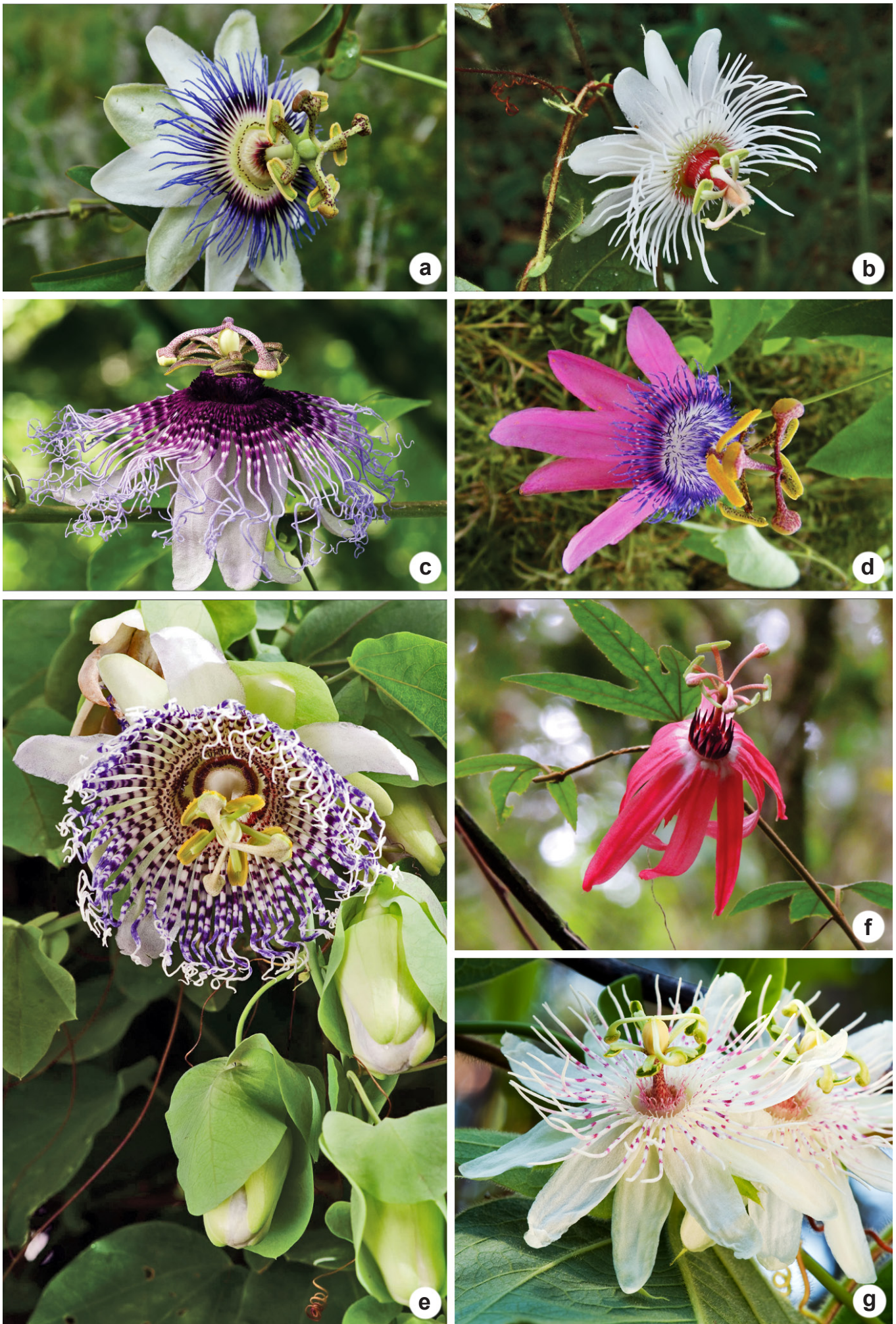

Figura 3 - Passiflora subgênero Passiflora - a. Passiflora caerulea. b. P. campanulata. c. P. cincinata. d. P. edmundoi. e. P. tetraden. f. P. speciosa. g. P.P. villosa.

Figure 3 - Passiflora subgenus Passiflora - a. Passiflora caerulea. b. P. campanulata. c. P. cincinata. d. P. edmundoi. e. P. tetraden. f. P. speciosa. g. P.P. villosa. 
oblongas, 3,5-4,2 × 1-1,8 cm, purpúreas; corona de filamentos em 4(-5) séries desiguais; 2 séries externas filamentos cilíndricos levemente atenuados nos ápices, 3-4,2 cm, 1(-2) séries subsequentes filamentos tuberculados, $0,3-0,4 \mathrm{~cm}$, série interna com filamentos capilares, $0,2-0,3 \mathrm{~cm}$; androginóforo 1,5-2,5 cm, 2 trócleas na porção mediana; ovário oblongo a obovado, glabros. Frutos bagas ovaladas ou piriformes, 8-11 $\times 4-6 \mathrm{~cm}$; sementes cordadas, oblongas, $0,7-0,8 \times 0,5-0,6 \mathrm{~cm}$, testa reticulada.

Material examinado: Belo Horizonte, 11.VII.1995, J.A. Lombardi \& L.G. Temponi 903 (BHCB). Brumadinho, 26.III.2010, G.M. Miranda 73 (BHCB). Caeté, Serra da Piedade, 27.IV.1986, TSMG et al. 2235 (BHCB). Caldas, Pocinhos de Rio Verde, 28.III.2008, M.G. Rezende et al. 93 (CESJ). Carangola, 14.V.1991, L.S. Leoni 1567 (UPCB). Caratinga, 26.V.1984, P.M. Andrade \& M.A. Lopes 246 (UPCB). Conceição de Ibitipoca, Parque Estadual de Ibitipoca, 3.I.2013, D.C. Imig 116 (UPCB). Conceição do Rio Verde, 4.I.2013, D.C. Imig 120 (UPCB). Coronel Pacheco, 10.X.1940, E.P. Heringer 427 (VIC). Delfim Moreira, 19.III.2011, A.L. Gasper 2694 (BHCB); Estação Biologica Entre Rios de Minas, 17.IV.1970, L. Krieger 8423 (UPCB). Juiz de Fora, 17.III.2005, N.M. Farinazzo \& F.M. Ferreira 01 (CESJ); 18.II.2008, A.C. Mezzonato \& Menini Neto 02 (CESJ). Matias Barbosa, 21.IX.2007, L.B.V. Matta \& L. Menini Neto 55 (CESJ). Nova Lima, Morro do Chapéu, 6.VI.1982, T.S.M.G. \& P.M. Andrade 1013 (BHCB). Novo Cruzeiro, 2.X.2004, J.R. Stehmann et al. 3544 (BHCB); Medina-Itaobim, 9.I.1968, A.P. Duarte 10632 (RFA). Ouro Preto, Lavras Novas, 19.V.1991, J.R. Stehmann 1272 (BHCB). Poços de Caldas, 19.I.1980, A. Krapovickas et al. 35362 (MBM). Teixeira, 22.V.1978, J. Fontella Pereira 1031 (VIC). Viçosa, IV.1930, Y. Mexia 4789 (VIC, L, G).

Passiflora alata é endêmica do Brasil, ocorrendo no Acre, Amazonas, Pará, Alagoas, Bahia, Ceará, Paraíba, Pernambuco, Sergipe e nas regiões Centro-Oeste, Sudeste e Sul, em domínio de Mata Atlântica, Cerrado e Amazônia. Difere-se das demais espécies ocorrentes em Minas Gerais por ter um caule quadrangular e alado. As ilustrações da espécie podem ser encontradas em Masters (1872, fig. 114), Sacco (1980, p. 47, fig. 10), Cervi (1996, p. 27, fig. 2), Deginani (2001, p. 56, fig. 6), Nunes \& Queiroz (2006, p. 203, fig. 3a-c), Farinazzo \& Salimena (2007, p. 826, fig. 1a-d), Imig \& Cervi (2013), MezzonatoPires et al. (2013, p. 126, fig. 1a), Costa et al. (2015, p. 276, fig. 2a-b), Vitta \& Pirani (2015, p. 31, fig. 1a) e Moraes (2016, pág. 53, fig. 15a-e).

20. Passiflora amethystina Mikan, Del. Fl. e Faun. Bras. Fasc. 4: Tab. 20. 1825.

Trepadeiras herbáceas, glabras. Caules cilíndricos. Estípulas oblongas, reniformes, 1,8-4 $\times 1-1,8 \mathrm{~cm}$. Folhas com pecíolos 2-8(-16-18) cm, 4-6(-8) glândulas longo-estipitadas, 0,1-0,2 cm; lâminas foliares simples, 3-lobadas, 4-11$(-17) \times(5-) 7-11(-18) \mathrm{cm}$, lobos ovalados ou oval-elípticos, ápice agudo-mucronados, base cordada a subcordada, margem inteira a glandular-serreada nos sinus e próximo à base. Brácteas ovaladas, oval-lanceoladas a elípticas, $0,8-2 \times 0,5-1,4 \mathrm{~cm}$, margem inteira ou glandularserreada. Pedúnculos solitários 2,4-11(-16) cm; pedicelos 0,7-1 cm. Flores 3,5-9 cm diâm.; tubo do cálice curto-campanulado, 0,4-0,6 × 0,7-1,3 $\mathrm{cm}$; sépalas oblongas, $2,3-3,2(-4) \times 0,7-1,3(-1,5)$ $\mathrm{cm}$, aristadas dorsalmente; pétalas oblongas a oblongo-lanceoladas, 1,8-3 × 0,5-1,2 cm, violáceas; corona de filamentos $4-5$ séries, as 2 séries externas filamentos filiformes $1-2,8 \mathrm{~cm}$, 2-3 últimas séries filamentos filiformes com ápice capitado, 0,4-0,8 cm; androginóforo 1,5-2,3 cm; ovário elipsoide ou ovalado, densamente piloso. Frutos bagas elípticas 5-8 × 2-3,5 cm; sementes ovaladas, $0,4-0,5 \times 0,2-0,3 \mathrm{~cm}$, testa foveolada. Material examinado: 1845, Wildgren $574(\mathrm{~S})$. Aiuruoca, 31.XII.2012, D.C. Imig 93 (UPCB); Parque Estadual do Papagaio, 12.III.2008, P.L. Viana et al. 3911 (UPCB). Araponga, Serra do Brigadeiro, 16.VI.1993, M.P.F. Vieira 799 (UPCB, VIC). Barroso, 9.III.1930, Y. Mexia 4448 (BM). Belo Horizonte, 6.II.1933, M. Barreto 863 (BHCB). Bom Jesus da Cachoeira, 12.V.1983, G. Hatschbach 46295 (MBM). Brumadinho, Retiro das Pedras, 18.II.2003, J.R. Stehmann 3283 (BHCB); 21.III.2002, A. Fonseca 204 (BHCB). Caeté, 30.X.1933, M. Barreto 865 (BHCB). Caldas, 15.V.1870, Regnell I 164 (S, LE). Caratinga, 26.V.1984, P.M. Andrade et al. 246 (BHCB). Delfim Moreira, 17.III.2011, T.E. Almeida et al. 2894 (BHCB). Itabirito, 15.I.2008, L.J. Arruda et al. 281 (BHCB); 8.IV.1999, J.A. Lombardi 2708 (BHCB). Itamonte, Fazenda Campo Redondo, 8.III.2001, F.B. Pereira 05-78 (RFA). Juiz de Fora, Morro de Imperador, D.S. Pifano \& R.M. Castro 351 (CESJ); 18.VII.2008, A.C. Mezzonato \& L. Menini 01 (CEJS). Lima Duarte, P.M. Andrade et al. 1142 (UPCB, BHCB); 3.I.2013, D.C. Imig 118 (UPCB, MBM). Marliéria, 15.VI.1995, J.A. Lombardi et al. 785 (BHCB); 10.VII.1999, L.G. Temponi et al. 46 (VIC, UPCB); 17.V.1999, R.C. Botoluzzi et al. 629 (VIC); Morro do Chapéu, 28.IV.1982, TSHG et al. 993 (BHCB). Muriaé, 13.VI.1991, G. Hatschbach 55420 (MBM); Parque Estadual de Ibitipoca, P.M. Andrade et al. 1142 (BHCB). Pedralva, Serra da Pedra Branca, 5.VI.2004, P. Braga 222 (CESJ); Reserva Biológica da Represa do Grama, 27.V.2001, R.M. Castro et al. 411 (CESJ). Santa Maria do Salto, 22.VIII.2003, J.A. Lombardi et al. 5356 et 5540 (BHCB). Teixeiras, 11.IV.2002, G.E. Valente 453 (UPCB, VIC). Viçosa, 2.III.1930, Y. Mexia 4448 (VIC, G). 
Passiflora amethystina não é endêmica do Brasil. No Brasil, ocorre na Bahia, e nas regiões Centro-Oeste, Sudeste e Sul, em domínio de Mata Atlântica, Cerrado e Caatinga (BFG 2015; Flora do Brasil 2020). Está fortemente relacionada com $P$. loefgrenii que vegetativamente são muito semelhantes. Passiflora loefgrenii possui os filamentos externos e internos da corona congestos ao redor do androginóforo de tamanhos semelhantes entre si, os filamentos externos não ultrapassam a metade das pétalas, o perianto é roxo ou violeta com filamentos violeta, ovário glabro e glauco e enquanto que $P$. amethystina é a série de filamentos externos tem tamanho semelhante às pétalas, radiadas, e as séries internas são menores e capitados, o perianto púrpura com filamentos violeta, além disso esta espécie apresenta processos dentiformes no interior do opérculo e ovário piloso. Passiflora junqueirae Imig \& Cervi que apesar de não haver até o momento registro para Minas Gerais, é uma espécie relacionada às anteriores, mas diferese de ambas por ser escassamente pilosa, com lóbulos das folhas oblongos lanceolados, não apresenta glândulas no sinus, as brácteas lineares e alternadas e as sépalas apresentam aristas dorsais $2-3,5 \mathrm{~cm}$. As ilustrações de $P$. amethystina podem ser encontradas em Masters (1872, fig. 123), Sacco (1980, p. 83, fig. 20), Cervi (1996, p. 31, fig. 6), Cervi (1997, p. 69, fig. 8), Deginani (2001, p. 59, fig. 8), Milward-de-Azevedo \& Valente (2004, p. 370, fig. 1a-e), Nunes \& Queiroz (2006, p. 203, fig. 3d-f), Farinazzo \& Salimena (2007, p. 826, fig. 1e-h), Milward-de-Azevedo (2007a, p. 75, fig. 1a-g), Mezzonato-Pires et al. (2013, p. 126, fig. 1b) e Moraes (2016, pág. 53, fig. 15f-j). Foi avaliada pelo CNCFlora (2016) como LC (menos preocupante), de acordo com os critérios da IUCN.

\section{Passiflora boticarioana Cervi, Britonia 58(4):} 385-387. 2006.

Trepadeiras herbáceas, pubérulas. Caules cilíndricos. Estípulas assimétricas pinatissectas, $0,3-0,6 \times 0,4-0,6 \mathrm{~cm}$. Folhas com pecíolos $1-1,5$ cm compr., 2-4 glândulas estipitadas; lâminas foliares simples, oval-lanceoladas, 7-13 × 2-3,3 $\mathrm{cm}$, ápice agudo-mucronado, base arredondada a subpeltada, margem inteiras a espaçadamente glandular denteada. Brácteas ovaladas a ovallanceoladas, pinatissectas, $1,5-2 \times 0,6-0,8 \mathrm{~cm}$, margem glandular-ciliadas. Pedúnculos aos pares, $1-1,5 \mathrm{~cm}$ compr.; pedicelo de $0,3-0,5 \mathrm{~cm}$ compr. Flores 3,8-4,2 cm diâm.; tubo do cálice curto- campanulado a pateliforme, $0,2-0,3 \times 0,6-0,7 \mathrm{~cm}$; sépalas oblongo-lanceoladas, $1,5-1,7 \times 0,6-0,8$ $\mathrm{cm}$, aristada; pétalas oblongo-lanceoladas, 1,5$1,6 \times 0,6-0,7 \mathrm{~cm}$; corona de filamentos 2 séries, filiformes, 1,3-1,7 cm compr.; androginóforo 1-1,2 cm compr.; ovário elipsóide, glabro. Frutos bagas elipsóides, $2-2,3 \times 1,7-1,9 \mathrm{~cm}$; sementes não vistas.

Material examinado: Bandeira, 1.III.2004, J.A. Lombardi et al. 5741 (BHCB Holotypus!, UPCB Isotypus!). Conceição do Mato Dentro, II.2012, L.B. Carvalho (BHCB 006888).

Passiflora boticarioana é endêmica do Brasil, ocorrendo somente em Minas Gerais (BFG 2015). Está relacionada com $P$. hypoglauca e $P$. foetida var. foetida, porém, $P$. hypoglauca possui estípulas semi-ovaladas, inteiras e denteadas na margem, brácteas lanceoladas e margens denteadas, ovário piloso e tricomas não viscosos e P. foetida var. foetida possui folhas trilobadas, cobertas por tricomas viscosos nos caules, folhas e estípulas, enquanto $P$. boticarioana possui estípulas pinatissectas, brácteas ovaladas a oval-lanceoladas, pinatissectas, ovário glabro e tricomas não viscosos (Cervi 2006).

\section{Passiflora caerulea L., Sp. Pl. 959, 1753.}

Fig. 3a

Trepadeiras herbáceas a subherbácea, completamente glabras. Caules cilíndricos. Estípulas reniformes ou subreniformes, 1,5-2 $\times 0,5-1,2 \mathrm{~cm}$. Folhas com pecíolos 2,5-6 cm compr., 2-4(-6) glândulas estipitadas; lâminas foliares simples, palmatilobadas, geralmente pentalobadas, raramente três, sete ou nove lobos, $5-7,2 \times 7-9 \mathrm{~cm}$, lobos oblongo-lanceolados ou oblongos, margens inteiras ou serrilhados, 2 pares de glândulas curto-estipitadas nos sinus dos lobos. Brácteas ovaladas ou oval-lanceoladas, 1,5-3 $\times 1,5-2,5 \mathrm{~cm}$. Pedúnculos solitários, 2,5-5 $\mathrm{cm}$ compr.; pedicelo $0,2-0,4 \mathrm{~cm}$ compr. Flores 7-10 cm diâm.; tubo do cálice campanulado, $0,8-1 \times 0,6-1 \mathrm{~cm}$; sépalas oblongas a oblongolanceoladas, 1,5-2,5 × 1-1,5 cm, aristada; pétalas oblongas a oblongo-lanceoladas, 1,5-2,5 × 1-1,3 $\mathrm{cm}$; corona de filamentos 3-4 séries, duas séries externas filiformes, $0,8-2,5 \mathrm{~cm}$ compr., $1(-2)$ séries seguintes capitados no ápice, $0,2-0,4 \mathrm{~cm}$ compr.; androginóforo $1-1,8(-3,3) \mathrm{cm}$ compr.; ovário ovalado a subgloboso, glabro. Frutos bagas, ovalado a subgloboso, 3-4,5 × 3-3,5 cm; sementes obcordadas a ovaladas, $0,3-0,4 \times 0,2-0,3 \mathrm{~cm}$, testas alveoladas. 
Material examinado: Descoberto, 14.X.2001, R.C. Forzza et al. 1892 (MBM, CESJ). Caldas, Regnell III 636 (K, Typus de P. caerulea ver. Regnellii Mast., S). Delfim Moreira, 21.III.2011, L.L. Giacamin 1561 (BHCB). Juiz de Fora, 25.X.1973, L.K. Krieger 13133 (MBM; UFJF).

Espécie distribuida por todos os estados do Nordeste, Sudeste e Sul,Sudeste e Sul nos domínios fotogeográficos de Caatinga e Mata Atlântica (BFG 2015; Flora do Brasil 2020). Passiflora caerulea, quando vegetativa, pode ser confundida com $P$. filamentosa, porém esta ultima apresenta estipulas lineares, enquanto em $P$. caerulea as estipulas são reniformes. As flores de $P$. caerulea são alvas com filamentos azuis escuros enquanto em $P$. filamentosa os filamentos possuem a base púrpura, uma banda branca e lilases nos ápices. As ilustrações da espécie podem ser encontradas em Sacco (1980, p. 78, fig. 19), Cervi (1997, p. 65, fig. 7) e Deginani (2001, p. 62, fig. 10).

23. Passiflora campanulata Mast., Fl. bras. 13(1): 615. 1872.

Fig. $3 b$

Trepadeiras herbáceas, densamente pilosas. Caules cilíndricos. Estípulas reniformes, 0,8-1,2 $\times$ 0,3-0,6 cm, margens glandular serreada, glândulas estipitadas. Folhas com pecíolos 1,5-2,2 cm compr., 4-6 glândulas longo estipitadas; lâminas foliares simples, trilobadas, 3,5-6 × 5-6,5 cm, lobos oblongos, ápice agudo ou arredondado, acuminado, base cordada ou subcordada, margens inteiras e glandular denteadas na base. Brácteas ovaladas a oval-lanceoladas, 1,5-2,3 × 0,7-1,2 cm, margens glandular serreada. Pedúnculos solitários, raramente aos pares, 1,5-2,5 cm compr.; pedicelo 0,1-0,3 cm compr. Flores 3,5-5,2 cm diâm.; tubo do cálice curto-campanulado a pateliforme, 0,5-0,9 $\times$ 0,4-0,6 cm; sépalas oblongo-lanceoladas, 1,5-2,2 $\times$ 0,4-0,6 cm, aristadas; pétalas oblongo-lanceoladas, 1,3-2 $\times 0,4-0,5 \mathrm{~cm}$; corona de filamentos 3 séries, série externa filiformes, 1-1,8 cm compr., duas séries internas filiformes à capilares, com ápice capitado, 0,2-0,3 cm compr.; androginóforo 0,8-1 cm compr.; ovário ovalado à oblongo, densamente piloso. Frutos bagas, elípticas a subglobosas, 1,5-3 $\times 1-2,5 \mathrm{~cm}$; sementes não vistas.

Material examinado: Aiuruoca, 1.I.2013, D.C. Imig 90 (UPCB, MBM). Conceição de Ibitipoca, Parque Estadual de Ibitipoca, 3.I.2013, D.C. Imig 114 (UPCB, MBM). Lima Duarte, Parque Estadual de Ibitipoca, 23.III.2002, A.S.M. Valente \& F.S. Araújo 166 (CESJ, UEC, UPCB); 17.III.2005, R. Marquete \& S. Von Medeiros 3587 (RB, MBM); 9.III.2004, R.C. Forzza et al. 3026 (MBM, RB, K). Oliveira, 19.I.1999, F.C. Campos Neto (UPCB 42949). Rio Preto, 27.I.2007, L. Menini Neto et al. 304
(UPCB 58351, CESJ 48531). Santa Rita do Sapucaí, 20.II.1996, O.S. Ribas 1322 (MBM).

Espécie endêmica do Brasil, ocorre nos estados de Minas Gerais, Rio de Janeiro, São Paulo, Paraná e Santa Catarina (BFG 2015; Flora do Brasil 2020). Passiflora campanulata pode ser confundida com $P$. villosa e $P$. vellozii, especialmente pela semelhança das flores. Vegetativamente, $P$. campanulata apresenta as estípulas reniformes de margens glândulas denteadas, enquanto as demais apresentam estípulas oval a oval-lanceoladas, porém em $P$. villosa as margens são glandulares bipinatissectas e em $P$. vellozii as margens glandulares denteadas. As ilustrações da espécie podem ser encontradas em Sacco (1980, p. 111, fig. 27), Cervi (2000, p. 104, fig. 5), Bernacci et al. (2003, p. 263, fig. 1a-c), Milward-de-Azevedo (2007a, p. 75, fig. 1h-n) e Mezzonato-Pires et al. (2013, p. 126, fig. 1c-d). Foi avaliada pelo CNCFlora (2016) como LC (menos preocupante), de acordo com os critérios da IUCN.

24. Passiflora cincinnata Mast., Gard. Chron. 966. 1868.

Fig. 3c

Trepadeiras lenhosas, glabras ou velutinas. Caules cilíndricos. Estípulas lineares, 0,8-1 $\times$ ca. $0,1 \mathrm{~cm}$. Folhas com pecíolos 2-6 cm compr., 2 glândulas orbiculares, sésseis $0,1-0,2$ cm compr.; lâminas foliares simples, (3-)5 palmatipartidas, 5-9 × 8-12 cm, lobos oblongos a oblongo-lanceolados, ápice agudo ou arredondado, mucronado, base longamente atenuada, margens glandular-serrilhadas. Brácteas ovaladas ou oblongas, 2-4 × 1,5-2,5 cm, margem inteira com 1-3 glândulas orbiculares próximo à base. Pedúnculos solitários 3-8 cm compr.; pedicelos 0,5-1,5 cm compr. Flores $7-11 \mathrm{~cm}$ diâm.; tubo do cálice campanulado, 1-1,5 × 1-2 cm; sépalas oblongas, 3-4 × 1-1,5 cm, aristadas; pétalas oblongas a oblongo-lanceoladas, 2,5-3,5 × 1-1,5 cm; corona de filamentos 13-15(-17) séries desiguais; duas séries externas cilíndricas, ápice atenuado e cincinado, 2,8-4,3 cm compr., 1-2(-3) séries seguintes filiformes, capitados, 0,5-1 cm compr., 7-8(-11) séries seguintes filiformes, capitados, 0,2-0,4 cm compr., série interna situada à $0,1 \mathrm{~cm}$ compr. das séries anteriores, justaposta aos filamentos do opérculo, filiformes $0,5-0,8 \mathrm{~cm}$ compr.; androginóforo 1,5-2 cm compr., tróclea ca. $0,5 \mathrm{~cm}$ compr. da base; ovário ovalado a elíptico, glabro. Frutos bagas, globosas ou subglobosas, 5-7 cm diâm.; sementes oblongas ou obovadas, $0,4-0,6$ $\times 0,2-0,4 \mathrm{~cm}$, testa reticulada. 
Material examinado: M. Claussen 382 (S); 16.I.1965, G.F.J. Pabst 8357 (NY 1550529) (M). Almenara, 4.XII.2003, O.P. Rezende 01 (VIC). Bandeira, 6.X.2003, A. Salino et al. 9114 (BHCB, UPCB). Belo Horizonte, 19.I.1996, J.A. Lombardi 1050 (BHCB, UPCB). Claro dos Poções, 13.III.1995, G. Hatschbach et al. 61837 (MBM). Cristália, 10.II.1991, G. Hatschbach et al. 55025 (MBM). Francisco Sá, 6.VI.2010, A.C. Cervi 9666 (MBM). Itaobim, 18.I.1984, G. Hatschbach 47342 (MBM); 13.I.1968, A.P. Duarte 10621 (RFA). Jaíba, 18.V.1978, M.P. Coons 78-605 (VIC). Januária, 23.V.1997, J.A. Lombardi et al. 1693 (BHCB); 21.VII.1997, A. Salino \& J.R. Stehmann 3333 (UPCB, BHCB). Juiz de Fora, 18.II.1947, L. Krieger 14688 (BHCB, MBM). Matias Cardoso, 18.IV.2007, J.M. Silva et al. 5773 (MBM). Medina, 26.V.1999, A. Salino et al. 4677 (BHCB, UPCB). Montes Claros, 9.II.1991, G. Hatschbach et al. 54936 (MBM). Novo Cruzeiro, 2.X.2004, J.R. Stehmann et al. 3530 (BHCB). Pedra Azul, 28.V.1999, A. Salino et al. 4708 (BHCB, UPCB); 20.IV.1964, Z.A. Trinta 815 \& E. From 1891 (RFA). Prata, 2.IV.1976, G. Hatschbach et al. 38571 (MBM). Salto da Divisa, 19.II.2003, J.A. Lombardi et al. 5071 (BHCB, MBM, UPCB). Teófilo Otoni, 8.I.2011, L.F.A. Paula et al. 188 (BHCB). Unaí, 20.I.2002, A. Salino et al. 7888 (BHCB, UPCB).

Espécies distribuídas nos estados do Pará, Tocantins, em todos os estados do Nordeste e do Centro-Oeste, em Minas Gerais e São Paulo, nos domínios fitogeográficos de Amazônia, Caatinga, Cerrado e Mata Atlântica (BFG 2015; Flora do Brasil 2020). Passiflora cincinnata é facilmente distinta das demais espécies ocorrentes em Minas Gerais, mas pode ser vegetativamente confundida com $P$. filamentosa por ambas apresentarem folhas palmatilobadas e duas glândulas no pecíolo, porem os filamentos da corona em $P$. cincinnata são cincinados nos ápices, enquanto $P$. filamentosa não apresenta esta característica. As ilustrações da espécie podem ser encontradas em Sacco (1980, p. 64, fig. 15), Deginani (2001, p. 74, fig. 16), Vitta (2006, p. 10, fig. 1g), Costa et al. (2015, p. 276, fig. 2c-d) e Vitta \& Pirani (2015, p. 31, fig. 1b-c).

25. Passiflora clathrata Mast., Fl. bras. 13 pl.(1): 580. 1872.

Subarbustos herbáceos, $10-60 \mathrm{~cm}$, densamente pilosas. Caules cilíndricos. Estípulas semicirculares profundamente pinatisectas, $0,3-0,7 \times 0,2-0,6 \mathrm{~cm}$, ápices das lacínias glandularcapitados. Folhas com pecíolos $0,5-1,5 \mathrm{~cm}$ compr., cobertos por tricomas glandulares; lâminas foliares simples, inteiras à superficialmente 3-lobadas, oblongas ou ovaladas, $3-7 \times 2-5 \mathrm{~cm}$, ápice agudo ou arredondado, base cordada ou subcordada, margens glandular denticuladas. Brácteas ovaladas, bipinatissectas, $1-1,8 \times 0,5-1,4 \mathrm{~cm}$, ápices das pinas glandular-capitados. Pedúnculos solitários, 1,5-2,6 cm compr.; pedicelo $0,2-0,4 \mathrm{~cm}$ compr. Flores 3-4 cm diâm.; tubo do cálice curtocampanulado a pateliforme, $0,5-0,9 \times 0,5-0,7 \mathrm{~cm}$; sépalas oblongo-lanceoladas, $1,5-1,8 \times 0,4-0,6$ $\mathrm{cm}$, aristadas; pétalas oblongo-lanceoladas, $1-1,5$ $\times 2-3,5 \mathrm{~cm}$; corona de filamentos $4(-6)$ séries, duas séries externas filiformes, $0,7-1,3 \mathrm{~cm}$ compr., 2(-4) séries internas capilares, $0,2-0,3 \mathrm{~cm}$ compr.; androginóforo $0,8-1,2 \mathrm{~cm}$ compr.; ovário ovalado à subgloboso, densamente velutino. Frutos bagas, globosas a subglobosas, raramente ovaladas, 1,4-3 $\times 1-2,5 \mathrm{~cm}$; sementes oblongas a elípticas, $0,3-0,5$ $\times 0,2-0,3 \mathrm{~cm}$, testa foveolada.

Material examinado: A. Saint Hilaire 465 (P); 1845, Wildgren 578 (S). Caldas, 11.V.1873, Mosen 528 (S). Congonhas, Catl B2 2157 (P). Corinto, 20.X.1999, A.C. Cervi et al. 6901 (MBM). Felixlândia, 11.IV.2004, E. Tameirão Neto 3748 (BHCB). Gouveia, 15.XI.2010, J. Cordeiro et al. 3925 (MBM). Joaquim Felício, 20.X.1999, A.C. Cervi et al. 6905 (MBM). Moeda, 21.X.2001, R.C. Mota 1428 (BHCB). Nova Lima, Morro do Chapéu, 27.XII.1980, TSMG 534 (BHCB). Uberaba, 13.VI.1990, G. Hatschbach \& J.M. Silva 54480 (MBM).

Espécie apresenta distribuição nos estados de Goiás, Minas Gerais, Mato Grosso, Distrito Federal, Bahia e São Paulo. Passiflora clathrata é facilmente distinta das demais espécies ocorrentes em Minas Gerais por ser a única espécie subarbustiva. Espécie xilipodífera, podendo portanto, desaparecer em períodos de seca e rebrotando ao final do mesmo. As ilustrações da espécie podem ser encontradam em Imig \& Cervi (2013. fig. 02: E-J), Masters (1872, fig. 110 I), Cervi (1986, p. 22, fig. 2) e Vitta \& Pirani (2015, p. 31, fig. 1d-e).

26. Passiflora edmundoi Sacco, Sellowia 18: 44 fig. 3,4,5. 1966.

Fig. $3 \mathrm{~d}$

Trepadeiras herbáceas, completamente glabras. Caules cilíndricos. Estípulas reniformes, $1,5-3 \times 0,7-1,5 \mathrm{~cm}$, margens glandular denteadas a sub-inteiras. Folhas com pecíolos 3,5-5 cm compr., 3-7 glândulas longo estipitadas; lâminas foliares simples, trilobadas, 3,5-6,5(-10) × 5-7(-12) cm, lobos oblongos a oblongo-lanceolados, ápice obtuso a arredondado-acuminado, base cordada a subpeltada, margens inteiras ou espaçadamente glandular-denteadas próximo ao sinus dos lobos. Brácteas ovaladas a oval-lanceoladas, $0,4-0,8$ $\times 0,2-0,5 \mathrm{~cm}$, margens glandular serreadas. Pedúnculos solitários, 7-15 cm compr.; pedicelo 0,4-0,5 cm compr. Flores 5-7 cm diâm.; tubo 
do cálice curto-campanulado, 1-1,5 × 0,6-1 cm; sépalas oblongo-lanceoladas, $3-3,8 \times 0,5-0,8$ $\mathrm{cm}$, aristada; pétalas oblongo-lanceoladas, 3-4 $\times$ 0,5-0,9 cm; corona de filamentos 2 séries, série externa subulados, 1-2,5 cm compr., série interna membranácea, ápice dilacerado, 2-3 cm compr.; androginóforo 2,2-3,5 cm compr.; ovário fusiforme, glabro. Frutos bagas, fusiformes, angulados, 5-6,5 × 1-1,5 cm; sementes não vistas. Material examinado: Cel. Eneas, 19.V.1983, G. Hatschbach 46580 (MBM). Cristália, 10.II.1991, G. Hatschbach et al. 54998 (MBM); 28.XI.1991, M.G.C. et S.T.S 780 (BHCB). Francisco Sá, 20.III.1980, G. Hatschbach 42836 (MBM). Januária, 15.II.1998, J.A. Lombardi et L.G. Temponi 2158 (BHCB). Juramento, 4.XII.2004, G. Hatschbach \& E. Barbosa 78817 (MBM) Manga, 28.II.1991, M.B. Horta et al. 475 (BHCB,UPCB). Marliéria, 20.I.1998, M.G. Bovini 1280 (UPBC, VIC). Monte Azul, 14.I.1997, G. Hatschbach et al. 65708 (MBM). Serranópolis de Minas, 26.IV.2013, E. Barboza et al. 3798 (MBM). Tanque Novo, 17.VI.2004, G. Hatschbach et al. 77971 (MBM). Novo Cruzeiro, 2.X.2004, J.R. Stehmann et al. 3529 (BHCB, UPCB). Turmalina, 4.XII.1991, M.G.C. \& S.T.S. 866 (BHCB, UPCB); 7.I.1998, A.F. Carvalho 478 (UPCB, VIC).

Espécie endêmica do Brasil, distribuída pelos estados da Bahia, Espírito Santo e Minas Gerais nos domínios fitogeográficos de Caatinga e Mata Atlântica (BFG 2015; Flora do Brasil 2020). Passiflora edmundoi é muito semelhante à $P$. kermesina, especialmente vegetativamente. Porém, as flores de $P$. edmundoi possuem um anel membranáceo interno a corona de filamentos, essa membrana excede o tubo do cálice, ficando visivelmente exposta, ainda, as brácteas de $P$. edmundoi são alternas, dispersas a partir da porção mediana do pedúnculo, de coloração rósea e são persistentes, enquanto em $P$. kermesina, as brácteas são lineares e verticiladas, porém situadas a ca. de $1 \mathrm{~cm}$ do tudo do cálice e cedo decíduas. A ilustração da espécie pode ser encontrada em Nunes \& Queiroz (2006, p. 205, fig. 7c-d).

27. Passiflora edulis Sims, Bot. Mag. 45, tab. 1989. 1818.

Trepadeiras lenhosas, glabras ou pubérulas. Caules cilíndricos. Estípulas linear-subuladas, $0,7-1,5 \times 0,2-0,4 \mathrm{~cm}$. Folhas com pecíolos $1-3,5$ cm compr., 2 glândulas côncavas, sésseis, $0,1 \mathrm{~cm}$ compr.; lâminas foliares simples, 3-lobadas, raramente elípticas ou ovaladas, 6-11 × $7-12 \mathrm{~cm}$, lobos oval-elípticos, ápice agudo a arredondados, mucronados, base cordada a subcordada, margens glandular-serrilhadas. Brácteas ovaladas a oblongas,
1,5-3 × 1-2,5 cm, margens serreadas à glandularserreadas próximo à base. Pedúnculos solitários, 2-4,5 cm compr.; pedicelo 0,7-1,5 cm compr. Flores 5-9 cm diâm.; tubo do cálice campanulado, 0,5-1,4 × 1-1,5 cm; sépalas oblongas, 2-3,5 $\times$ 0,8-1,5 cm, aristadas, 1-2 glândulas orbiculares no ápice; pétalas oblongas, 2,2-3,6 × 0,7-1,5 cm; corona de filamentos $5(-7)$ séries, duas séries externas filiformes, ápice levemente atenuado e cincinado, 1-2,5 cm compr., 3(-5) séries seguintes dentiformes, 0,1-0,4 cm compr.; androginóforo 1,5-2 cm compr., tróclea na altura do opérculo; ovário oblongo a subgloboso, tomentoso. Frutos bagas, globosas a subglobosas, raramente ovaladas, 3-8(-11) × 3-9 cm; sementes oblongas a elípticas, $0,3-0,5 \times 0,2-0,3 \mathrm{~cm}$, testa reticulada a faveolada. Material examinado: Lindberg 361 (BR, S); Regnell II 128 (S); Warming 1113 (C); Saint Hilaire 680 (P). Aiuruoca, 31.XII.2012, D.C. Imig 102 (UPCB). Bento Rodrigues, IX.1945, Gardner 4691 (BM). Brumadinho, Casa Branca, 17.II.2010, G.M. Miranda 70 (BHCB). Caldas, H. Mosen 340 (S). Carangola, 5.X.1995, L.S. Leoni 3109 (UPCB). Catas Altas, Serra do Caraça, 18.IV.2005, R.C. Mota et al. 2889 (ICB, UFMG, BHCB). Itabirito, 30.X.1981, TSMG 788 (UFMG). Juiz de Fora, Morro de Imperador, 8.IV.2003, D.S. Pifano et al. 518 (CESJ). Pouso Alegre, VII.1970, P. Occioni 4227 (RFA). Raul Soares, 24.XI.1992, A. Carvalho 252 (VIC). Teofilo Otoni, 27.XII.2010, L.F.A. Paula et al. 228 (BHCB). Santa Rita do Jacutinga, 14.XI.2000, A. Salino \& L.C.N. Melo 5901 (HUFU, UFMG, BHCB, UPCB). Viçosa, 27.XII.1929, Y. Mexia 4173 (VIC).

Esta espécie é encontrada em quase todos os estados brasileiros, exceto Acre, Amapá, Rondônia e Roraima, em bordas de florestas, áreas perturbadas ou intactas, locais antropizados, vegetação litorânea e cerrados (BFG 2015; Flora do Brasil 2020). Economicamente é a principal espécie cultivada e seus frutos são comestíveis e amplamente utilizados na culinária, no preparo de bebidas alcoólicas e sucos (Vanderplank 1996). Além disso, tem importância medicinal, na fabricação de calmantes e as sementes trituradas são usadas como vermífugas (Bernacci et al. 2003). Devido a isso, Passiflora edulis é cultivada e comercializada em grande escala, ou nos jardins como planta ornamental e frutífera. As ilustrações da espécie podem ser encontradas em Masters (1872, fig. 122 I), Standley \& Williams (1961, p. 127, fig. 15), Sacco (1980, p. 67, fig. 16), Cervi (1996, p. 30, fig. 5), Deginani (2001, p. 77, fig. 18), Nunes \& Queiroz (2006, p. 205, fig. 7e-g), Farinazzo \& Salimena (2007, p. 826, fig. 1i-1), Imig \& Cervi (2013, fig. 03), Mezzonato-Pires et al. 
(2013, p. 126, fig. 1g), Costa et al. (2015, p. 276, fig. 2e-f) e Moraes (2016, pág. 53, fig. 15o-s). Foi avaliada pelo CNCFlora (2016) como LC (menos preocupante), de acordo com os critérios da IUCN.

28. Passiflora eichleriana Mast., Fl. bras. 13(1): 616, tab 128, fig. 05, 1872.

Trepadeiras herbáceas a subherbáceas, glabras. Caules cilíndricos. Estípulas reniformes ou subreniformes, 1,5-2 × 0,5-1,3 cm. Folhas com pecíolos 1,5-6 cm compr., 6-8 glândulas; lâminas foliares simples, trilobadas, 4-11(-17) × 5-11 cm, lobos ovalados ou oval-elípticos, ápice agudo acuminando, base cordada a subpeltada, margens inteiras, 2-4 glândulas estipitadas nos sinus dos lobos. Brácteas ovaladas, $1-1,8 \times 1-1,5$ $\mathrm{cm}$, margens inteiras ou glandular denticuladas próximo à base. Pedúnculos solitários, 2,5-5,5 cm compr.; pedicelo 0,2-0,3 cm compr. Flores 6-7(-9) cm diâm.; tubo do cálice campanulado, $0,8-1,1 \times 0,6-1 \mathrm{~cm}$; sépalas oblongo-lanceoladas, $2-2,5 \times 1-1,3 \mathrm{~cm}$, aristada, aristas $0,5-1 \mathrm{~cm}$ compr.; pétalas oblongo-lanceoladas, $1,5-2,4 \times$ $0,9-1,2 \mathrm{~cm}$; corona de filamentos 6 séries, duas séries externas filiformes, $1,8-2 \mathrm{~cm}$ compr., séries seguintes, capitados $0,3-0,4 \mathrm{~cm}$ compr.; androginóforo 1-1,3 cm compr.; ovário ovalado, glabro. Frutos bagas, globosos a subgloboso 2,5$4,5 \times 2,3-4 \mathrm{~cm}$; sementes obcordadas a ovaladas, $0,4-0,5 \times 0,2-0,3 \mathrm{~cm}$, alveoladas.

Material examinado: Aiuruoca, caminho do Vale do Matutu, 29.XII.2012, D.C. Imig 91 (UPCB, MBM).

Espécie encontrada nos estados do Mato Grosso do Sul, Mato Grosso, Minas Gerais, São Paulo, Paraná, Rio Grande do Sul, Santa Catarina nos domínios fitogeográficos de Cerrado, Mata Atlântica (BFG 2015). Passiflora eichleriana é morfologimente semelhante a P. tenuifila e muito confundida nos herbários, sendo sua identificação possível somente em estado reprodutivo. Passiflora tenuifila apresenta nas flores quatro séries na corona de filamentos e as duas séries externas são lilases a arroxeadas, enquanto em $P$. eichleriana a corona de filamentos é composta por 6 séries e esses são alvos ou raramente apresentam uma pequena porção lilás na base das duas séries dos filamentos externos. As ilustrações da espécie podem ser encontradas em Masters (1872, fig. 128 V), Sacco (1980, p. 95, fig. 23) e Cervi (1997, p. 82, fig. 12). Foi avaliada pelo CNCFlora (2016) como LC (menos preocupante), de acordo com os critérios da IUCN.
29. Passiflora filamentosa Cav. Diss. 10: 461. pl. 294. 1790.

Trepadeiras lenhosas, glabras ou esparsamente vilosas. Caules cilíndricos. Estípulas lineares 3-4× 0,8-1,7 cm. Folhas com pecíolos 4-5,5 cm compr., um par de glândulas sésseis ou subsésseis; lâminas foliares pentalobadas, lâminas 4-8 × 6,2-12,5 cm, lobos oblongo-lanceolados, ápice agudo, base cordada, glândulas nos sinus dos lobos. Brácteas ovadas ou ovado-espatuladas, $1-2 \times 0,8-1,2 \mathrm{~cm}$. Pedúnculos solitários, 4,8-6,5 cm compr.; pedicelo 0,3-0,5 cm compr. Flores $8-10 \mathrm{~cm}$ diâm.; tubo do cálice campanulado, $1-1,5 \times 1-1,3 \mathrm{~cm}$; sépalas oblongas a oblongo-lanceoladas, 3-4,7 × 1-1,3 cm, aristadas; pétalas oblongas a oblongo-lanceoladas, 2,8-4,5 × 1-1,3 cm; corona de filamentos 7 séries, duas séries externas filiformes, $2-2,5 \mathrm{~cm}$ compr., 5 séries seguintes cilíndricos, $0,2-0,5 \mathrm{~cm}$ compr.; androginóforo 2-2,3 cm compr.; ovário ovóide, tomentoso. Frutos bagas, globosas, 4-5,3 $\times 4-5$ $\mathrm{cm}$; sementes obcordadas, $1-2 \times 0,7-1 \mathrm{~cm}$, testas alveoladas.

Material examinado: Araponga, 19.IV.1925, Killip 9548 (MO). Marliéria, 20.IX.1974, E.P. Heringer 13985 (HB). Material adicional: BRASIL. ESPIRITO SANTO: Aldeamento Índias: 10.VII.1942, E.A. Bueno et $L$. Emygdio 185 (R). Linhares, Reserva Biológica de Sooretama), 10.VIII.1965. Nova Venécia, Serra do Cristalino, 16.XI.1953, A.P. Duarte 3711 (RB). RIO DE JANEIRO: Itatiaia, Parque Nacional do Itatiaia, Trilha Rui Braga. Grupo Verde (HRCB 64998). Petrópolis, Correias, 29.X.1946, Brade et Aparício 18693 (RB). Santa Maria Madalena, 8.III.1935, S. Lima et Brade 14242 (RB).

Espécie endêmica do Brasil, ocorrendo nos estados do Espírito Santo, Minas Gerais, Rio de Janeiro, em Mata Atlântica (BFG 2015; Flora do Brasil 2020). Passiflora filamentosa é facilmente distinta das demais espécies ocorrentes em Minas Gerais, mas pode ser vegetativamente confundida com $P$. cincinnata por ambas apresentarem folhas palmatilobadas e duas glândulas no pecíolo. Porém, os filamentos da corona em $P$. cincinnata são cincinados nos ápices enquanto $P$. filamentosa não apresenta esta característica. A ilustração da espécie pode ser encontrada em Moraes (2016, pág. 64, fig. 21).

30. Passiflora foetida var. foetida L., Sp. Pl. ed. 2: 959.1753.

Trepadeiras herbáceas, hirsutas ou vilosas. Caules cilíndricos. Estípulas subreniformes, $0,5-1,7 \times 0,5-1 \mathrm{~cm}$, pinatissectas, ápice glandular. Folhas com pecíolos 1-3 cm compr., 5-6 glândulas 
filiformes; lâminas foliares simples, inteiras ou superficialmente trilobadas, 3-6,5(-11) $\times$ $2-5,7(-7,8) \mathrm{cm}$, ápice arredondado, base cordada, margens glandular-serrilhadas. Brácteas ovaladas, bipinatissectas, $1,5-3,5 \times 1-2 \mathrm{~cm}$, pinas glandularciliadas, persistentes no fruto. Pedúnculos solitários 2-3,5 cm compr.; pedicelo $0,1-0,25 \mathrm{~cm}$ compr. Flores 2,5-4 cm diâm.; tubo do cálice curtocampanulado, $0,4-0,5 \times 0,7-0,8 \mathrm{~cm}$; sépalas oblongo-lanceoladas, $1-1,5 \times 0,3-0,5 \mathrm{~cm}$, aristadas, aristas glandulares; pétalas oblongo-lanceoladas, $1-1,4 \times 0,5-0,7 \mathrm{~cm}$; corona de filamentos 5 séries, duas séries externas filiformes $0,6-1 \mathrm{~cm}$ compr., três séries internas capilares, $0,1-0,2 \mathrm{~cm}$ compr.; androginóforo $0,6-1 \mathrm{~cm}$ compr.; ovário ovalado, piloso. Frutos bagas, globosas a subglobosas, $1,5-2,5 \times 1,3-2,6 \mathrm{~cm}$; sementes obovadas, $0,3-0,4$ $\times 0,2-0,3 \mathrm{~cm}$, testas foveoladas.

Material examinado: Catugi, V.1983, G. Hatschbach 46300 (MBM). Governador Valadares, 26.VIII.1978, M.P. Coons 78-1002 (VIC). Jequitinhonha, 27.III.2008, T.E. Almeida et al. 1327 (BHCB). Marliéria, R.L.C. Bortoluzzi et al. 375 (VIC). Monte Azul, 25.IV.2013, J. Cordeiro et al. 2309 (MBM). Salto da Divisa, 5.III.2004, J.A. Lombardi et al. 5843 (BHCB).

Recentemente, as 11 variedades de Passiflora foetida registradas para o Brasil foram sinonimizadas em apenas três variedades: entre elas, $P$. foetida var. foetida com ampla distribuição pelos estados brasileiros. Em Minas Gerais, ocorre apenas a $P$. foetida var. foetida que é facilmente circunscrita quando comparada com as outras espécies do estado por apresentar tricomas glandular-capitados e viscosos que quando tocados liberam um odor característico, folhas trilobadas com lóbulo central bem pronunciado e pecíolos com 5-6 glândulas filiformes dispersas. Quanto ao tamanho e coloração das flores, especialmente dos filamentos, é muito variável, geralmente dependendo do tipo de solo e do habitat, podem variar de alvescentes, lilases, roxos e azulados. As ilustrações da espécie podem ser encontradae em Sacco (1980, p. 101, fig. 25), Cervi (1986, p. 32, fig. 5), Deginani (2001, p. 83, fig. 22), Nunes \& Queiroz (2006, p. 205, fig. 7h-k), Silva et al. (2013, fig. 4a-e) e Costa et al. (2015, p. 279, fig. 3e-g).

31. Passiflora gardneri Mast., Fl. bras. 13, pt. 1: 614. 1872.

Trepadeiras herbáceas a subherbáceas, pilosas. Caules cilíndricos. Estípulas semi-ovaladas, 0,6-1,8 $\times 0,4-0,7 \mathrm{~cm}$, aristadas. Folhas com pecíolos 2-3,5 cm compr., 2-6 glândulas sésseis, orbiculares; lâminas foliares simples, trilobadas, 2-3,5 × 1,3-3,3 $\mathrm{cm}$, lobos ovalados a oval-lanceolados, ápice obtuso, base cordada. Brácteas lanceoladas, 1,8-2,2 $\times 0,5-0,8 \mathrm{~cm}$. Pedúnculos solitários $2-7 \mathrm{~cm}$ compr.; pedicelo 0,2-0,3 cm compr. Flores 5-6,3 cm diâm.; tubo do cálice campanulado, $0,5-0,6 \times$ ca. $0,4 \mathrm{~cm}$; sépalas oblongo-lanceoladas, $1,8-2 \times 0,7-1 \mathrm{~cm}$; pétalas oblongo-lanceoladas a lanceoladas, 2-2,5 $\times 0,5-0,9 \mathrm{~cm}$; corona de filamentos 5 séries, duas series exteriores filiformes $2-2,3 \mathrm{~cm}$ compr., séries seguintes filiformes capitados no ápice, $0,2-0,5$ cm compr.; androginóforo 1,3-2,1 cm compr.; ovário elipsóide, glabro, glauco e pruinoso. Frutos e sementes não vistos.

Material examinado: Formoso, Alto da Serra Grande, 14.IX.1972, J.A. Rizzo 8318 (UPCB).

Espécie endêmica do Brasil, distribuída nos estados de Minas Gerais, Goiás, no Cerrado (BFG 2015; Flora do Brasil 2020). Passiflora gardneri pode ser confundida com $P$. amethystina, porém esta última apresenta-se glabra e ovário piloso, enquanto $P$. gardneri é totalmente pilosa, mas o ovário é glauco e pruinoso. A ilustração da espécie pode ser encontrada em Cervi (1986, p. 35, fig. 6).

32. Passiflora hatschbachii Cervi, Fontqueria 40: 45-47, 1994.

Trepadeiras herbáceas a subherbáceas, pilosas. Caules cilíndricos. Estípulas setáceas, $0,4-0,5 \times$ ca. $0,1 \mathrm{~cm}$. Folhas com pecíolos 1,5-3,5 cm compr., 2 glândulas orbiculares; lâminas foliares simples, trilobadas, raramente inteiras, 4,5-8 $\times$ 3,8-7 cm, lobos oblongos, ápice arredondado a subtruncado, mucronado, base arredondada, cordada e subpeltada, margens inteiras a glandulardenteadas. Brácteas ovaladas a oval-lanceoladas, $0,8-2,3 \times 0,5-1,2 \mathrm{~cm}$, margens glandular-denteadas. Pedúnculos solitários, 6,5-10(-18) cm compr.; pedicelos $0,8-1,3 \mathrm{~cm}$ compr. Flores $4,8-8,5 \mathrm{~cm}$ diâm.; tubo do cálice campanulado, $0,8-1,2 \times$ 1-1,2 cm; sépalas oblongo-lanceoladas, 2,3-3,8 $\times$ $0,7-1,3 \mathrm{~cm}$, aristadas; pétalas oblongo-lanceoladas, 2,1-3,6 × 0,7-1 cm; corona de filamentos 2 séries, uma série externa filiformes, $1-1,3 \mathrm{~cm}$ compr., série seguinte filiformes a capilares, $0,3-0,4 \mathrm{~cm}$ compr.; androginóforo 1,5-2,3 cm compr.; ovário elipsoide, densamente piloso. Frutos bagas, oblongas a ovaladas, 3,8-5,3 × 2,5-3,5 cm; sementes ovaladas, $0,4-0,6 \times 0,2-0,3 \mathrm{~cm}$, testas reticuladas.

Material examinado: Jaíba, 18.XII.1996, E. Tameirão Neto 2271 (BHCB). Leopoldina, 20.X.1998, G. Hatschbach et al. 68659 (MBM Holótipo!, UPCB Isotypus!). Manga, 13.II.1990, R.H.A. Pequeno et al. 
202 (BHCB). Rio Pardo de Minas, 3.II.2014, D.C. Imig et al. 287 (MBM).

Espécie endêmica do Brasil, ocorre em Minas Gerais e possivelmente na Bahia, restrita ao bioma Mata Atlântica, apresenta área de ocupação (AOO) de $12 \mathrm{~km}^{2}$, e não é recoletada desde de 1998 (CNCFlora 2016). Passiflora hatschbachii é morfologicamente muito semelhante à $P$. setacea, especialmente quando em estado vegetativo, porém esta última apresenta somente um par de glândulas no pecíolo, corona de filamentos unisseriada e ovário glabro e glauco. Já $P$. hatschbachii apresenta dois pares de glândulas no pecíolo, e nas flores apresenta duas séries da corona de filamentos e ovário densamente recoberto por tricomas esbranquiçados. Foi avaliada pelo CNCFlora (2016) como EN (em perigo), de acordo com os critérios da IUCN.

33. Passiflora hypoglauca Harms, Repert Sp. Nov. 18: 296. 1922.

Trepadeiras herbáceas a subherbáceas, velutinas. Caules cilíndricos. Estípulas ovaladas a subreniformes, 0,5-1,1 $\times 0,3-0,5 \mathrm{~cm}$, margens glandular-denticuladas. Folhas com pecíolos (0,4-)1,5-2,8 cm compr., 2 glândulas estipitadas; lâminas foliares simples, lanceoladas a oblongolanceoladas, 4,5-8 × 1,5-2,8 cm, ápice agudo a obtuso, mucronado, base arredondada, margens inteiras, ciliar glandular na base. Brácteas ovaladas a oval-lanceoladas, 0,8-2,3 × 0,5-1,2 cm, margem gandular-denteada. Pedúnculos solitários, 3,5-5,5 cm compr.; pedicelo 0,3-0,5 cm compr. Flores 3,8-4,5 cm diâm.; tubo do cálice campanulado 0,4-0,5 × 0,6-1 cm; sépalas oblongo-lanceoladas, 1,5-2 × 0,3-0,5 cm, aristada; pétalas oblongolanceoladas, 1,7-2,2 × 0,4-0,5 cm; corona de filamentos 3 séries, uma série externa filiformes, 0,6-1 cm compr., série seguinte filiformes 0,3-0,4 $\mathrm{cm}$ compr., série interna capilares, ca. $0,1 \mathrm{~cm}$ compr.; androginóforo 0,8-1 cm compr.; ovário elipsoide, piloso. Frutos bagas, ovaladas, 1,8-3,3 $\times$ 1,5-2,5 cm; sementes oblongas a obovadas, $0,3-0,4$ $\times$ ca. $0,2 \mathrm{~cm}$, testas foveoladas.

Material examinado: Catas Altas, Serra do Caraça, 26.IV.2004, R.C. Mota 2922 (BHCB). Conceição do Mato de Dentro, 23.IV.2003, R.C. Mota 2926 (BHCB); 24.XII.2002, R.C. Mota 2925 (BHCB, UPCB). Santa Luzia, 4.II.1938, M. Barreto 8969 (BHCB). Serra da Piedade, 2.II.1866, E. Warming 1169 (G).

Espécie endêmica de Minas Gerais, apresentando extensão de ocorrência (EOO) de $3.692 \mathrm{~km}^{2}$ e AOO de $36 \mathrm{~km}^{2}$, em função do aumento da frequência dos incêndios, turismo desordenado, invasão de espécies exóticas, mineiração e pecuária (CNCFlora 2016). Passiflora hypoglauca é morfologicamente relacionada à $P$. foetida var. foetida e P. boticarioana. Passiflora foetida difere por apresentar folhas trilobadas, cobertas por tricomas viscosos nos caules, folhas e estípulas. Passiflora boticarioana possui estípulas pinatissectas, brácteas ovaladas a oval-lanceoladas, pinatissectas, ovário glabro e tricomas não viscosos. Passiflora hypoglauca possui estípulas semi-ovaladas, inteiras e denteadas na margem, brácteas lanceoladas e margens denteadas, ovário piloso e tricomas não viscosos. As ilustrações da espécie podem ser encontradam em Cervi (2000, p. 103, fig. 4) e Vitta \& Pirani (2015, p. 31, fig. 1hi). Foi avaliada pelo CNCFlora (2016) como EN (em perigo), de acordo com os critérios da IUCN.

34. Passiflora kermesina Link \& Otto, Ver. Gartenb. Preuss. 2: 403, tab. 15. 1826.

Trepadeiras herbáceas, completamente glabras. Caules cilíndricos. Estípulas subreniformes, $0,5-1,5 \times 0,3-0,7 \mathrm{~cm}$. Folhas com pecíolos 3,5-6 cm compr., 2-4 glândulas longo-estipitadas; lâminas foliares simples, trilobadas, 5-7,3 $\times 4-6,5 \mathrm{~cm}$, lobos oblongos a oblongos-lanceolados, ápice obtuso a agudo-acuminado, base truncada e subpeltada, margens inteiras, 2-4 glândulas estipitadas nos sinus dos lobos. Brácteas lineares, 0,4-0,8 cm compr. Pedúnculos solitários, $8-15(-23) \mathrm{cm}$ compr.; pedicelo 0,4-0,8 cm compr. Flores 8-11 cm diâm., tubo do cálice longo-campanulado, 0,8-1 $\times 0,6-1 \mathrm{~cm}$; sépalas oblongo-lanceoladas, 4-5,5 × 0,5-0,8 cm; pétalas oblongo-lanceoladas, 4,3-5,8 $\times 0,5-1 \mathrm{~cm}$; corona de filamentos 3 séries, duas séries externas filiformes, 1-1,5 cm compr., série seguinte filiformes com ápice capitado, 0,4-0,8 cm compr.; androginóforo 2,2-2,5 cm compr.; ovário elíptico, glabro e glauco. Frutos bagas, elípticas, 5-6,5 × 3-3,5 cm; sementes não vistas.

Material examinado: Caparaó, São José do Pedro, 15.V.1991, L.S. Leoni et al. 1568 (UPCB); Estação Ecológica da Caratinga, 12.XII.1995, A. Salino 2380 (BHCB). Caratinga, 12.X.2002, F.R. Couto 98 (BHCB). Manhuaçu, 21.XI.1998, A. Salino et al. 4406 (BHCB, UPCB). Marliéria, 1.III.1999, J.A. Lombardi 2506 (BHCB, MBM, UPCB); Malão, 23.III.1984, M.A. Lopes et al. 132 (BHCB). Muriaé, 23.X.1986, R. Simão et al. 216 (BHCB). Novo Cruzeiro, 2.X.2004, J.R. Stehmann et al. 3529 (BHCB). Pedra do Anta, 13.II.2000, G.E. Valente et al. 437 (UPCB, VIC). Raul Soares, 28.III.1998, A. Salino 4128 (BHCB, UPCB). 
Espécie endêmica do Brasil, sendo restrita ao Sudeste, nos estados do Espírito Santo, Minas Gerais, Rio de Janeiro, Caatinga, Cerrado e Mata Atlântica (BFG 2015; Flora do Brasil 2020). Passiflora kermesina é morfologicamente relacionada à $P$. edmundoi, especialmente vegetativamente. Porém, as flores de $P$. edmundoi possuem um anel membranáceo interno à corona de filamentos, essa membrana excede o tubo do cálice, ficando visivelmente exposta, ainda, as brácteas de $P$. edmundoi são alternas, dispersas a partir da porção mediana do pedúnculo, de coloração rósea e são persistentes, enquanto em P. kermesina, as brácteas são lineares e verticiladas, porém situadas a ca. de $1 \mathrm{~cm}$ do tudo do cálice e cedo decíduas. As ilustrações da espécie podem ser encontradas em Masters (1872, fig. 126), Sacco (1980, p. 72, fig. 17) e Farinazzo \& Salimena (2007, p. 829, fig. 2d-g).

35. Passiflora loefgrenii Vitta, Novon 7: 210-212. 1997.

Trepadeiras herbáceas, glabras. Caules cilíndricos. Estípulas reniformes, 1-1,5 × 0,8-3 $\mathrm{cm}$, pinatissectas, margens inteiras a glandularserreadas na base. Folhas com pecíolos $2-5,5 \mathrm{~cm}$ compr., 6 glândulas estipitadas $0,1-0,2$ cm compr.; lâminas foliares simples, trilobadas, 5-7,5 × 8,8-12 $\mathrm{cm}$, lobos oval a oval-lanceoladas, ápice agudo, base cordada a subpeltada, margens inteiras, 2-4 glândulas nos sinus dos lobos. Brácteas ovaladas a oval-lanceoladas, $1-1,8 \times 0,5-0,9 \mathrm{~cm}$, margensglandular serreadas. Pedúnculos solitários, $8-11 \mathrm{~cm}$ compr.; pedicelo $0,5-1 \mathrm{~cm}$ compr. Flores $8-11,2 \mathrm{~cm}$ diâm.; tubo do cálice campanulado $0,7-1 \times 1-1,5$ $\mathrm{cm}$; sépalas oblongo-lanceoladas, 3,5-5 × 0,9-1,4 $\mathrm{cm}$, aristadas; pétalas oblongo-lanceoladas, 3,3-5 $\times 0,9-1,2 \mathrm{~cm}$; corona de filamentos 6-7-séries, 4-5 séries externas filiformes, 1-1,4 cm compr., 1-2 séries internas dentiformes; androginóforo 2,5-3,2 cm compr.; ovário elipsoide, glabro e glauco. Frutos bagas, elipsoides, 5,5-6,5 × 3,8-4,5 cm; sementes obovadas, $0,4-0,5 \times$ ca. $0,3 \mathrm{~cm}$, testa foveolada.

Material examinado: Caiana, 21.XII.1989, L.S. Leoni 1025 (UPCB).

Espécie endêmica da Brasil, restrita ao Sudeste, onde ocorre nos estados de Minas Gerais e São Paulo e Região Sul nos estados do Paraná e Santa Catarina, em floresta Atlântica (BFG 2015). Passiflora loefgrenii é muito semelhante a $P$. amethystina, especialmente vegetativamente. As duas espécies distinguem- se pela estrutura e coloração das flores: $P$. amethystina apresenta os filamentos radiados e filamentos externos de tamanho semelhantes ao tamanho do perianto, o perianto é roxo ou violeta, o ovário é piloso. Passiflora loegrenii possui os filamentos externos e internos congestos ao redor do androginóforo, de tamanhos semelhantes e que não ultrapassam a metade do tamanho do perianto, o perianto é purpura com corona de filamentos violeta, o ovário é glabro.

36. Passiflora malacophylla Mast. Fl. bras. 1391: 604, tab. 117, fig. 1872.

Trepadeiras herbáceas a subherbáceas, pilosas. Caules cilíndricos. Estípulas lineares 0,1-0,2 cm compr., margens glandular-serreadas a pinatissectas. Folhas com pecíolos $1,2-2,8$ cm compr., 2 glândulas sésseis; lâminas foliares simples, ovaladas a oval-lanceoladas, 4,5-12 $\times$ 2,5-5,8 cm, ápice agudo, glandular-mucronado, base arredondada a subcordada, margens glandularserrilhadas. Brácteas ovaladas, oval-lanceoladas ou oblongas, $1-2,5 \times 0,8-1,2 \mathrm{~cm}$, margens glandulardenteadas. Pedúnculos solitários, 1,5-3,5 cm compr.; pedicelo $0,3-0,5 \mathrm{~cm}$ compr. Flores $4,8-8,5$ cm diâm.; tubo do cálice campanulado $0,5-0,8 \times$ $0,8-1 \mathrm{~cm}$; sépalas oblongas a oblongo-lanceoladas, 2,5-3,8 $\times 0,8-0-1,2 \mathrm{~cm}$, aristadas; pétalas oblongolanceoladas, 2,6-4 × 0,8-1,2 cm; corona de filamentos multisseriada, série externa filiformes, 1-2,3 cm compr., 4-7 séries seguintes capilares, justapostos, 0,3-0,4 cm compr.; androginóforo 0,8-1,5 cm compr.; ovário oblongo, tomentoso. Frutos bagas, oblongas, 3,3-6 × 2,5-3,5 cm; sementes não vistas.

Material examinado: Almenara, 29.II.2004, J.A. Lombardi et al. 5.669 (BHCB, UPCB). Pedro Teixeira, 31.XII.1972, L. Krieger 11.985 (UPCB, HFJF). Salto da Divisa, 19.II.2003, J.A. Lombardi et al. 5037 (BHCB, UPCB).

Espécie endêmica do Brasil, ocorre nos estados da Bahia, Espírito Santo, Minas Gerais, Rio de Janeiro, São Paulo e na Região Sul, há registros apenas para Santa Catarina (BFG 2015; Flora do Brasil 2020). Foi avaliada pelo CNCFlora (2016) como LC (menos preocupante), de acordo com os critérios da IUCN. Passiflora malacoplylla é facilmente reconhecida entre as outras espécies de Passiflora de Minas Gerais por apresentar folhas inteiras e margens serradas, pecíolos com duas glândulas sésseis e flores alvas com corona de filamentos e múltiplas séries, sendo as duas externas radiados e às vezes podendo apresentar uma faixa azul arroxeada próximo à base, em 
material fresco. As ilustrações da espécie podem ser encontradas em Masters (1872, fig. 117 II) e Sacco (1980, p. 51, fig. 11).

37. Passiflora marginata Mast., Fl. bras. 13pt. 1603. 1872.

Trepadeiras herbáceas a subherbáceas, glabras. Caules cilíndricos. Estípulas lineares $0,3-0,5 \times 0,1 \mathrm{~cm}$. Folhas com pecíolos $0,5-1,5$ cm compr., glândulas ausentes; lâminas foliares simples, oblongo-lanceoladas, 6-10 × 2-3,5 cm, ápice agudo, base cordada, margens inteiras. Brácteas oval-lanceoladas, $0,5-0,9 \times 0,4-0,5$ $\mathrm{cm}$, margens inteiras. Pedúnculos solitários, $1-1,5 \mathrm{~cm}$ compr., pedicelos $0,5-0,6 \mathrm{~cm}$ compr. Flores 3-5,3 cm diâm.; tubo do cálice curtocampanulado a pateliforme, $0,5-0,7 \times 1-1,3 \mathrm{~cm}$; sépalas oblongas, $1,5-1,8 \times 0,5-0,7 \mathrm{~cm}$, aristadas; pétalas oblongas a oblongo-lanceoladas, 1,5-1,9 $\times 0,5-0,6 \mathrm{~cm}$; corona de filamentos 5 séries, duas séries externas filiformes, 1,3-1,7 cm compr., as três séries seguintes capilares, $0,1-0,2 \mathrm{~cm}$ compr.; androginóforo 0,9-1 cm compr.; ovário elipsóide, glabro. Frutos bagas, arredondadas, $2-3 \times 2-3 \mathrm{~cm}$.; sementes obovadas, $0,3-0,4 \times 0,3-0,3 \mathrm{~cm}$, testas foveoladas.

Material examinado: Catas Altas, RPPN Santuário da Caraça, 26.IV.2009, C.T. Oliveira et al. 463 (BHCB). Serra da Caraça, 8.V.2003, R.C. Mota 2924 (BHCB).

Espécie endêmica do Brasil ocorrendo nos estados de Minas Gerais, Rio de Janeiro e São Paulo em Floresta Atlântica (BFG 2015; Flora do Brasil 2020). Passiflora marginata é morfologicamente relacionada à $P$. silvestris (citada frequentemente em trabalhos pelo sinônimo: Passiflora galbana Mast.), porém essa última difere-se por apresentar duas glândulas no pecíolo e corona de filamentos em duas séries, enquanto $P$. marginata não apresenta glândulas no pecíolo e a corona de filamentos é composta de 5 séries. As ilustrações da espécie podem ser encontradas em Bernacci et al. (2003, p. 263, fig. 1p) e Mezzonato-Pires et al. (2013, p. 131, fig. 2a).

38. Passiflora mediterranea Vell., Fl. Flumin. 9: tab. 72.1827.

Trepadeiras herbáceas a subherbáceas, glabras ou parcialmente pilosas. Caules cilíndricos. Estípulas reniformes a subreniformes, 1,5-3(-4) $\times 0,7-1,5(-2) \mathrm{cm}$. Folhas com pecíolos $1,5-4 \mathrm{~cm}$ compr., 2-5 glândulas; lâminas foliares simples, oval-lanceoladas a oblongo-lanceoladas, 6-12(-15) $\times 3,5-7,5 \mathrm{~cm}$, ápice agudo, base arredondada, margens inteiras. Brácteas ovaladas a oblongas, $1-2,3 \times 1-1,8 \mathrm{~cm}$. Pedúnculos aos pares, 2,5-7 cm compr., pedicelos $0,4-0,8 \mathrm{~cm}$ compr. Flores 3-4,5 cm diâm; tubo do cálice curto-campanulado a pateliforme $0,8-1,2 \times 0,3-0,6 \mathrm{~cm}$; sépalas oblongas, $1,5-2 \times 0,5-0,7 \mathrm{~cm}$., aristadas; pétalas oblongas a oblongo-lanceoladas, $1,3-1,8 \times$ 0,5-0,6 cm; corona de filamentos 3 séries, uma série externa filiformes, $1-1,5 \mathrm{~cm}$ compr., as duas séries seguintes, filiformes a capilares, $0,2-0,4 \mathrm{~cm}$ compr., ápice capitado; androginóforo $0,7-1 \mathrm{~cm}$ compr.; ovário ovoide a subgloboso, viloso. Frutos bagas, globosas a subglobosas, 3-4,8 cm diâm.; sementes ovaladas a oblongas, $4,5-5 \times 2,5-3 \mathrm{~cm}$, testas alveoladas.

Material examinado: Alto Caparaó, 14.VI.1991, G. Hatschbach 67072 (MBM); 8.III.2010, J. Cordeiro \& J.M. Silva 3545 (MBM). Andrelândia, 3.I.2013, D.C. Imig 122 (MBM,UPCB). Arantina, 3.I.2013, D.C. Imig 111 (MBM, UPCB). Caparaó, 24.X.1989, J.R. Pirani et al. 2548 (BHCB). Catas Altas, 13.II.2005, R.C. Mota 2756 (BHCB). Carangola, Serra do Gramma, 27.I.1930, Y. Mexia 4251 (S); 14.IV.1935, J.G. Kuhlmann 65 (VIC). Espera Feliz, 4.III.2010, M.O. Bunger et al. 310 (BHCB). Estouro, 13.II.1985, W.N. Vidal et al. 600 (VIC). Novo Cruzeiro, 2.X.2004, J.R. Stehmann et al. 3583 (BHCB). Santa Barbara, 13.XII.1978, H.F. Leitão Filho et al. 9618 (MBM, UEC).

Espécie endêmica do Brasil, com distribuição nos estados do Espírito Santo, Minas Gerais, Rio de Janeiro, São Paulo, Paraná e Santa Catarina, em Floresta Atlântica (BFG 2015; Flora do Brasil 2020). Passiflora mediterranea é facilmente distinta das demais espécies ocorrentes em Minas Gerais por apresentar brácteas róseas e persistentes no fruto. É citada frequentemente em trabalhos pelo sinônimo: Passiflora jilekii Wawra. As ilustrações da espécie podem ser encontradas em Sacco (1980, p. 57, fig. 13), Cervi (1992, p. 20, fig. 3-4), Cervi (1997, p. 57, fig. 5) e Mezzonato-Pires et al. (2013, p. 131 , fig. $2 b-c)$.

39. Passiflora mendoncaei Harms, Repert. Sp. Nov. 18: 297. 1922.

Trepadeiras herbáceas, glabras. Caules cilíndricos. Estípulas ovaladas a subreniformes, $1,5-2,3 \times 0,8-1,3 \mathrm{~cm}$. Folhas com pecíolos 2-3,4 cm compr., 2 glândulas; lâminas foliares simples, inteiras, trilobadas, às vezes brevemente trilobadas, 3,5-5,5 × 1,8-3,5 cm, lobos oblongos ou obovados, ápice agudo, base arredondada a cordada, margens inteiras. Brácteas ovaladas, oval-lanceoladas ou oblongas, $2-3,5 \times 1-2,3 \mathrm{~cm}$. Pedúnculos 7-10,5(-13) cm; pedicelos 0,5-0,7 
com compr. Flores 7,5-10 cm diâm.; tubo do cálice tubular, 1,8-2,5 × 0,9-1,3 cm; sépalas oblongo-lanceoladas, 3,5-4,2 × 0,6-0,8 cm, aristas, reflexas; pétalas oblongo-lanceoladas, 3-4 $\times 0,5-0,7 \mathrm{~cm}$, reflexas; corona de filamentos $2(-3)$ séries, uma série externa liguliformes, 0,7-0,9 cm compr., série seguinte filiformes, 0,3-0,4 cm compr., terceira série quando presente, filiformes, 0,2-0,3 cm compr.; androginóforo 3,7-4,3 cm compr.; ovário elipsoide a oblongo, glabro. Frutos bagas, globosas a subglobosas, 2,5-3,2 × 2,3-3 $\mathrm{cm}$; sementes não vistas.

Material examinado: Camanducaia, 19.X.2001, L.C. Melo 164 (BHCB); 22.X.2001, J.R. Stehmann et al. 2999 (BHCB); 20.VI.2002, L.H.Y. Kamino et al. 22 (BHCB, UPCB); Mata do Atair, 26.XI.2004, G.S. França et al. 654 (BHCB, UPCB). Delfin Moreira, 21.III.2011, L.L. Giacomin et al. 1558 (BHCB).

Espécie endêmica do Brasil, ocorre nos estados de Minas Gerais, Rio de Janeiro, São Paulo, Paraná e Santa Catarina (BFG 2015). Passiflora mendoncaei pode ser confundida com $P$. trintae, pois ambas apresentam as flores de coloração purpúreas e tubo do cálice tubular, porém esta última apresenta seis glândulas nos pecíolos, enquanto $P$. mendoncaei apresenta apenas duas glândulas. A ilustração da espécie pode ser encontrada em Sacco (1980, p. 98, fig. 24).

40. Passiflora miersii Mast., Fl. bras. 13(1): 561, 599 (1872).

Trepadeiras herbáceas, totalmente glabras. Caules cilíndricos. Estípulas reniformes, 0,8-2 $\times 0,5-1,2 \mathrm{~cm}$. Folhas com pecíolos 1,5-2 cm compr., 2 glândulas; lâminas foliares simples, ovaladas ou oval-lanceoladas, $3-6,5 \times 1,8-3$ $\mathrm{cm}$, ápice agudo, base arredondada, margens inteiras. Brácteas lineares, 0,2-0,4 × ca. 0,1 cm. Pedúnculos solitários, 2,5-6 cm compr.; pedicelo 0,2-0,3 cm compr. Flores 4-4,5 cm diâm.; tubo do cálice campanulado, 0,4-0,5 × 0,4-0,6 cm; sépalas oblongas, $1,5-2,5 \times 0,5-0,8 \mathrm{~cm}$, aristadas; pétalas oblongas, $1,3-2,3 \times 0,5-0,7 \mathrm{~cm}$; corona de filamentos 4 séries, duas externas filiformes, $1-1,5 \mathrm{~cm}$ compr., $3^{\mathrm{a}}$ serie filiformes, 0,5-0,6 cm compr., $4^{\mathrm{a}}$ série capilares, 0,2-0,3 cm compr.; androginóforo 1,5-2 cm compr.; ovário ovoide, glabro e glauco. Frutos bagas, obovóides ou elípticas, 3-4,3 × 1,5-2,5 cm; sementes ovaladas, $0,2-0,3 \times 0,1-0,2 \mathrm{~cm}$, testas reticuladas.

Material examinado: Rio de Janeiro, J.F. Widgren 328, 1845 (MO 100237772); Gardner (MB Holotypus!). Aiuruoca, 29.XII.2012, D.C. Imig \& D.M. Bressan 97 (UPCB, MBM, CTBA); Vale do Matutu, 10.X.2004, R.C.
Motta et al. 2498 (BHCB). Almenara, 28.II.2004, J.A. Lombardi et al. 5665 (BHCB). Andrelândia, 31.XII.2012, D.C. Imig \& D.M. Bressan 81 (UPCB, MBM). Caldas, 7.XII.1854, A.F. Regnell III 637 (S); 5.II.1876, H. Mosen 4148 (S). Congonhas do Norte, 20.V.1989, G. Hatschbach et al. 52961 (MBM); 10.X.2004, R.C. Mota et al. 2498 (BHCB). Itabirito, 25.I.2007, S.G. Rezende et al. 1937 (BHCB). Juiz de fora, Morro de Imperador, 8.IV.2003, D.S. Pifano et al. 518 (CESJ). Lima Duarte, 2.I.2013, D.C. Imig \& D.M. Bressan 96 (UPCB, MBM). São Vicente de Minas, 2.I.2013, D.C. Imig \& D.M. Bressan 104 (UPCB).

Espécie endêmica do Brasil, distribuída nos estados da Bahia, Sergipe, Distrito Federal, Mato Grosso do Sul, Espírito Santo, Minas Gerais, Rio de Janeiro, São Paulo e Paraná, em vegetação de Caatinga, Cerrado e Mata Atlântica. (BFG 2015; Flora do Brasil 2020). Passiflora miersii é facilmente diferenciável das outras espécies ocorrentes em Minas Gerais por ser uma planta herbácea e apresentar folhas, estípulas e brácteas inteiras, membranáceas e de coloração arroxeada na face abaxial dessas estruturas, além disso, os pedúnculos florais são longos e tênues e curvamse (in vivo) projetando a flor horizontalmente. As ilustrações da espécie podem ser encontradam em Masters (1872, fig. 117 I) e Vitta \& Pirani (2015, p. 35 , fig. $2 a-b)$.

41. Passiflora odontophylla Harms ex Glaziou, Bull. Soc. Bot. France 56, Men. 3d: 315, 1938.

Trepadeiras herbáceas, glabras. Caules cilíndricos, subangulares ou complanadas. Estípulas setáceas, 0,5-1 × ca. $0,1 \mathrm{~cm}$. Folhas com pecíolos (1,5-)2-4 cm compr., 2 glândulas sésseis; lâminas foliares simples, ovaladas a oval-lanceoladas, 7,5$11 \times 2,8-4,8 \mathrm{~cm}$, ápice agudo, base arredondada, margens inteiras. Brácteas ovaladas a ovallanceoladas, 1,2-3,7 × 0,9-1,6 cm. Pedúnculos solitários, 3,5-5,5 cm compr. Flores 4,8-7,5 cm diâm; tubo do cálice campanulado, 0,7-0,9 × 0,6-1 cm; sépalas oblongo-lanceoladas, 2,5-3,1 × 0,7-1,2 $\mathrm{cm}$, aristadas; pétalas oblongo-lanceoladas, 2,6-3,3 $\times$ 0,8-1,3 cm; corona de filamentos multisseriada, duas séries externas filiformes, 1,6-3 cm compr., 3-4(-5) séries seguintes capilares, 0,4-0,5 cm compr.; androginóforo 1,5-2,3 cm compr., uma tróclea na altura do opérculo; ovário globoso a subgloboso, glabro. Frutos bagas, subglobosas, $2,8-5,3 \times 2,5-2 \mathrm{~cm}$; sementes não vistas.

Material examinado: Caratinga, 21.I.1985, P.M. Andrade et al. 641 (BHCB, MBM). Novo Cruzeiro, 2.X.2004, J.R. Stehmann et al. 3635 (BHCB). Pedro Teixeira, 31.XII.1972, L. Krieger 11985 (BHCB, VIC). 
Passilora odontophylla é endêmica do Brasil, ocorre na Bahia e Rio de Janeiro (BFG 2015; Flora do Brasil 2020). É citada aqui pela primeira vez para o estado de Minas Gerais. Espécie semelhante a $P$. malacophylla especialmente por apresentarem flores brancas com filamentos brancos ou ocasionalmente com uma faixa azulada na base, porém $P$. ondontophylla é vegetativamente glabra e $P$. malacoplylla é pilosa. A ilustração da espécie pode ser encontrada em Nunes \& Queiroz (2006, p. 215, fig. 16a-b).

42. Passiflora recurva Mast., Fl. bras. 13. pt. 1: 608. 1872.

Trepadeiras subherbáceas a lenhosas, glabras. Caules cilíndricos estriados a subangulado. Estípulas lineares, $0,3-0,5 \times$ ca. $0,1 \mathrm{~cm}$. Folhas com pecíolos 1,5-2,5 cm compr., 2 glândulas orbiculares, sésseis; lâminas foliares simples, trilobadas, 3-5,5 × 2,5-4,5 cm, lobos oblongos, lobos laterais ascendentes, ápice obtuso, base cordada, margens inteiras. Brácteas oblongolanceoladas, $0,8-1,5 \times 0,5-0,8 \mathrm{~cm}$. Pedúnculos solitários, 4,5-10 cm compr. Flores 4,5-5,2 cm diâm; tubo do cálice campanulado, $0,8-1,2 \times 1-1,2$ $\mathrm{cm}$; sépalas oblongo-lanceoladas 1,5-2 ×0,6-1 cm, aristadas; pétalas oblongo-lanceoladas, 1,5-2,1 $\times 0,6-1 \mathrm{~cm}$; corona de filamentos 2 séries, série externa filiformes, 1-1,2 cm compr., série interna capilares, 3-4 cm compr.; androginóforo 1,5-2,5 cm compr.; ovário elipsoide, glabro e glauco. Frutos bagas, oblongas a elipsoides, 4-5,5 × 2,5-5,3 cm; sementes ovaladas, $0,4-0,6 \times 0,2-0,3 \mathrm{~cm}$, testas reticuladas.

Material examinado: Diamantina, 23.X.1999, A.C. Cervi et al. 6904 (MBM). Francisco de Sá, 26.XI.1984, R.M. Harley et al. 6425 (MBM). Grão Mogol, 13.XII.1989, J.T. Pirani et al. 12686 (MBM). Itacambira, 10.IV.2005, E. Tameirão Neto 4187 (BHCB). Juramento, 17.III.1997, G. Hatschbach et al. 66368 (MBM).

Espécie endêmica do Brasil, restrita aos estados da Bahia, Pernambuco e Minas Gerais, em Cerrado e Mata Atlântica (BFG 2015). Passiflora recurva quando florida apresenta os estames e estigmas projetados para uma mesma direção e sua polinização é realizada por pequenos morcegos, conforme observado por Ulmer \& MacDougal (2004). Esta espécie difere das outras espécies por apresentar folhas trilobadas e margens inteiras e minúsculas estípulas e pedúnculo notadamente curvado na ponta, ainda em fase de botão floral. A ilustração da espécie pode ser encontrada em Vitta (2006, p. 10, fig. 1a-b).
43. Passiflora saccoi Cervi, Brittonia 46(2), 1994.

Trepadeiras herbáceas a subherbáceas, glabras. Caules cilíndricos. Estípulas reniformes a subreniformes $2-3 \times 1-1,7 \mathrm{~cm}$. Folhas com pecíolos 3,5-5 cm compr., 4-6 glândulas estipitadas; lâminas foliares simples, trilobadas, 5-6 × 5-10 $\mathrm{cm}$, lobos oval-lanceolados, ápice agudo, base cordada, margens inteiras. Brácteas ovaladas, 1,7-2 × 1-1,3 cm. Pedúnculos solitários, 2-2,5 cm compr.; pedicelos $0,2-0,3 \mathrm{~cm}$ compr. Flores $4-4,5$ $\mathrm{cm}$ diâm; tubo do cálice campanulado, 0,3-0,4 $\times 0,3-0,5 \mathrm{~cm}$; sépalas lanceoladas, $1,5-1,7 \times$ $0,4-0,5 \mathrm{~cm}$, aristadas; pétalas lanceoladas, $1,2-1,3$ $\times 0,3-0,4 \mathrm{~cm}$; corona de filamentos 3 séries, serie externa filiformes, $0,8-1 \mathrm{~cm}$ compr., séries internas capilares, 0,1-0,2 cm compr.; androginóforo $0,5-0,8 \mathrm{~cm}$ compr.; ovário ovoide, glabro e glauco. Frutos bagas, globosos, ca. 4 cm diâm.; sementes ovaladas, ca. 0,3 cm compr., testas foveoladas.

Material examinado: Lagoa Preta, margem do Rio Paraopeba, E.P. Heringer 6467 (UPCB Holotypus!, M Isotypus!).

Passiflora saccoi é endêmica de Minas Gerais e foi avaliada pelo CNCFlora (2016) como DD (dados insuficientes), de acordo com os critérios da IUCN. Espécie morfologimente muito semelhante a P. eichleriana e $P$. tenuifila, sendo possível apenas a identificação em estado reprodutivo. Passiflora eichleriana apresenta em suas flores, 6 séries de filamentos da corona e esses são completamente alvos, enquanto $P$. tenuifila apresenta 4 séries na corona de filamentos e as duas séries externas são arroxeadas e $P$. saccoi apresenta três series na corona de filamentos e estes são alvos.

\section{Passiflora setacea DC. Prodr. 3: 329. 1828.}

Trepadeiras herbáceas a subherbáceas, pilosas. Caules cilíndricos. Estípulas setáceas, 0,4$0,5 \times$ ca. $0,1 \mathrm{~cm}$. Folhas com pecíolos $1,5-3,5 \mathrm{~cm}$ compr., 4 glândulas orbiculares; lâminas foliares simples, trilobadas, raramente inteiras ou bilobadas no mesmo exemplar, 5-11 ×4,5-12 cm, lobos ovallanceolados a oblongo-lanceolados, ápice agudoapiculado, base arredondadas, margens serreadas. Brácteas ovaladas a oval-lanceoladas, $0,8-2,5 \times$ 0,5-1,3 cm. Pedúnculos solitários, $(2,5-) 6,5-13 \mathrm{~cm}$ compr.; pedicelos ca. 1,3 cm compr. Flores 5,5-9,5 cm diâm; tubo do cálice campanulado, 0,8-1,5 × 1-1,3 cm; sépalas oblongo-lanceoladas 2,5-4 $\times$ $0,8-1,5 \mathrm{~cm}$, aristadas; pétalas oblongo-lanceoladas, $2,4-3,8 \times 0,7-1,1 \mathrm{~cm}$; corona de filamentos unisserida, filamentos filiformes, $1-1,5 \mathrm{~cm}$ compr.; androginóforo 1,5-2,8 cm compr.; ovário elipsóide, 
glabro e glauco. Frutos bagas, oblongas a ovaladas, 4-5,5 × 2,5-5,3 cm; sementes ovaladas, 0,4-0,5 $\times$ $0,2-0,3 \mathrm{~cm}$, testas reticuladas.

Material examinado: Almenara, 28.II.2004, J.A. Lombardi et al. 5641 (BHCB). Caratinga, 28.IX.1984, P.M. Andrade et al. 439 (BHCB). Capitão Enéas, 6.VI.2010, A.C. Cervi et al. 9678 (MBM); 20.VIII.2002, G. Hatschbach et al. 73672 (MBM); Janaúna, 3.II.2014, D.C. Imig et al. 286 (MBM). Francisco Sá, 18.V.1988, G. Hatschbach et al. 52484 (MBM). Leopoldina, 9.VIII.1983, G. Hatschbach et al. 46811 (MBM). Montes Claros, 4.VIII.1988, A.M. Carvalho et al 6583 (UPCB); 15.VI.1990, G. Hatschbach 54307 (MBM, S); 6.VI.2010, A.C. Cervi et al. 9660 (MBM). Novo Cruzeiro, 2.X.2004, J.R. Stehmann et al. 3537 (BHCB, UPCB). Rio Vermelho, Distrito de Pedra Menina, 26.VIII.2008, N.F. Motta et al. 1383 (UPCB).

Espécie endêmica do Brasil, ocorre nos estados de Alagoas, Bahia, Distrito Federal, Goiás, Mato Grosso, Espírito Santo, Minas Gerais e Rio de Janeiro, no Cerrado, Caatinga e Mata Altântica (BFG 2015; Flora do Brasil 2020). Passiflora setacea é morfologicamente relacionada à $P$. hatschbachii, porém essa última diferencia-se por apresentar duas séries de filamentos na corona, dois pares de glândulas no pecíolo e ovário piloso, coberto por tricomas esbranquiçados. Enquanto $P$. setace a apresenta corona de filamentos unisseriada, um par de glândulas no pecíolo e ovário glabro. As ilustrações da espécie podem ser encontradas em Masters (1872, fig. 124), Nunes \& Queioz (2006, p. 220, fig. 19a-b) e Milward-de-Azevedo (2007a, p. 77 , fig. $3 \mathrm{a}-\mathrm{g})$.

45. Passiflora setulosa Killip, Publ. Field Mus. Nat. Hist. Bot. Ser. 19(2): 515. 1938.

Trepadeiras herbáceas, pilosas, tricomas setulosos. Caules cilíndricos. Estípulas ovaladas a oval-lanceoladas, $0,3-0,5 \times 0,2-0,4 \mathrm{~cm}$. Folhas com pecíolos 1-1,8 cm compr., 2-4(-6) glândulas estipitadas; lâminas foliares simples, profundamente trilobadas, 5,5-8,5 ×5-9 cm, lobos oblongo-lanceolados a lanceolados, lobos laterais divaricados, ápice mucronado, base arredondada, margens inteiras. Brácteas ovaladas, 0,3-0,4 × ca. $1 \mathrm{~cm}$. Pedúnculos solitários, 2,5-3,5 cm compr.; pedicelos ca. 0,3 cm compr. Flores 2,3-3 cm diâm; tubo do cálice pateliforme, 0,2-0,4 × 0,8-1 cm; sépalas oblongas, $0,8-1,3 \times 0,3-0,4 \mathrm{~cm}$, aristadas; pétalas oblongo-lanceoladas, $0,8-1,4 \times 0,3-0,5 \mathrm{~cm}$; corona de filamentos 3 séries, duas séries externas filiformes, 1-1,4 cm compr., série interna capilares, 0,2-0,3 cm compr.; androginóforo 0,6-0,8 cm compr.; ovário subgloboso, densamente piloso.
Frutos bagas, elipsóides ou ovóides, 3-4 × 2,5-3 $\mathrm{cm}$; sementes ovaladas, $0,3-0,5 \times 0,2-3 \mathrm{~cm}$, testas lisas, com 7 proeminências do ápice.

Material examinado: Camanducaia, 24.X.2007, J.R. Stehmann et al. 4789 (BHCB). Ingaí, D.C. Imig et al. 295 (ACCH, MBM). São João Del Rey, 13.II.2011, $M$. Sobral 13759 (HUFSJ).

Espécie endêmica do Brasil, ocorre nos estados de São Paulo e Paraná (BFG 2015; Flora do Brasil 2020), e apresenta AOO de 40 $\mathrm{km}^{2}$ (CNCFlora 2016). É citada pela primeira vez para o estado de Minas Gerais. Passiflora setulosa é bem circunscrita em relação às outras espécies que ocorrem no estado, especialmente por apresentar lâminas trilobadas com lóbulos oblongos lanceolados a lanceolados e os lóbulos laterais ascendentes, estípulas ovaladas, simétricas e profundamente denteadas a laceradas. É relacionada com $P$. campanulata, mas essa apresenta lâminas com lóbulos oblongos e os laterais são divaricados, estípulas reniformes, assimétricas de margens denteadas glandulares. As flores são muito semelhantes nas duas espécies e ambas apresentam 3 séries de filamentos da corona. As ilustrações da espécie podem ser encontradas em Cervi (2000, p. 101, fig. 3) e Bernacci et al. (2003, p. 267, fig. 2c-d).

46. Passiflora silvestris Vell., Fl. Flumin. 9: pl. 74. 1831.

Trepadeiras herbáceas a suberbáceas, glabras. Caules cilíndricos. Estípulas ovaladas a ovallanceoladas $2-2,8 \times 0,9-1,6 \mathrm{~cm}$. Folhas com pecíolos 1,5-2,8 cm, 2 glândulas opostas; lâminas foliares simples, ovaladas a oblongas, raramente oblongo-lanceoladas, 6-12 × (2,3-)3,5-6,3 cm, ápice obtuso, base arredondada a cordada, margens inteiras. Brácteas ovaladas, oval-lanceoladas ou oblongo-lanceoladas, $(1-) 2-3,3 \times(0,5-) 1-1,8$ $\mathrm{cm}$. Pedúnculos solitários, às vezes congestos no ápice de ramos, 4,5-8,5 cm compr; pedicelos ca. $1 \mathrm{~cm}$ compr. Flores 7-8,5 cm diâm; tubo do cálice campanulado, 0,8-1,2 × 1-1,3 cm; sépalas oblongolanceoladas, 3-3,5 ×0,5-0,7 cm, aristadas; pétalas oblongo-lanceoladas, 3-3,8 × 0,5-0,8 cm; corona de filamentos 2 séries, série externa filiformes, $1-1,5 \mathrm{~cm}$, série seguinte filiformes $0,4-0,5 \mathrm{~cm}$; androginóforo 1,8-2,5 cm compr.; ovário elipsóide, glabro. Frutos bagas, oblongos, 4,8-6 × 2,8-3,5 $\mathrm{cm}$; sementes obovadas, $0,3-0,35 \times 0,2-0,25 \mathrm{~cm}$, testas foveoladas.

Material examinado: Belo Horizonte, 9.VI.1934, M. Barreto 873 (BHCB). Canaão, 9.VIII.1986, M.F. 
Vieira et al. 425 (VIC). Central de Minas, 22.07.1986, Pedralli et al. 2652 (BHCB). Cristália, 10.II.1991, G. Hatschbach et al. 55032 (MBM); Fazenda da Tabunha, 31.VIII.1930, Y. Mexia 5026 (BM). Francisco Dumont, 16.V.2001, G. Hatschbach et al. 72200 (MBM). Grão Mogol, 21.III.1980, G. Hatschbach 42844 (MBM). Marliéria, 13.VIII.1998, R.C.C. Bortoluzzi et al. 243 (VIC). Pains, Fazenda Amargoso, 29.XII.2004, P.H.A. Melo 1239 (BHCB, UPCB). Salto do Divisa, 20.II.2003, J.A. Lombardi et al. 5097 (BHCB, MBM). São José do Goiabal, 6.VIII.2004, J.R. Stehmann et al. 3739 (BHCB).

Espécie endêmica do Brasil, ocorre nos estados do Alagoas, Bahia, Ceará, Paraíba, Pernambuco, Rio Grande do Norte, Sergipe, Espírito Santo, Minas Gerais, Rio de Janeiro em Cerrado e Mata Atlântica (BFG 2015; Flora do Brasil 2020). Passiflora silvestris é morfologicamente relacionada à $P$. marginata, especialmente vegetativamente, pela forma das folhas, porém essa ultima não apresenta glândulas no pecíolo e a corona de filamentos em 5 séries, enquanto $P$. silvestris difere-se por apresentar duas glândulas no pecíolos e corona de filamentos em duas séries. A ilustração da espécie pode ser encontrada em Vellozo (1831, fig. 74).

\section{Passiflora speciosa Gardn, Sertum Plantarum 1: pl.17. 1843. \\ Fig. $3 f$}

Trepadeiras lenhosas, pilosas, tricomas ferrugíneos. Caules cilíndricos. Estípulas setáceas, 0,4-0,5 cm compr. Folhas com pecíolos 1,8-2,3 cm, 4 glândulas orbiculares; lâminas foliares simples, profundamente trilobadas, raramente 5-lobadas, (2-)5-11,5 × (2,5-)4-7,5 cm, lobos oblongo-lanceolados, lobos laterais ascendentes ou divaricados, ápice agudo, base obtusa, margens serreadas. Brácteas oblongo-lanceoladas ou oblongas, 2,8-4,5 × 1-2,3 cm, 2-4 glândulas orbiculares. Pedúnculos solitários, 4-7,5 cm compr; pedicelos 5-11 cm compr. Flores 10-12,5 cm diâm; tubo do cálice cilíndrico-campanulado, 0,8-1,2 × 0,5-0,8 cm; sépalas oblongo-lanceoladas, 3,8-4,5 $\times 0,8-1,3 \mathrm{~cm}$, aristadas; pétalas oblongolanceoladas, 3,8-4,6 $\times 0,8-1,2 \mathrm{~cm}$; corona de filamentos 2 séries, série externa assovelados, 0,7-1,2 cm compr., série interna filiformes, 0,5-0,8 cm compr.; ovário elipsoide a oblongo, tomentoso. Frutos bagas, oblongas, 5-7,5 × 3,8-4,2 cm; sementes oblongas a obovadas, ca. $0,5 \times 0,3 \mathrm{~cm}$, testas superficialmente reticuladas.

Material examinado: Martius 1081 (M); 1834, Riedel 330 (LE); VII.1842, Gardner 4691 (G). Araponga, 8.X.1986, M.F. Vieira et al. 457 (VIC). Barão de Cocais, 16.XII.2002, A.M. Oliveira et al. 167 (CESJ, BHCB);
3.II.2014, D.C. Imig et al. 298 (ACCH, MBM). Caraça, Caminho da Cascatona, 6.VI.1980, Tales 205 (BHCB). Carangola, 8.III.1991, L.S. Leoni 1584 (UPCB, GFJP). Conceição do Mato Dentro, X.2007, R.M. Castro et al. 1432 (CESJ). Coronel Pacheco, 9.IX.1940, E.P. Heringer 331 (VIC). Descoberto, 26.V.2001, R.M. Castro et al. 405 (CESJ); 9.VI.2001, R.M. Castro et al. 467 (CESJ, SP, BHCB); 1.IX.2001, R.C. Forzza et al. 1847 (CESJ); 13.V.2000, F.R. Salimena et al. 144 (MBM, CESJ); Morro do Gavião, 6.VII.2004, G.S. França \& F. Ragge 603 (BHCB). Ewbank da Câmara, 13.IX.1994, H.G.P. Santos et al. 309 (UPCB, CENARGEN); Fazenda Creciúma, 25.I.1930, Y. Mexia 495 (S, BM, G). Fervedouro, 10.VII.1999, J.A. Lombardi 3114 (BHCB). João Monlevade, 14.IX.1989, P.H.A. Pequeno et al. 07 (MBM, BHCB). Juiz de Fora, 9.VI.2001, R.M. Castro et al. 467 (CESJ); 29.IX.2001, D.S. Pifano \& G. Valente 91 (CESJ); 30.V.2002, D.S. Pifano 370 (MBM CESJ); 8.VII.2006, A.S.M. Souza et al. 238 (CESJ); 29.VII.2006, F.M.F. Viana 195 (CESJ); XI.2007, M. Neto et al. 597 (CESJ). Leopoldina, 10.X.1992, G. Hatschbach et al. 57924 (UPCB, MBM, HFIE). Mariana, 7.IV.2000, R.C. Mota \& L. Viana 568 (BHCB). Marliéria, 14.VII.1993, J.A. Lombardi 297 (BHCB); 11.VII.1999, L.G. Temponi et al. 48 (UPCB, VIC). Novo Cruzeiro, 2.X.2004, J.R. Stehmann et al. 3635 (UPCB, BHCB). Ouro Preto, 30.I.1999, R.C. Mota 27 (BHCB); Parque Nacional do Caparaó, 16.X.1988, L. Krieger et al. 22932 (MBM, UFJF). Pedro Teixeira, 31.II.1972, L. Krieger 11985 (MBM, HFJF, UPCB). Porto Firme, 28.XI.1999, A.E. Marques 230 (VIC). São Gonçalo do Rio Abaixo, VII.2002, J.A. Lombardi \& A. Salino 4908 (BHCB). Santa Leopoldina, Cachoeiro, 21.VII.1978, C. Pereira 866 (RFA). Santa Maria do Salto, 23.VIII.2003, J.A. Lombardi et al. 5414 (BHCB). Santa Tereza, 19.VI.1984, R.M. Pizziolo 154 (UPCB, MBML). São João Napomuceno, 26.X.1958, L. Krieger 16758 (MBM, UFJF, UPCB). Serra Azul de Minas, 22.XI.1997, G. Hatschbach et al. 67403 (MBM). Serra do Caparaó, 20.XI.1988, L. Krieger et al. 535 (UPCB UFJF). Serro, 9.IX.1972, G. Hatschbach 27500 (MBM). Simonésia, 20.III.2009, J.R. Stehman et al. 6026 (BHCB). Soares, Serra do Caparaó, 7.IX.1981, J.M. Ferrari 891 (BHCB). Viçosa, 27.VIII.2006, E.B. Paixão 01 (UPCB, VIC); 19.XII.1929, Y. Mexia 4138 (L, BM, G).

Espécie endêmica do Brasil, e restrita ao Sudeste, nos estados do Espírito Santo, Minas Gerais e Rio de Janeiro (BFG 2015). Passiflora speciosa é distinta das demais espécies ocorrentes em Minas Gerais por apresentar flores vermelhas e tricomas ferrugíneos. As ilustrações da espécie podem ser encontradas em Masters (1872, fig. 120), Farinazzo \& Salimena (2007, p. 829, fig. 2h-m), Mezzonato-Pires et al. (2013, p. 131, fig. 2g-h), Vitta \& Pirani (2015, p. 35, fig. 2h) e Moraes (2016, pág. 81 , fig. $310-s)$. 
48. Passiflora tenuifila Killip, Journ. Wash. Acad. Sci. 17: 430. 1927.

Trepadeiras herbáceas a subherbáceas, glabras. Caules subangulados a cilíndricos. Estípulas reniformes ou subreniformes, $1,5-3,2 \times 0,5-1,7$ $\mathrm{cm}$. Folhas com pecíolos 2,5-5 cm compr., 2-6(-8) glândulas estipitadas; lâminas foliares simples, trilobadas, 5-9 × 5-12 cm, lobos ovalados ou ovalelípticos, ápice arredondado, base cordado, margens inteiras. Brácteas ovaladas, $1-1,8 \times 1-1,5 \mathrm{~cm}$. Pedúnculos solitários, 2,5-6,5 cm compr.; pedicelos ca. $0,35 \mathrm{~cm}$ compr. Flores $4-5 \mathrm{~cm}$ diâm; tubo do cálice pateliforme, $0,8-1 \times 0,3-0,4 \mathrm{~cm}$; sépalas oblongolanceoladas, $1,5-2 \times 0,5-0,6 \mathrm{~cm}$, aristadas; pétalas oblongo-lanceoladas, $1,3-1,8 \times 0,4-0,5 \mathrm{~cm}$; corona de filamentos 4 séries, duas séries externas filiformes, $0,5-0,8 \mathrm{~cm}$ compr., as séries seguintes capilares, $0,1-0,3 \mathrm{~cm}$ compr.; androginóforo $0,8-1 \mathrm{~cm}$ compr.; ovário globoso, glabro, glauco. Frutos bagas, globosas a subglobosas, 5-8 cm diâm.; sementes obovadas, $0,45-0,5 \times 0,2-0,3 \mathrm{~cm}$, testas alveoladas.

Material examinado: Diamantina, 9.XII.1992, H.F. Leitão Filho 27626(HUFU). Lagoa Preta, E.P. Heringer 6467 (NY, MO). Montes Claros, Granja Reunidas, 9.III.1929, J.G. Kuhlmann 113 (RB). Oliveira, XI.2001, L.C. Bernacci \& F.C. Campos Neto 3277 (IAC). Paraopeba, Horto Florestal de Paraopeba, 14.XI.1955, E.P. Heringer 5060 (UnB).

Espécie endêmica do Brasil, ocorre nos estados de Minas Gerais, Rio de Janeiro, São Paulo, Paraná, Rio Grande do Sul e Santa Catarina, em Cerrado e Mata Atlântica (BFG 2015; Flora do Brasil 2020). Passiflora tenuifila é morfologimente muito semelhante a $P$. eichleriana e $P$. saccoi, sendo possível apenas a identificação em estado reprodutivo. Nas flores, apresentam P. eichleriana 6 séries de filamentos da corona e esses são completamente alvos, enquanto $P$. tenuifila apresenta 4 séries na corona de filamentos e as duas séries externas são arroxeadas. As ilustrações da espécie podem ser encontradas em Sacco (1980, p. 91, fig. 22), Cervi (1997, p. 77, fig. 10) e Deginani (2001, p. 109, fig. 36).

49. Passiflora tetraden Vell., Fl. Flumin. 9, fig. 91. 1831.

Fig. 3e

Trepadeiras subherbáceas a lenhosas, glabras. Caules cilíndricos. Estípulas reniformes 2-2,5 × 1-1,5 $\mathrm{cm}$. Folhas com pecíolos 1,5-2,5 cm compr., 2(-4) glândulas suborbiculares; lâminas foliares simples, inteiras ou superficialmente trilobadas, oblongas, raramente oblongo-lanceoladas, 5-7,2 × (2,3-)3-5,3 $\mathrm{cm}$, ápice agudo a obtuso, base agudo a obtuso, margens inteiras. Brácteas ovaladas a oblongas, $(2-) 3,3-5,3 \times(1-) 1,8-3,5 \mathrm{~cm}$. Pedúnculos solitários, $1,5-2,5 \mathrm{~cm}$ compr.; pedicelos $0,4-0,6 \mathrm{~cm}$ compr.
Flores 6-8,5 cm diâm; tubo do cálice campanulado, $0,8-1 \times 1-1,5 \mathrm{~cm}$; sépalas oblongo-lanceoladas, 2-3,5 × 1-1,3 cm; pétalas oblongo-lanceoladas, 2-3,4 $\times 1-1,2 \mathrm{~cm}$; corona de filamentos 5 séries, duas séries externas liguliformes, $2-3 \mathrm{~cm}$ compr., 3 séries seguintes dentiformes, $0,1-0,3 \mathrm{~cm}$ compr.; androginóforo 1,3-2 cm compr.; ovário ovoide, glabro e glauco. Frutos bagas, globosas, 3,8-6 cm diâm.; sementes obovadas $0,3-0,5 \times 0,2-0,3 \mathrm{~cm}$, testa foveoladas.

Material examinado: Conceição de Ibitipoca, caminho para o P. E. Ibitipoca, 4.I.2013, D.C. Imig 123 (MBM, UPCB). Delfim Moreira, 20.III.2011, R. Fernandes et al. 906 (BHCB). Ressaquinha, 2.XII.1946, A.P. Duarte 734 (M). Viçosa, 30.VI.1995, G.E. Valente 33 (UPCB, VIC); 22.V.1996, M. Simonelli et al. 388 (UPCB, VIC).

Espécie endêmica do Brasil, restrita aos estados de Minas Gerais, Rio de Janeiro e São Paulo (Cervi 1997). Passiflora tetraden é morfologicamente semelhante a $P$. actinia Hook, porém esta última sempre apresenta folhas inteiras e as brácteas são verticiladas e de tamanhos iguais entre si, enquanto em $P$. tetraden pode apresentar folhas superficialmente lobadas no ápice e uma das brácteas situa-se mais abaixo e possuindo um tamanho menor que as demais. Não há registros de P. actinia para o estado de Minas Gerais. As ilustrações da espécie podem ser encontradas em Vellozo (1831, fig. 91), Masters (1872, fig. 122 II), Milward-de-Azevedo \& Valente (2004, p. 372, fig. 2g-1), Milward-de-Azevedo (2007a, p. 77, fig. 3h-n), Mezzonato-Pires et al. (2013, p. 131, fig. 2e-f) e Moraes (2016, pág. 81, fig. 31j-n).

50. Passiflora trintae Sacco, Selowia 20: 22, Fig. 1, 2. 1968.

Trepadeiras herbáceas, glabras. Caules cilíndricos. Estípulas lineares, 1,5-2,5 × ca. 0,1 cm. Folhas com pecíolos 3,5-4,5cm compr., 4 glândulas sésseis; lâminas foliares simples, trilobadas, 3-5 $\times$ 4,5-8,5 cm, ápice obtuso, base cordada, margens serreadas. Brácteas ovaladas, $1-1,4 \times 0,4-0,6 \mathrm{~cm}$. Pedúnculos solitários, $2-3,5 \mathrm{~cm}$ compr. Flores $5-7$ $\mathrm{cm}$ diâm; tubo do cálice cilíndrico, 1-1,7 × 0,8-1 $\mathrm{cm}$; sépalas oblongo-lanceoladas, $2-2,7 \times 0,5-0,7$ $\mathrm{cm}$, aristadas; pétalas oblongo-lanceoladas, $2-2,5 \times$ $0,5-0,6 \mathrm{~cm}$; corona de filamentos 3 séries, duas séries externas filiformes, 3-5 cm compr., série interna capilares, $0,1-0,2 \mathrm{~cm}$ compr.; androginóforo $2-3 \mathrm{~cm}$ compr.; ovário fusiforme, glabro e glauco. Frutos e sementes não vistos.

Material examinado: Almenara, 28.II.2004, J.A. Lombardi et al. 5635 (BHCB, UPCB). Beliro, 13.II.2001, E. Tameirão Neto 3184 (BHCB, UPCB); 26.XI.1985, G. Hatschbach et al. 50173 (MBM). Grão Mogol, 13.XII.1989, J.R. Pirani et al. 12691 (MBM); 4.XI.1987, J. Codeiro et al. 
11469 (UPCB). Jequitinhonha/Pedra Azul, 9.III.1977, G.J. Shepherd et al. 4448 (MBM); 5.IV.2002, T. Jost et al. 428 (MBM, HRB). Rio Pardo de Minas, 3.II.2014, D.C. Imig et al. (UPCB).

Espécie endêmica do Brasil, restrita aos estados da Bahia e Minais Gerais, ocorre na Mata Atlantica e Caatinga(BFG 2015; Flora do Brasil 2020). Passiflora trintae pode ser confundida com $P$. mendoncaei, pois apresentam as flores de coloração purpúrea e tubo do cálice tubular, porém esta última apresenta duas glândulas nos pecíolos, enquanto $P$. trintae apresenta seis glândulas. As ilustrações da espécie podem ser encontradas em Nunes \& Queiroz (2006, p. 220, fig. 19e) e Vitta (2006, p. 10, fig. 1c-f).

51. Passiflora vellozii Gardner, Lond. J. Bot. 4: 103. 1845 .

Trepadeiras herbáceas, pilosas, tricomas glandular capitados. Caules cilíndricos. Estípulas ovaladas a oval-lanceoladas, 0,3-1,2 × 0,3-1 cm, margens glandular serreadas. Folhas com pecíolos 1,4-3 cm compr., 2-6 glândulas estipitadas; lâminas foliares simples, trilobadas, hastadas, ovaladas a oval-lanceoladas, 4-10 × (2,5-)3-8 cm, lobos ovallanceolados, ápice agudo a obtuso, base cordada, margens denticuladas em direção para a base. Brácteas ovaladas a oval-lanceoladas, 0,8-2,3 × 0,5-1,5 cm, bipinatipartidas, pinas terminados em glândulas. Pedúnculos solitários, 1-2 cm compr.; pedicelos 0,20,3 cm compr. Flores 4,8-6 cm diâm; tubo do cálice curto-campanulado a pateliforme, 1-1,2 × 0,4-0,7 cm; sépalas oblongas, 1,5-2,5 × 0,7-1 cm, aristadas; pétalas oblongas a oblongo-lanceoladas, 1,2-2,2 $\times$ 0,6-0,8 cm; corona de filamentos 3 séries, duas séries externas filiformes, $1-1,8 \mathrm{~cm}$ compr., série interna capilares, 0,2-0,4 cm compr.; androginóforo 0,5-1,2 cm compr.; ovário ovoide, hirsuto. Frutos bagas, globosas a ovoides, 2,5-4 cm diâm., hirsutas; sementes oblongas, 0,4-0,5 $\times$ ca. $0,2 \mathrm{~cm}$, testas reticuladas.

Material examinado: H.A. Weddell 1333 (P); 1816-1821, Saint Hilaire B2 2239 (P); 24.II.1838, J. Miers 4457 (BM); II.1892, E. Ule 2569 (B, C, F, US). Baependi, Toca dos Urubus, 29.XII.2004, F.M. Ferreira 917 (UFJF). Itabirito, 10.VI.1971, L. Krieger 10676 (CESJ). Ouro Preto, II.1892, Z. Sandsteinfelsen 2569 (MO).

Espécie endêmica do Brasil, restrita aos estados do Espírito Santo, Minas Gerais, Rio de Janeiro e São Paulo, ocorredo em Mata Atlântica (BFG 2015; Flora do Brasil 2020). Passiflora vellozii é morfologicamente relacionada com $P$. villosa, mas esta última é uma planta hirsuta, as brácteas são denteadas ou laceradodenteada e o ovário glabro, enquanto $P$. vellozzi é uma planta completamente pubérula, apresenta brácteas bipinatissectas, e ovário hirsuto. As ilustrações da espécie podem ser encontradas em Cervi (2000, p. 98, fig. 2) e Bernacci et al. (2003, p. 267, fig. 2e-g).

52. Passiflora villosa Vell., F1. Flumin. 9, t. 87. 1831.

Fig. 3g

Trepadeiras herbáceas, completa e esparsamente pilosas. Caules cilíndricos. Estípulas ovaladas a oval-lanceoladas, 0,5-1,5 ×0,3-0,7 cm. Folhas com pecíolos 0,4-1 cm compr., 4 glândulas longo-estipitadas; lâminas foliares simples, brevemente trilobadas ou raramente trilobadas, ovaladas a oval-lanceoladas, (3-)6-12 × (2,5-)3,5-8 $\mathrm{cm}$, lobo mediano geralmente mais pronunciado, ápice agudo a obtuso, base cordada, margens denteadas. Brácteas ovaladas a oval-lanceoladas, $0,8-2,5 \times 0,2-0,8 \mathrm{~cm}$. Pedúnculos aos pares, 1-2,5 cm compr.; pedicelos 0,3-0,4 cm compr. Flores 3-4,8 cm diâm.; tubo do cálice curto-campanulado a pateliforme, $1-1,2 \times 0,4-0,7 \mathrm{~cm}$; sépalas oblongas, $1,5-2,8 \times 0,5-0,8 \mathrm{~cm}$, aristadas; pétalas oblongas a oblongo-lanceoladas, 1,2-2,5 × 0,4-0,7 cm; corona de filamentos $2(-3)$ séries, duas séries externas filiformes, 1-1,8 cm compr., série interna, quando presente, capilares, 0,1-0,2 cm compr.; androginóforo 0,5-1 cm compr.; ovário globoso a subgloboso, glabro. Frutos bagas, globosos, 2,5-4 cm diâm.; sementes oblongas, $0,5-0,6 \times 0,2-0,3 \mathrm{~cm}$, com 3 dentes apicais, testas alveoladas.

Material examinado: Baependi, 29.XI.2004, N.M. Farinazzo \& F.M. Ferreira 917 (CESJ; MBM). EsperaFeliz, 30.III.1979, P. Occioni 8903 (RFA). Nova Lima, Morro do Chapéu, 23.X.1981, TSMG 777 (BHCB). Ouro Preto, 10.I.1942, M. Magalhães 1394 (BHCB); 6.XII.1988, M. Peron 494 (UPCB, RB). Rancho Novo, 13.IV.1933, $M$. Barreto 4526 (BHCB). São Roque de Minas, 25.IX.1995, J.N. Nakajima 1311 (UPCB, HUFU). São Tomé das Letras, 31.XII.2012, D.C. Imig 105 (UPCB, MBM); 31.XII.2012, D.C. Imig 106 (UPCB, MBM).

Espécie endêmica do Brasil, distribuída pelos estados da Bahia, Distrito Federal, Goiás, Minas Gerais, Rio de Janeiro, São Paulo, Paraná e Santa Catarina, em Caatinga, Cerrado, Mata Atlântica (BFG 2015; Flora do Brasil 2020). Passiflora villosa é morfologicamente relacionada com $P$. vellozii, porém esta última é uma planta completamente pubérula, apresenta brácteas bipinatissectas, e ovário hirsuto, enquanto, em $P$. villosa é uma planta hirsuta, as brácteas são denteadas ou lacerado-denteadas e o ovário é glabro. As ilustrações da espécie podem ser encontradas em Vellozo (1831, fig. 87), Masters (1872, fig. 110 II), Cervi(2000, p. 95, fig. 1), Bernacci et al. (2003, p. 267, fig. 2h-j), Nunes \& Queiroz (2006, p. 220, fig. 19f-g) e Vitta \& Pirani (2015, p. 35, fig. 2i). 
53. Passiflora watsoniana Mast., Gard. Chrom. 26: 648. F. 127. 1886.

Trepadeiras herbáceas a subherbáceas, glabras. Caules cilíndricos. Estípulas reniformes ou subreniformes, $0,5-1,5 \times 0,3-1 \mathrm{~cm}$. Folhas com pecíolos $2,5-3 \mathrm{~cm}, 2-5$ glândulas estipitadas; lâminas foliares simples, trilobadas, 3-6,3 × 4-8,8 $\mathrm{cm}$, lobos lanceolados, ápice obtuso, base cordada, margens inteiras. Brácteas setáceas, 0,5-0,6× ca. 0,1 $\mathrm{cm}$. Pedúnculos solitários, 5-6 cm compr.; pedicelo 0,2-0,3 cm compr. Flores 4-5 cm diâm.; tubo do cálice campanulado, $0,7-0,8 \times 0,2-0,4 \mathrm{~cm}$; sépalas oblongo-lanceoladas, 1,5-2,3 × 0,5-0,7 cm, aristadas; pétalas oblongo-lanceoladas, $1,3-1 \times 0,4-0,6 \mathrm{~cm}$; corona de filamentos 5 séries, duas séries externas filiformes, 1,5-2 cm compr., as séries seguintes filiformes, $0,5-0,8 \mathrm{~cm}$ compr.; androginóforo $0,8-1$ cm compr.; ovário ovóide, glabro, glauco pruinoso. Frutos bagas, oblongas, 5-8 $\times$ 4-7 cm; sementes ovaladas, $0,3-0,5 \times 0,2-0,3 \mathrm{~cm}$, testas foveoladas.

Material examinado: Januária, Serra das Araras, 19.IV.1973, W.R. Anderson et al. 9206 (UB).

Espécie endêmica do Brasil, ocorre nos estados de Alagoas, Bahia, Paraíba, Pernambuco e Minas Gerais, em domínio de Mata Atlântica (BFG 2015; Flora do Brasil 2020). Passiflora watsoniana pode ser confundida com $P$. amethystina, e diferencia-se pelo tamanho do pedúnculo, de até $5 \mathrm{~cm}$ compr., em $P$. watsoniana, e maior do que $5 \mathrm{~cm}$ compr. em $P$. amethystina. A coloração das flores também difere as especies, rosadas em $P$. watsoniana e violáceas em $P$. amethystina.

\section{Referências}

APG III - Angiosperm Phylogeny Group (2009) An update of the Angiosperm Phylogeny Group classification for the orders and families of flowering plants: APG III. Botanical Journal of the Linnean Society 161 : 105-121.

Arbo MM \& Espert SM (2009) Morpholgy, phylogeny and biogeography of Turnera $\mathrm{L}$. (Turneraceae). Taxon 58: 457-467.

Bernacci LC, Mezzonato AC \& Salimena FRG (2014) A new and threatened species of Passiflora section Decaloba (Passifloraceae) from Minas Gerais State, Brazil. Systematic Botany 39: 517-522. DOI 10.1600/036364414X680799.

Bernacci LC, Vitta FA \& BakkerYV (2003) Passifloraceae. In: Wanderley MGL, Shepperd GJ, Giulietti AM (eds.). Flora fanerogâmica do estado de São Paulo. Instituto de Botânica, São Paulo. Vol. 3, pp. 247-274.

BFG - Brazil Flora Group (2015) Growing knowledge: an overview of seed plant diversity in Brazil. Rodriguesia 66: 1085-1113.
Cervi AC (1986) Passifloraceae. In: Rizzo SA (ed.) Flora do estado de Goiás. Coleção Rizzo 7: 1-45.

Cervi AC (1992) Passifloraceae. In: Melo MMRF et al. (eds.) Flora fanerogâmica da Ilha do Cardoso. Vol. 3. Instituto de Botânica de São Paulo, São Paulo. Pp. 11-20.

Cervi AC (1996) Passifloraceae da região de Carangola - Minas Gerais, Brasil. Pabstia 7: 1-32.

Cervi AC (1997) Passifloraceae do Brasil: estudo do gênero Passiflora L. subgênero Passiflora. Fontqueria 45: 1-92.

Cervi AC (2000) Estudo das Passifloraceae brasileiras: o subgênero Dysosmioides Killip do gênero Passiflora para o Brasil. Estudos de Biologia 45: 91-115.

Cervi AC (2006) The genus Passiflora L. (Passifloraceae) from Brazil, species described after the year 1950 . Adumbrationes ad Summae Editionem 16: 1-5.

CNCFlora - Centro Nacional de Conservação da Flora (2016) Passifloraceae. In: Lista vermelha da flora brasileira versão 1 . Disponível em $<$ http://cncflora. jbrj.gov.br/portal/pt-br/profile/Passiflora saccoi $>$. Acesso em 13 setembro 2016.

Costa ECS, Nunes TS \& Melo JIM (2015) Flora da Paraíba, Brasil: Passifloraceae sensu stricto. Rodriguésia 66: 271-284.

Deginani NB (2001) Las especies argentinas del género Passiflora (Passifloraceae), Darwiniana 39: 43-129.

Farinazzo NM \& Salimena FRG (2007). Passifloraceae na reserva biológica da represa do grama, Descoberto, Minas Gerais, Brasil. Rodriguésia 58: 823-833.

Fontes AL, Fonseca RS, Bernacci LC \& Vieira MF (2013) Reserva Florestal Mata do Paraíso, Viçosa, Minas Gerais. Rapid Color Guide 374.

Feuillet C \& MacDougal JM (2003) [2004]. A new infrageneric classification of Passiflora L. (Passilforaceae). Passiflora: The Journal \& Newsletter of Passiflora Society Internacional 13: 34-38.

Feuillet C \& MacDougal J (2007) Passifloraceae. In: Kubitzki K (ed.) The families and genera of vascular plants. Vol. 9. Springer-Verlag, Berlin. Pp. 270-280.

Flora do Brasil 2020 em construção. Instituto de Pesquisas Jardim Botânico do Rio de Janeiro. Disponível em <http://floradobrasil.jbrj.gov.br/>. Acesso em 24 outubro 2018.

Gengler-Nowak KM (2003) Molecular phylogeny and taxonomy of Malesherbiaceae. Systematic Botany 28: 333-344.

Holmgren PK, Holmgren NH \& Barnett LC (1990) Index herbariorum. Part 1: the herbaria of the world. New York Botanical Garden, New International Botanical Congress, New York. PhytoKeys 5: 1-3.

Imig DC \& Cervi AC (2013) Passifloraceae. In: Cavalcanti TB \& Amaral-Lopes AC (eds.) Flora do Distrito Federal, Brasil. Vol. 11. Emabrapa Recursos Genáticos e Biotecnologia, Brasília. Pp. 57-89. 
Imig DC \& Cervi AC (2014) A new species of Passiflora L. (Passifloraceae), from Espírito Santo, Brazil. Phytotaxa 186: 292.

Killip EP (1938) The american species of Passifloraceae. Publication Field Museum of Natural History Botanical Series 19: 1-613.

Krosnick SE, Ford AJ \& Freudenstein JV (2009) Taxonomic revision of Passiflora subgenus Tetrapathea including the monotypic genera Hollrungia and Tetrapathea (Passifloraceae), and a new species of Passiflora. Systematic Botany 34: 375-385.

Masters MT (1872) Passifloraceae In: Martius CFP von, Eichler AW \& Urban I (eds.) Flora brasiliensis. Munchen, Wien, Leipzig. Vol. 13, pp. 529-628.

Mezzonato-Pires AC, Salimena FRG \& Bernacci LC (2013) Passifloraceae na Serra Negra, Minas Gerais, Brasil. Rodriguesia 64: 123-136.

Mezzonato-Pires AC (2017) Sistemática de Passiflora subgênero Astrophea (Passifloraceae): morfologia, palinologia e taxonomia. Tese de Doutorado. Universidade Federal do Rio de Janeiro, Rio de Janeiro. 285p.

Milward-de-Azevedo MA (2007a) Passifloraceae do Parque Estadual de Ibititpoca, Minas Gerais. Boletim de Botânica da Universidade de São Paulo 25: 71-79.

Milward-de-Azevedo MA (2007b) Revisão taxonômica de Passiflora L. subgênero Decaloba (DC.) Rchb. no Brasil. Tese de Doutorado. Universidade Federal do Rio de Janeiro, Rio de Janeiro. 243p.

Milward-de-Azevedo MA (2008) Three new species of Passiflora subgenus Decaloba (Passifloraceae) from Brazil. Brittonia 60: 310-317.

Milward-de-Azevedo MA \& Baumgratz JFA (2004) Passiflora L. subgênero Decaloba (DC.) Rchb. (Passifloraceae) na Região Sudeste do Brasil. Rodriguésia 55: 17-54.

Milward-de-Azevedo MA, Baumgratz JFA \& GonçalvesEsteves VA(2012) Taxonomic revision of Passiflora subgenus Decaloba (Passifloraceae) in Brazil. Phytotaxa 53: 1-68.

Milward-de-Azevedo MA \& Valente MC (2004) Passifloraceae da mata de encosta do Jardim Botânico do Rio de Janeiro e arredores. Arquivos do Museu Nacional do Rio de Janeiro 62: 367-374.

Moraes AM (2016) Passifloraceae Juss. sensu stricto no Parque Estadual Serra do Brigadeiro, Minas Gerais, Brasil. Dissertação de Mestrado. Universidade Federal de Juiz de Fora, Juiz de Fora. 108p.

Nunes TS \& Queiroz LP (2006) Flora da Bahia: Passifloraceae. Sitientibus 6: 194-226.

Sacco JC (1971) Contribuição ao estudo das Passifloraceae do Brasil V. Passiflora cerradense Sacco. In: III Simpósio sobre o Cerrado. Edgard Blücher, São Paulo. Pp. 212-214.

Sacco JC (1980) Passifloráceas. In: Reitz R (ed.) Flora ilustrada catarinense. Herbário Barbosa Rodrigues, Itajaí. 132p.

Silva EO, Santos JUM \& Dias ACAA(2013) Passifloraceae na área de proteção ambiental de Belém, PA, Brasil. Rodriguésia 64: 829-845.

Standley PC \& Williams LO (1961) Passifloraceae. In: Standley PC \& Williams LO (eds.) Flora of Guatemala. Fieldiana 7: 115-146.

Stevens PF (2001) Angiosperm Phylogeny Website. Version 9. Disponível em $<$ http://www.mobot.org/ MOBOT/research/APweb/>. Acesso em dezembro 2016.

Tokuoka T (2012) Molecular phylogenetic analysis of Passifloraceae sensu lato (Malpighiales) base don plastid and nuclear DNA sequences. Journal of plant research 125: 489-497. DOI 10.1007/s10265011-0472-4.

Ulmer T \& MacDougal JM (2004) Passiflora: passion flowers of the world. Timber Press, Portland. 430p.

Vanderplank J (1996) Passion flowers. MIT Press, Cambridge. $224 \mathrm{p}$.

Vellozo JMC (1831/1881) Passiflora. In: Flora Flumimensis 9. Tab. 70-95. A. Senefelder, Paris. Arquivos do Museu Nacional do Rio de Janeiro 5: 378-381.

Vitta FA (2006) Flora de Grão-Mogol, Minas Gerais: Passifloraceae. Boletim Botânico da Universidade de São Paulo 24: 9-12.

Vitta FA \& Pirani JR (2015) Flora da Serra do Cipó, Minas Gerais: Passifloraceae. Boletim Botânico da Universidade de São Paulo 33: 29-38.

$\uparrow$ In memorian ao Dr. Armando Carlos Cervi, orientador de mestrado da primeira autora e precursor deste trabalho. Graduado em História Natural pela PUC-PR, fez especialização em Morfologia Vegetal, pela Universidade Federal do Paraná, Doutorado em Taxonomia Vegetal pela Universidade de Barcelona (Espanha), e Pós-Doutorado pela Universidade de Barcelona (Espanha). Professor Titular da UFPR, onde ao longo de muitos anos contribuiu com a ciência voltada a taxonomia vegetal especialmente da família Passifloraceae. Por onde passava, distribuía conhecimentos e conselhos, um grande mestre. Adorava contar histórias e era extremamente apaixonado por sua família, destacava sempre em suas histórias a Kiki (Maria Francisca), sua primeira neta a quem fez uma homenagem com uma nova espécie de Passiflora, Passiflora kikiana Cervi. Para nós, eterno professor Armando. 